


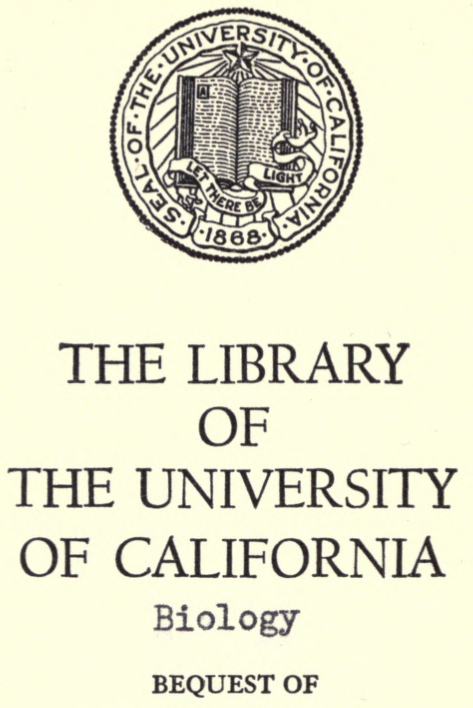

Theodore S. Palmer 
Dr. Yhasdone S. Parnuer.

Alurayp youn fuend

fune 16, 1922.

Viedorkwtehin 






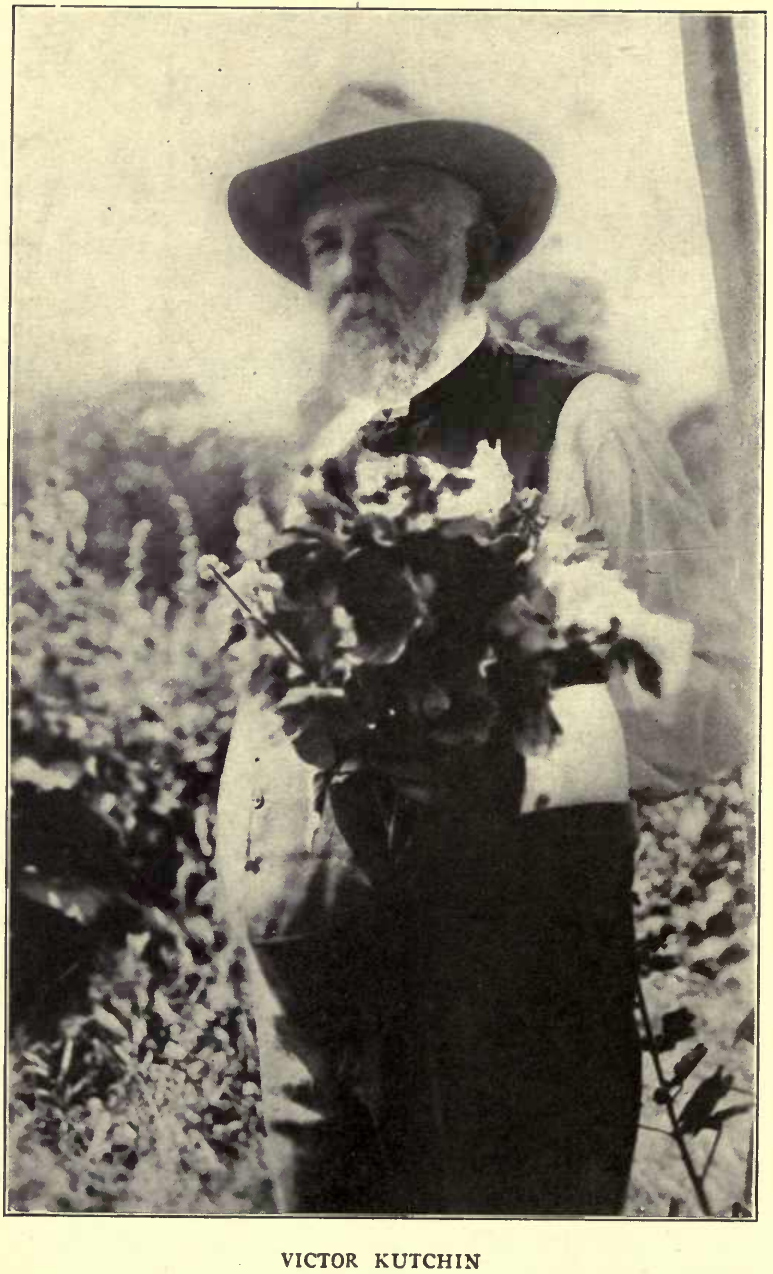




\title{
WHAT BIRDS HAVE DONE WITH ME
}

\author{
BY \\ VICTOR,KUTCHIN, M.D. \\ A BIRD-LOVER
}

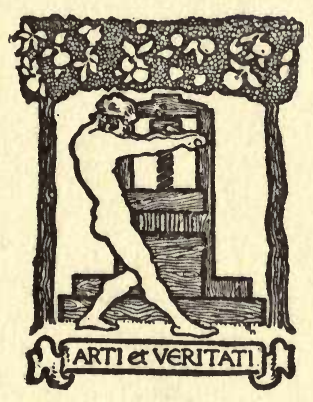

BOSTON

RICHARD G. BADGER

THE GORHAM PRESS 
COPYRIGHT, 1922, BY RICHARD G. BADGER All Rights Reserved

Made in the United States of America The Gorham Press, Boston, U. S. A. 


\section{TO}

\section{GENE STRATTON-PORTER}

A true Nature-lover, whose interest in birds is not in anatomical specimens, but in creatures very much alive, wonderful for beauty, song and wings, that have spiritual uplift in them for human beings; this little volume about live birds is gratefully dedicated. 



\section{CONTENTS}

CHAPTER

PAGE

I VIRGIN SoIL • • • • • • • • •

II Mr. Turveydrop and His Foreign Cousins • • • • • • • 2 I

III Motherless Babies . • • • • . 3 I

IV The Keeper of the Spring-House . 42

V Wings, Wings, Wings • • • • 52

VI Pirates . . . . . . . . . . 63

VII AN Old Log That Was Bewitched . 72

VIII Nothing So Silly as a Goose • • 83

IX A Dish of Robins • • • • • . 94

X Mr. Chickadee . . . . . . . 105

XI The Song and the Singer . . . . II9

XII The Love Element in Bird ProtecTION • • • • • • • • • 132

XIII Mr. ESAU . . . . . . . 150

XIV StUpidity Street . . . . . . 160

XV JaYs and Crows . . . . . . . 175

XVI BIRds' Courtship and Marriage . 193

XVII Last Year's Bird's Nest . . . . 207

XVIII A SaINT Bartholomew of Birds . . 221

XIX Some Invisible Defenders . • • 237

XX Getting Acquainted . • • • . 246

XXI The Unknown Pathway . . . 26I 



\section{WHAT BIRDS HAVE DONE WITH ME}





\section{What Birds Have Done With $\mathrm{Me}$}

\section{CHAPTER I}

VIRGIN SOIL

Alice Cary, in her order for a picture, started out by asking a painter, "Has your hand the cunning to draw shapes of things that you never saw?" On the face of it, that request is scarcely less appalling than the demand in olden times for the interpretation of a forgotten dream. Later on, we find that she hoped to make the artist see the desired picture with her eyes, not his own. Using words for pigments, she is very successful in reproducing her memory picture, but what the painter saw was unfortunately never put upon canvas to constitute an object lesson of what a blur and daub a picture must be where the artist is attempting to paint something that he never actually saw himself.

The libraries and art galleries of the world are 
lumbered up with spoiled reams of paper and ruined squares of canvas upon which blind men have attempted to make those who have eyes see what they never saw themselves. Shakespeare, strangely enough, in his closing of "The Tempest," assured the audience that the actors are spirits, the play, a baseless fabric, the whole setting of the stage, an unsubstantial pageant that would leave not a rack behind.

The old preface was a kind of declaration of superior wisdom on the part of the author who found it expedient to call his audience to look over his shoulder while he explained the profundities of his creation. Nevertheless, explanations often require further explanations, and so on, like a nest of Chinese boxes that turn out, finally, to have nothing in the last box. On the other hand, real things may be safely trusted in the hands of real people, and the rest do not count.

To one who sees everything as in a picture, whose mind is actually photographic, memory corresponds to a film that may be developed into permanent pictures, or rejected and thrown away like seed that will not grow. With films developed into permanent pictures, I shall utterly fail unless I have the cunning to put them together and make them something like moving pictures; make you, in fact, see a real forest with trees that sway in 
the wind, whose boles are being attacked by actual wood-choppers, who make the chips fly and the giants tremble convulsively and go crashing to earth with the boom of cannons. This, after innumerable repetitions, is followed by the smoking hell of flames that out-rivals the light of the sun, and literally burns a great hole in the night. This precedes the coming of the mighty breaking plow to turn up the virgin soil. It is drawn by four yoke of oxen, following after each other-a great centipede walking with many legs. Alas, like the virgin soil turned up by the first furrow, the mind also must be virgin soil in order to have such a picture stamped indelibly upon it. Only the mind of a boy, waxed to receive and steeled to retain, would be likely to catch out-line and minutix, light and shadow, central figures and back-ground, newness and age, and, robing all in the royal purple of a first experience, hang it in a temple not made with hands; a memory picture of such immortal youth that, in comparison, the baby faces of the Sistine fresco would seem dim and old.

"Here they come, Here they comel" shouts the small boy, "Better get out of the way if you don't want to get run over;" That is not a pistol, that's the cracking of a whip! "Get up, Buck, Get up, Brin; Get up, Mose; Get up, Pete; Get up, Tom; Get up, Jerry; Get up, Bob; Get up, 
Harry;" almost sings the driver. Then the plow man shouts to him, "Why the devil don't you keep those leaders in line? Do you think I'm marking out a circus ring?" Straight to the flag; "There, that's better!" and away they go. The small boy is in pursuit and will never forget that first furrow. The soft, cool earth at its bottom seemed to have a kiss and caress for his bare feet at every step. Round and round they go, the share of the great plow, sharp as a knife, cutting off roots bigger than his leg, just like they were cheese. But sometimes they are too big, and the driver goes frantic, and running along the line of straining oxen, whipping, shouting, and swearing, he finds it no use, they have to leave that particular root. Sometimes the chain will get caught on a stump and the big plow will fairly jump out of the ground, the plowman dropping the handles and dodging just like he was afraid of it.

The small boy whoops and shouts himself hoarse, feeling that he is taking part in the grandest game ever played on earth. They plowed six furrows around the great field by noon, and then turned the cattle out to graze with the yokes on, so they would not stray too far. Then they take off the share of the plow that they call the lay, and proceed to sharpen it by putting it in a furious fire until it is red hot; then, holding it with pinchers on a big piece of iron, called an anvil, 
they pound it, and hammer it till it makes your ears ring. From where they stand, the small boy can see all over the field, and for the first time he notices that the furrows look like the paper border on his own room at home. The yellow border around the green field looks quite pretty, and he wonders if the birds would enjoy it if they never did any more plowing, but just left it as it was. He does not believe the black-birds that swarmed around him as they followed the plow, gobbling up every living thing would, because they were too greedy to notice anything but something to eat. He had been too busy before to give more than a passing thought to the countless forms of life brought to light by the plow. He had not sup. posed that so many things lived under ground. Why did they do it? He would ask his father about it, and he must not forget to ask him why each new furrow lapped over on the edge of the last one as if it had to be held down.

After dinner, he propounded these questions and was told that the earth was the real home of every thing; that all that lived had come forth from it and would ultimately return and slumber in its bosom. That with regard to the furrows, they would doubtless remain where they were if not held down, because so far they had not run away, and they probably had been turned over again and again; perhaps by a plow ten times as 
14 What Birds, Have Done With Me

big as old man Hill's, drawn by elephants, or a little plow made out of a single piece of wood drawn by a buffalo or a donkey, and driven by a man practically naked. The small boy looked a bit puzzled, but said, "Yes, thank you, sir," and started to run to catch up with old man Hill, the plow man, and Pete, the oxen driver. The latter now had a new cracker on his whip. As a matter of fact, the urchin had not understood a word that his father had said to him, but he was conscious of a vague, troubled feeling, and when the plow started again, he began to scrutinize the living things turned up, to see if among them all, there were any who would make good play-fellows if he had to come and live in the ground with them.

If there is such a thing as the fascination of repulsion, it would go far to explain the small boy's increasing interest in the creatures from the underworld, sent scurrying for safety in all directions, or left helpless in the bottom of the furrow by what may have seemed to them something a bit like what an earthquake is to us. Ralph Waldo Emerson emphasizes the fact, that "we see what we look for," and each thing that he had noticed in the fore-noon was multiplied by ten in the afternoon. Ants, worms, grubs, beetles, swarmed -and one had a thousand legs, as sure as you are alive. He found only two things that under any 
possible circumstances could have been nice neighbors, - a big white thing that dirt could not make dirty, appealed to him on account of its utter helplessness, - and a beetle colored like the rainbow, from which it must have fallen.

The king of the purple grackles had clearly sent out into the high-ways and hedges, and bidden all his kith and kin and subjects of every kind, to a great supper that was waiting, and was little short of royal in its abundance. They were all there, and simply took possession of the earth and the fullness thereof,-dignified, and almost stately, but not too much so to make the most of their opportunities. It is in the nature of feasts to make outside folks especially conscious of hunger, and so the robin and the blue-jay came for their share; and after them, slipping from cover into the furrow, and gone like a sunbeam, was a shy brown bird that played the part of Ruth among the corn.

It was a thoroughly tired urchin that dragged leaden feet upstairs to bed that night, and found the dream-land ship with sails unfurled awaiting him. It "geed" and "hawed" a time or two and he never knew when it passed the harbor bar and glided away into the great ocean of forgetfulness.

The dawn wind had scarcely commenced to toy with the freshness of the June morning, a fresh- 


\section{I6 \\ What Birds Have Done With Me}

ness augmented by great drops of dew that at sun-rise would, for a moment, reflect the sun and die in a blaze of glory. Before dawn, the small boy was up and dressing on his way down stairs to be on hand to help Pete Jackson retrieve the oxen from the fastnesses of the great swamp, that lay to the northwest. It was quite certain that they would go in that direction for water, and the lush grass abounding there would meet the requirements of hunger, and weariness would circumscribe their straying to narrow bounds. With a rain of dew shaken by the wind from every bush and tree, and rank marsh grass dripping with water, our sturdy urchin was soon wet to the skin,- literally didn't have a dry thread on him. But he counted this all joy, and waded shallow pools, floundered through deep mire, and would have whooped and shouted with delight, had he not been afraid of frightening his friends, the birds. In countless numbers, to the right and left of them, in front and behind them, strange calls and rival songs kept him alert to the teeming life of the wilderness. Anxious to see and hear them all, he was very, very far from realizing that it would take a life-time to come to know the life history of a few of them, well.

Bringing the cattle out of the swamp on the edge of the highlands, his real education in bird lore commenced in earnest. An unusually stupid 
brute of an ox that Pete was clubbing along, instead of going around a brush pile on the edge of an old logging road, blundered through it, sending a mother quail and her callow brood into the road at their feet. The mother gave one note of warning and the baby quail neither ran nor flew, but simply vanished before their very eyes. The small boy was sure that the ox had stepped on the mother, as she was turning somersaults rather than running, so he started after her like a flash, and in a minute had her in his hands. Pete, convulsed with laughter, came to meet him and examining the bird found she had lost the first joint of every toe, - they probably having been frozen off. What had tickled him so much was to see the fool thing trying to get them to chase her, when she was so "gol-fired" lame that their slowest ox could out-run her. He then, in reply to the small boy's question, "Why did she want us to chase her?" explained the world-old maneuver of certain mother birds to attract human creatures away from their nests, and furthermore puzzled the small boy by the statement that a quail, if she wanted to, could order her chicks to turn into dead leaves, - and they did it, too. While the explanations had taken place, the lad, holding the mother bird in both hands, had been cudgelling his brain for a name for her. When it came, it came like a flash,- "Good Mrs. Stumpy"; 
and he whispered it softly to himself as he almost reverentially put her on the ground, and saw her vanish into the under-growth.

Next morning when they went after the cattle, and for many succeeding mornings, little hands scattered wheat along the logging road, for a wild bird that had both a local habitation and a name.

Before the end of the week, in which the Lord sent him the quail, and he tasted of the tree of knowledge at almost the same instant, -isn't that a fine mixture?-he did something that goes to prove that a little knowledge may be a very dangerous thing. The breakers were now on the last five acres. His interest had not flagged and he was still in pursuit of the plow and the oxen. The grackles had come to regard him as part of the out-fit, and Pete and old Hill proved themselves to be fine play-fellows. When a thing happened that came very near sending a foolish little boy to dwell with those things that live under ground, where his father had told him everything would finally return. That he escaped being trampled to death in the virgin soil in which he had so delighted, by the very oxen he had driven and petted, both Pete and old Hill agreed was nothing short of a God's miracle. Swinging around on the northeast corner where there was a little sand knoll, right under the feet of "Bob" and "Harry," 
who were half broken, flighty steers, a gray bird, a whip-poor-will, started, more gracefully to be sure, to enact the rôle of "Good Mrs. Stumpy." One glance at her, and keeping his eyes on the spot where she started her gyrations, the small boy dashed under the feet of the cattle, to save the nestlings that were surely going to be trampled to death. Doubtless only catching a glimpse of him, and possibly regarding him, when on all-fours, as some new kind of wild animal, the steers began to kick and plunge in the utmost terror, and crowding the leaders out of the furrow, the two head yokes swung around toward the plow, and what had been a quiet, orderly breaking team became an excited and unmanageable bunch of wild cattle; "beginning to mill" with a small boy out of sight and in the center of them. According to their stories, both Pete and old Hill were the rescuers, but whoever did it, pulled out between trampling feet, a very dirty and tousled youngster, holding a bird in each hand, and wonder of wonders, with the exception of some slight bruises, not hurt at all. He had given fear no place in his mind, entirely taken up with the thought of rescuing the helpless, and after all the scolding and the final order to keep away from the breaking, not then nor ever afterward, could he feel, or would he admit, the slightest regret for what he had done. 
Only once did he disobey his father's order to keep away from the breaking. At an early hour the next morning, he hurried out to the field to see for himself if the mother bird had found the young at the foot of a near-by stump where he placed them. Joy of joys, there she was, brooding them just as though nothing had happened. For several days, the lad went about as if he had something on his mind, and one evening after bidding his mother good-night, he returned, and lifting a puzzled face to hers, asked, "Mamma, does a fellow have to be a mother before he can understand how Mrs. Stumpy and Mrs. Whippoor-will feel, when they ask folks to come and kill 'em if they will just leave their babies alone?" She had at first smiled, but only for an instant, then she gathered him into her arms with unwonted tenderness, and said tremulously, "I guess not, my boy, my little boy!" 


\section{CHAPTER II}

MR. TURVEYDROP AND HIS FOREIGN COUSINS

That beauty is in the eye of the beholder, is a half truth, and is a part of a universal law that makes a mental condition, the measure of external influences upon us. Every artist knows that fifty per cent of the effect of a picture is in what may be termed background. A painting of Liberty enlightening the world, whose background is a city market, must of necessity be a failure for the subject demands, as background, the ocean and the sky.

Now, it is equally true that we will fail to understand the influence of a flock of birds upon the mind of the boy, unless we retrace his steps far enough to acquaint ourselves with the circumstances in which the secret of his mental condition lay hidden, when he first beheld them. Between the age of four and five, he lived for one year in the country, then three years in the city, hating it all and longing to get back home-back to nature.

Then the return. No angel with a flaming 
sword at the gate, and the gate wide open for any one to enter in and take possession. For four weeks he believed himself in the Garden of Eden, and as a mother hen will try to stretch her wings to cover every thing in sight, so the wings of his love yearned to gather every living thing beneath them. Joy, joy, joy beneath the tender light of a new heaven, and on the warm palpitating breast of a new earth, - and then came death and all his woes. Is the object of life, to teach by experience? Perhaps, for certain it is that we never half know a thing till we have thus learned it. Many a funeral he had seen in the city, and once, visiting a boy who lived near a cemetery, they, with a few neighboring boys, had spent half a day playing I Spy and hiding behind tombstones, but death never really came home to him till he looked upon the stark and stiff bodies of some little pigs that had actually died in his own Eden. Between the house and the barn, early one morning, he had met his father, who paused long enough to say, "Black Sue has eight babies. Have you seen them?"

He might have said more, but the boy did not give him a chance. He was off for the sty, like a race horse, and in a moment came staggering back, dumb with horror. He had almost run over them, for they lay outside the sty all in a row-no cuter or more innocent babies under heaven, and all 
Mr. Turveydrop and His Foreign Cousins 23 quite dead. "No siree," he wouldn't cry. They would think him a fool if he cried over dead pigs, and never understand that it wasn't over the pigs, but was because he had just learned that it was possible for things to die in Eden. $\mathrm{He}$ and Sid took them over to the sand hill and buried them in eight separate graves; but toward night, when the boy thought about it, it seemed cruel to have separated them in death, so he got Sid, and they went back and dug a single grave-it was easy digging - and, lining it well with dead leaves, they snuggled them up together and covered them well with leaves, then the dirt; which was all a fellow could do.

Three days after this, he returned with his mother from a visit to the hated city, to find that his yearling heifer, Rosie, Cherry's calf, was dead, and his brother and the hired man had just skinned her, and were about to bury her on the sand hill where he and Sid had buried the little pigs. He ran to the barn-he had scarcely believed it could be true, but perhaps it was-but when he got there, he could not recognize the ghastly thing that lay there, with a chain around its neck, whose glassy eyes had in them no look of recognition. He followed the team that dragged the body beside the hole in the ground, into which they rolled it, in a hurry, jumping on the feet to bend them down so they would not stick out of the dirt when 


\section{What Birds Have Done With Me}

the hole was filled up; all the time laughing and talking about a dance that had taken place the night before. He declined to ride one of the horses, so they each mounted one and rode away, and left him. If he could have cried it would have been a lot better. He had had to battle with himself not to cry over the little pigs, but this loss left him dry-eyed and staring. There really had been a witchery about Rosie, in life, that possibly went a very little way to strengthen the old classic myth that Dido was actually turned into such a Heifer. Over all his domestic pets, she had reigned supreme. He did not refuse his dinner, but refused to wash his hands and face. 'Way back in his subconsciousness was a vague feeling that for him to be too clean, when she was smothered with dirt, would be a kind of disloyalty. Then, for a few days, loyalty to her made him welcome every dirty job about the place, and sincere grief had the effect of transforming a naturally cleanly little fellow, into a very dirty and unkempt one. In a nut-shell, here is what he had in his mind; he had learned in Sunday school that man was made out of the dust of the earth-it must have been mud or it would not have stuck together-in death, we go back into the dirt; what's the use to keep clean?

This represents his condition of both mind and body, on that May morning when he saw his first 
Mr. Turveydrop and His Foreign Cousins 25

flock of cedar Waxwings, among the blossoms of the wild crab apple trees, along the drive. They were a revelation of beauty and a rebuke to the unwashed and unkempt of the human family. In a wide sense, they were of the earth, but not of the dirt. He could not describe, he could only feel. Later on, he might have said, "Architecture has been called 'frozen poetry,' and my first glimpse of them made me dimly understand that I was looking upon incarnate poetry-They were the living, breathing spirit of harmony that is back of all musical expression." That they were feeding upon blossoms gave him a feeling that they were scarcely of the earth, surely not earthy of the earth. Other birds were covered with feathers; these were robed, uniformed, appareled by a master hand. Compared to them, many other birds were frumps, and even a gorgeous red and green parrot, little more than an Irish woman out for a holiday. So far as clothes went with them, every day was Sunday, for they wore their best three hundred and sixty-five days in the year, and like the smile of Optimism, they were as near perpetual as anything can be in a world of change. Being convinced that they were going to remain, he did not, but made a sneak for the kitchen and scrubbed his hands and face, combed his hair, brushed his clothes, got a straw hat that did not have a hole in the crown, and having done 


\section{What Birds Have Done With Me}

his best to make himself fit for polite society, he went back.

Years afterward, on a drowsy Sabbath day, he found himself listening to a frowsy little parson droning over a sermon from the text, "Keep yourselves unspotted from the world," and sweeping the window from the central blue of illimitable space, came the same old crab apple tree, where he had seen them first, and the identical flock of Waxwings, and he smiled to himself as he thought, "Any one of you smug fellows could give this poor little human, spades and trumps, and beat him in a sermon on this text, for at least you would look the part." One of the first reader lessons in life they were created to teach, they had thus neatly delivered to the boy, and he had made a personal application thereof, with soap and brush, and was now back for a second reader lesson. He did not have long to wait. The second reader class, and he was it, was ordered to take up the study of certain wax figures, representing deportment.

That a certain thing has been done in a certain way, time out of mind, is no reason that it should be continued; neither is there any sense in not trying a thing, simply because it never has been done. In the antiquated, rutty schools, in which humanity in its youth is guarded from learning any thing about the wonder world in which it has its being, it is customary for one individual to 
teach a class, but with the Wax-wings, to whom owls might go to school to their considerable profit, this is all reversed, and the class teaches the individual. Lady Clara, we have guessed your secret; we know where you got that repose that stamps the cast of Vere de Vere. To the Four Hundred of New York, we send this challenge: in a contest on Deportment, we will wager a hundred to one, and enter four Wax-wings against your entire bunch, and if you are not beaten, in addition to the loss of our wager, we will throw Turveydrop et al. into bankruptcy. We are not afraid of being beaten, for with the Wax-wings, deportment is a fashion and a passion; and if you must know it, a trust that can never be dissolved, by any court lower than the Supreme Court of the Universe. Long years afterward, when the boy had grown to manhood, and had married and had a boy of his own, during an Easter vacation, he took him down to Mill's swamp in a search for early spring Migrants, and the first birds to be encountered were a flock of twenty-one Waxwings, who are winter residents with us. They were, as always, on dress parade, and quite as bright and shining as the sun. Don't think me sacrilegious if I say that it was Communion Sabbath with them, for I don't mean it in either a religious or an irreligious way when I call attention to one of the most curious customs in the 
bird kingdom. The bird at the head of the line will pass a worm to his next neighbor, and he to his neighbor, till it has made the rounds of every bird in the flock, and has been returned to the one whose find it was, who proceeds to partake of it in a slow and sedate and decorous fashion, calculated to delight the heart of Dr. Fletcher. On higher ground, not twenty feet from the gaunt elm on which they were perched, the man and boy were having something like an interview with the birds, and the man was curious as to the effect of it on the mind of the boy. He did not have long to wait; in the flippant style of the average college youth came the comment. "Dad, don't you think these birds awfully stuck on themselves?" "Perhaps," came the rejoinder, "but in an age when misrule is the rule, rather than the exception, and Flippancy with his cap and bells marches through the land, past the seats of the mighty and up to the very throne of God, it's high time for us to learn a needful lesson of a bird that can always be trusted to do things decently and in order." There was a merry twinkle in the young fellow's eyes as he put his arm almost caressingly on his father's shoulder, and said, "I wanted to get a rise out of you, and that was the reason I threw the bait."

The Bohemian Wax-wing, a first cousin to the Cedar Wax-wing, is a cosmopolitan fellow, and his 
Mr. Turveydrop and His Foreign Cousins 29 visits are few and far between, but unlike angels' visits, they were formerly thought to presage war, pestilence, and famine-though, of course, it goes without the saying that in reality they had no more connection with the coming of such public calamities than the striking of your grandfather's clock. Mysterious and unusual things in the minds of people who haven't a thimble full of sense, always spell evil or devil. In later times, the Bohemian Wax-wing has been called the Seven-year Bird, but his ways are too erratic to be held down to human observation.

Not so long ago one of these birds of mystery gave up his life at the hands of a tender hearted old man, whose eyes grow dimmer, day by day; and in spite of the fact that it was an accident, the ghost of the dead bird is likely to follow him to the very end of life's journey. Every body knows what a pest the English sparrow is, and it had grown quite unbearable to the man. It could not be kept out of his Martins' house, it ate the food he provided for his winter birds, and fairly swarmed about an old cedar hedge not four rods from his office window. One day, quite forgetting all the lessons on deportment taught him by the Cedar Wax-wing, he lost his temper, and taking a gun, that he had not fired for years. he stepped to the door and fired into the hedge alive with English sparrows. Only one bird fell, 


\section{What Birds Have Done With Me}

and when he picked it up,-Oh, cruel spite!-it was a Bohemian Wax-wing: he, the last of all men on earth had reduced this rare and beautiful thing to supper for a cat, or a bit of carrion, the day after. That was unbearable, and without the least knowledge of what final disposition he was to make of it, he sent the body to a neighboring town to a taxidermist to be mounted. What a queer notion it is, that to some extent is in us all, that penance of one kind or another will help us to right a wrong, or correct a mistake. Acting as an attorney for all birds, he gave an earnest appeal to a large audience of school children to spare the birds, and not till on his way to the station and in front of the shop of the taxidermist, did he remember that it was here where he had sent the Wax-wing to be stuffed. He only had a moment, and acting on impulse he ran in, paid for the work, took out his card across which was printed in heavy type, "A friend of the Birds," and above his name wrote, "Killed by the donor January 13, 1913," and ordered it sent up to the School Collection of stuffed birds. Even after he had thought it over, he said to himself, "Yes, I richly deserve to have Mr. Turvey-drop's foreign cousin announce to all those children that I am a hypocrite," but after sleeping on it, he whispered to himself, on waking, "Being a Bohemian Wax-wing, perhaps he will make the announcement in French or German, and not in English." 


\section{CHAPTER III}

\section{MOTHERLESS BABIES}

Adolph Buzze was a Canadian wood-chopper, the only one left of a gang of his country-men who had helped denude the township, where the small boy lived, of the primeval forest; all the rest had drifted north and westward on the skirmish line of advancing settlement. To the small boy, Adolph became a guide, philosopher, and friend, and to him, he owed all his boyish knowledge of wood-craft. Born in the woods, always living in the woods, with eyes of wonder for every thing passing about him, his knowledge of woodfolks and wood-land ways was remarkable; now add to this, wonderful gaity, cheerfulness and perpetual laughter, and you have a personality calculated to take captive the heart of a child. His limited knowledge of English, added to, rather than detracted from, the charm of his conversation. Here are a few examples. Pointing to the criss-crossing of all manner of wild animal tracks in the snow, he would say at the end of a ripple and laughter: 
32 What Birds Have Done With Me

"Now, watch ze me read primer book in right tune," and he would unravel the tangle. Again, pointing to where a fox had made a long leap; "He say Adolph go buy more long leg." A duck's track would call forth this, or something like it; "When I try fly, fool like duck walk."

What he did not know about every living thing in the wilderness, the small boy did not think worth knowing. He was always eager to initiate his pupil into new mysteries,-even to the eating of a rye-bread sandwich, with frozen ants between the slices,-followed with shouts of laughter that woke the echoes, when he got a glimpse of the small boy's face, after swallowing the first mouthful. How can I convey any adequate idea of the perpetual delight of Adolph's cabin, dug into a sharp southern slope, with only two logs and the slope of its roof to mock at the north wind that went howling by in impotent rage? Lying on a bear skin, of a winter night, before the pulsating red glory of blazing logs, listening to Adolph's fiddle that told its own story of life in the woods, from the earliest chirp of half-awakened birds to the raucous screech of a catamount; music so wonderful that it fairly sent a thrill of swaying motion up among the skins of animals hanging near the rooftree of the unceiled room. To this, add marvelous jig dancing, French songs without number, and stories without end, 
about the old smooth bore rifle with which his grandfather had killed a whole tribe of Indians, single-handed, up in Canada, - not to mention a thousand elk, a thousand bear, a thousand caribou and buffalo, lynx, and wolves, more numerous than the stars in the sky. Swans, geese, ducks, partridges, pigeons, squirrels, and rabbits, he himself had gathered in, in numbers beyond the drops of water in the ocean. Wonder of wonders, it was with this almost sacred gun that Adolph taught him to shoot. The instruction was very excellent, "Hold ze gun down, bring ze gun up, shoot ze quick." The world nearly went topsyturvy when one day, meeting the little Frenchman with a load of wood, beneath which his old wagon had gone to pieces like the "wonderful shay," he said to him,

"Ze tell father, I trade ze rifle for ze green wagon. I even trade quick."

He never knew what he said in reply, but studying a Sunday school lesson that night, that happened to be about Jacob and Esau, he had a clear vision of what Adolph had offered to do; trade his birthright for a mess of pottage. When Adolph had made the proposition, he had thought him mad, and had not even mentioned it to his father, and he could scarcely believe his ears at dawn the next day, when he heard Adolph's voice in the yard, talking trade with his father. 


\section{What Birds Have Done With Me}

He heard him say, "Ze boy shoot ze gun good; good gun make ze good man. No draw chip with ze gun, trade, draw ze chip with ze wagon."

The small boy let no grass grow under his feet getting down stairs, but before he got there, the trade had been made. Adolph had traded his birth-right for the miserable, worn-out, old democrat wagon. Shrieking after Adolph that he could shoot it whenever he wanted to, when his father handed him the gun, he hugged it to his breast and made for his room-literally with a heart too full for utterance. Driving a couple of nails in the wall at the foot of his bed, he hung the gun where he could see it the last thing at night and the first thing in the morning, and it strangely supplemented the influence of "Anderson's Travels in Africa." Like a witch on a broom-stick, the small boy rode that gun through the darkest corners of the Dark Continent, and became a killer compared to whom Samson with his ass's jawbone was superseded. In his dreams, he shot up the world and all things therein, and like Alexander, wept that there were no more worlds to shoot up. The dawn's first flush and the last red banner in the evening sky, stood as marking the place where rivers of blood flowed. It was a lucky thing that the owner of the "Green Book," "Anderson's Travels in Africa," did not come to claim it, especially had he not been willing to take a 
small boy as well as the book, for he could scarcely have separated them. There must be some scientific, some psychological explanation of the effect of this old gun and the bloody account of killing big game in Africa, upon the mind of a naturally tender-hearted little chap. Without at all claiming to be a "Daniel come to judgment," here is a possible explanation. In every human heart is a desire for conquest, dominion; the gun gives us dominion over savage nature, - the power of life and death-the very attribute of kings. Add to this, the joy of the chase, a reversion to a savage ancestor and the universal lust to kill becomes less mysterious. There being no elephants, or lions within range, he had to content himself with the smaller things that the forests of his own country afforded, insignificant though they were. The first time he shot the head off a red-winged blackbird, flaunting on a cat-tail, a hundred yards away, cutting it away with a bullet, he seemed to grow a foot; eleven gophers with ten bullets, put him in the ranks with "Simon Kenton," that grand Indian fighter who never missed. The shooting of Abe Brulley's sheep-killing dog, at twenty rods, taken red-handed, so to speak, and he had conquered the earth and must now turn his attention to the sky for worlds to be subdued. Once more, he turned to Adolph for help.

"Want learn shoot on wing? Easy 'nuf. Hold 
36 What Birds Have Done With Me

gun under, bring gun up, shoot ze quick. Thousan' misses tell how fast each bird go quick. Easy 'nuf."

So far, the old smooth bore had been used as a rifle only, not with fixed ammunition, thank you, but powder from a flask, a piece of muslin for a patch, and bullets run from spoons that his sisters someway lost in setting the table. A half day's work for Culver, hoeing corn, and he had ammunition for wing-shooting that ought to last a week.

Two of their colts had wandered away and were with a band of neighbors' colts down at Hamilton's Point. The thought of the way they might be suffering touched a tender spot in the small boy's gizzard, and he was almost tearful as he begged his father to allow him to go and salt them. He likely would have wept had his father not given his consent, for if the truth must be known, he could not wait another day to try wing-shooting. The gun was already hidden in a fence corner out near the little woods, for his father had clearly repented of his trade with Adolph, and had shown himself strongly antagonistic to his son's evident ambition to become a mighty hunter. On one point, he was inflexible, no wild things must be killed in the breeding season, hence the gun in the fence-corner. Indeed, there are few things as rare as a day in June, 
and never had a brighter one dawned, to make glad the earth. If the small boy hadn't had the gun, perhaps he wouldn't have felt so much like flying, but if it were the cause of that wild exuberance, it held it in check by its own weight, that pretty effectually kept his feet on the earth. Only one more field to cross, and he would be out on the Point, over which ducks flew between the Lake and inlet, and he would have a try at them, and get them, too, and people would say of him as they said of Simon Kenton, "Our hunter never misses." No, that was almost too much to hope,- that he could ever really gain such deathless fame. There had been a law-suit over this land, and the previous year it had not been cultivated at all, but had grown up to weeds, higher than his head. Suddenly, a great bird got up almost at his feet. It seems as though the little Frenchman is at his elbow telling him what to do, and he does it like a flash, and down comes the dead thing - not four yards away. Yes, it was like Kenton, he, too, was destined to have that glorious reputation, "Our hunter never missed." But what are these gray shadows at his feet, living things turning into dead leaves, as Pete Jackson had told him Baby Quail could. All this he sees out of the tail of his eye, as he rushes to gather up his prize. A Prairie Chicken,not bad for a first wing-shot, brother Kenton?- 
but, as ne turns it over, its bare breast throws a flood of light on the living things turning into dead leaves, at a note of warning from the mother bird that he has killed. Instantly, he is in a panic, a revulsion of feeling sweeps over him that will break his heart unless he can do something to stay its fury. Away goes the gun, and the salt out of the pail, and he is down on his knees searching everywhere for the motherless chicks. They elude him, like the phantom shadows we pursue in unhappy dreams. His thought had been to capture them all, and put them in the salt pail and carry them home to be mothered by a hen; for he knew that old Spot, who wanted to mother the kitten when the hawks carried away her own chicks, would take them all. He went over the ground again and again, and when search had to be abandoned as hopeless, he had one chick that he had stepped on with his bare foot and crushed its life out. When he dropped the dead mother to pursue the young, she had fallen on her back with her pitiful naked breast still oozing blood, calling to the God of all mercies, the small boy thought, for vengeance. Putting the dead baby bird upon the pulseless bosom of its mother, he cast himself down beside both,-a forlorn little Cain, who could find no place of repentance though he sought it with tears. A couple of lines that Kipling wrote long afterward, came 
nearer than anything else ever written to voicing the speechless agony of his soul.

"Till I lay with naught to hide me,

'Neath the Scorn of All Things Made."

It must have been to save him from this sense of blood guiltiness that his father had forbidden all shooting in the breeding season. To do what he had done was a crime that the good deeds of a life-time would scarcely over balance or expiate. A sense of the meanness and shame of it grew as he buried the mother and the crushed chick in the same little grave, dug by his naked hands-hands that seemed anxious to cover up the stain of blood with the stain of earth. He never looked up the colts; making that the object of the expedition had been a lie, and this is what it had brought him, - a lasting stain on his very soul. It was not the gun's fault, he thought, as he shouldered it and started the longest way around to reach home, trudging dully along, feeling that its dead weight was a kind of an expiation. It was long after dark when he reached home, and hiding the gun in the granary, he crept supperless up to bed. He undressed by fierce flashes of lightning that kept nearly a continuous blaze in the room, and they proved the precursor of wind, rain, and hail that swept the earth and also the shuddering soul of the small boy that 


\section{0 \\ What Birds Have Done With Me}

was out in all the tempest struggling in vain, to shield from the merciless fury of the elements; the helpless things whose mother he had ruthlessly slain. Rain and years wash out many things, but the June day that went down in blackness, and the night of storm following, left an ineffaceable sense of shame and regret that would only pass with the mouldering back to dust of the brain upon which it was stamped.

When the very next day his two doves, leaving a pair of young birds at home, flew down to the village and were seen picking up grain around the mill, and were promptly shot by Dr. Coffee, the small boy felt that his crime was not to pass unnoticed. Had he been aware of the fact commented on by Shakespeare so many years ago, when he wrote of sucking doves, he need not have felt so bad when his squabs both died for want of the predigested food they get from their parents. About the only fun that the small boy had at this time was the joy of hating Dr. Coffee, and there is a good bit of evidence, of a circumstantial character, that would indicate that he never fully forgave him for killing his doves in the breeding season. To be sure, he had shot the Prairie Chicken, but he didn't know any better and there was no excuse of that kind to mitigate the crime of Dr. Coffee, and he would get his punishment either in this world or the next. For 
many years, he had a secret hope that every crowd started by an evangelist for the everlasting burning, was headed by this enormously fat Doctor, who would have burned grandly; and when the small boy not only a man himself, but one growing old, encountered old Dr. Coffee, deafer than an adder, and boarding at a hotel, because he was too ugly to live with his children, and actually feeing the night-clerk, every night, to pull him out of bed in case of a fire alarm that he would never hear, he not only was not sorry but he grinned from ear to ear, still remembering the doves. 


\section{CHAPTER IV}

THE KEEPER OF THE SPRING-HOUSE

Directly in front of a new summer hotel on a hill, and across a public road on the margin of the lake, was a cheap and impromptu spring house.

It had a gabled roof, was about six by eight in size, and was closed in with lattice work, with the exception of a place for a door on the road side. The simple affair was scarcely finished, when the roof was taken possession of by a Belted Kingfisher, who became known somewhat widely as "The Keeper of the Spring-house," the name probably growing out of the fact that he was rarely caught off duty, from early spring till late in the fall. In a figurative way, it might be said of him that he both opened and closed the season; arriving ahead of the south wind and the first shy violets, rollicking through the summer and painted October, and saying a reluctant farewell when the north wind chased a cloud of reluctant snow flakes into the black and sullen waters of the lake. 
He took possession without so much as, by your leave, taking the liberty of an old friend,for he and the man had known each other all their lives and what could be more natural, now that the man had a big house of his own, than his building a cheap summer affair for a longtime friend? Anyway the man never questioned his ownership, and how the Kingfisher hated the small boy who did. If he had any system of Theology, he must have classified all boys as the devil's imps from the bottomless pit. They invaded twice a day, before nine in the morning and shortly after four in the afternoon, his house, and actually attacked the keeper-assaulting him with volleys of stones. He shrieked his hatred and impotent rage at them and retreated, routed by an army of devils; but if they had all been of his size, he would have watched his chance and captured them, one by one, and tearing them limb from limb, fed them to his own nestlings.

$\mathrm{He}$ did not hate the man, and indeed he had no reason to, for neither he nor any of his family had ever received anything but kindness at his hands. To be sure, there was a time, when he had been a boy, and came very near acting like all boys; but in a way he had never been young,if thoughtlessness is the universal badge of youth -for even his boyish pranks had been seasoned with a consideration for the rights of living 


\section{What Birds Have Done With Me}

things, that is not always, alas, characteristic of mature age. Every Kingfisher on the Lake knows to this day, how he and his brother had worked for nearly a whole day to dig out a grand-father and grand-mother Kingfishers' nest in the high bank near "Gray Rock," and then and there repented of their evil deeds, and spent a half day longer to repair the injury they had done. There is an old and truly scientific saying, that all life comes from an egg, and perhaps it is a subconscious curiosity, that in some way never leaves us, about the origin of life, that makes a natural nest robber of every child. Though only eight and ten years old, they were wiser than the ancients, if there be truth to the story that they called the Kingfisher a Halcyon, and thought it made its nest on the water in stormless periods, from which the term "Halcyon days" has come down to us. How these urchins would have laughed at, and exulted over, those old worthies if they had known of the myth. To think that they could never find a single nest when the boys knew of three or four-what boobies they must have been-it is likely that we fail to give an idea of the scorn they would have felt and expressed picturesquely.

My, but the sun was red hot, and had his eye directly upon them, when they settled down at the lure of a possible white egg, whose existence 
so far was hearsay, to dig their way back in a gravelly soil, with a worn-out fire shovel, till the treasure should be revealed, a reward of both merit and labor, a veritable prize, for barring the eggs of the oriole; no others were so hard to get. Their education had not proceeded far enough so they could get the stimulus of knowing that they were digging like "badgers"- the animal on the coat of arms of their state-which was the fact; but it is doubtful if even that creature, whose burrowing ability is undoubted, would have assayed a tunnel in the kind of soil in which they were working. That beastly fire-shovel-they quickly christened it "Mr. Angleworm," for it would double up in their hands and twist in any direction, except straight ahead, when they attempted to force it any distance in the stubborn, sticky clay. They had scarcely half finished their task, when they noticed that the sun no longer looked squarely down upon them, but was watching them from over his right shoulder, to the west. They had had no dinner but they did not know it. They had forgotten the cries of the old birds, were unmindful of their blistered hands, - in fact, those hands only itched for one thing, the joy of grasping the white egg, that could be only a little way ahead. They had been carrying the dirt out in their hats, but they could do that no longer, for they had commenced to strike pellets that 
46 What Birds Have Done With Me

reeked of corruption, and made them sick at the stomach. Necessity is the Mother of invention, - when they could no longer use their hats, they tore the lining from the sleeve of an old jacket they found on the shore, knotted it at one end and had a sack for their dirt. The horrible, pestilential odor got worse and worse; it strangled, throttled them, and they could neither quit nor go on. A merciful providence took the matter out of their hands; they suddenly heard noises at the end of the tunnel, and using both hands as a telescope, beyond a field of carrion fish-bones, they could see the heads and open mouths of young birds. One glance into each other's eyes, and impelled by a common impulse, they fell over each other in their efforts to get out of their tunnel, they rolled over each other in their haste to get down the bank and bury their perspiring faces in the friendly water. It was delicious: stripping off shirt and trousers, they plunged in bodily, and like a good nurse in sickness, the lake bathed their bodies, - cooling the blood that for hours had been almost at fever heat and washing away the grime from face and hands-but the odor in their nostrils seemed beyond her, and did not pass for hours; not, in fact, till sleep, the great restorer, came with her poppy juice, that wipes away the world and all things therein.

It began to thunder before morning, and the 
first peal roused the "Deacon," and if he had not, in fact, dreamed about them, his first waking thought was a confused jumble of young Prairie Chickens and young Kingfishers at the mercy of the elements. If it rained and the water rushed down that bank, they would be drowned. They, the nest robbers, were responsible. Their duty was clear; it meant he and Hod to the rescue. He roused his brother, never mind whether it was by threats or promises, and it was getting light when they stole out of the house to pilfer two lengths of stove pipe from the granary, got a spade, and headed for the lake at a rate called by military tacticians, a forced march. The two lengths when joined together were a little too long, but when a fellow was doing the best he could, what more could be expected of him! They talked it over on their way back to the rescue. How could they know that they would find young birds?-and they wouldn't, either, if those fool parents hadn't been in such a hurry about getting to house-keeping. When they finally got the stove-pipe in place,- - just where the old tunnel had been, and the earth well packed around it,they couldn't stay to see if the birds would use it or not, for what had threatened to be a thunder shower, proved a deluge, and they had to seek refuge among the trees of the Seminary Land.

It was nearly a week, before they got back to 


\section{What Birds Have Done With Me}

examine their handiwork, and to their delight they saw the mother bird perched on the end of the length of stove-pipe, - at peace with all the world. This was before she spied the boys-or we could never have used that reference to peace. In view of all their labors, they felt rather surprised at the nature of the blessing she was calling down upon their heads; but what boy ever took anything to heart, in the way of personal abuse! Soon they were laughing at her, and as boys never feel real well acquainted with a thing till they have given it a new name, they forthwith christened her "Stove-pipe Jinny"; and when the Papa bird put in an appearance, they dubbed him "Gluey Bill." How boys get names for things is not easy to tell, but in the name of "Gluey Bill," the reference is obvious enough. The furniture at home had come from Pennsylvania, and at the last end of the journey had been drawn by ox team over seventy miles of corduroy road; hence the glue pot, that never was known to smell like a flower, was among the household gods, - and the Kingfisher's nest had every such odor on earth beaten to a frazzle. Surely the Divine Goodness must have withheld from the baby Kingfisher, olfactory glands-or that goodness may be questioned. From "Gluey Bill," the name, through some natural stage of contraction, became "Gooey Bill," and her name "Jinny Pipe,"-and 
so they will remain to man's last syllable of recorded time.

Shade of Ike Walton, as a fisherman in comparison to either "Jinny Pipe" or "Gooey Bill," you are as a pollywog to a whale. "Patience on a monument," come and hire yourself out as an understudy to the "Keeper of the Spring-house." All American Eagles, in the name of common honesty, I call upon you to dissolve your robbers' trust, and come and learn from "Gooey Bill" how to get a living on the square; "The Keeper of the Spring-house" would scorn seines, snag lines or phantom bait, - nothing under-handed about him. In the gray of the morning, when he comes sweeping down the shore from the bluffs along Sherwood Forest, he is sounding his rattle all the way, and when he hits the roof at his old fishingplace, he calls to all the little fishes, "Here I am, and it's to be a fair fight and no favor." When I read how the Psalmist said all fishermen are liars, then my Kingfisher is my refuge and a very present help in trouble; 'tis the "Keeper of the Spring-house" who has made it possible for me to find a sermon in a fisherman, and consequently good in everything.

Once upon a time the Man's Wife and little daughter, with a party of friends, were out in a little gasoline boat, and when they started away the skies were as sweet as Tennyson's "Dream of 
50 What Birds Have Done With Me

Fair Women," but when rounding "Norwegian Bay," on their way home, the engine stopped and a sudden gale struck them the same instant. There is no bottom to the lake along the rocks at "Lone Tree," toward which the frail craft was being carried. On the other side of "Sugar Loaf," which is a promontory, the Steamer "Queen of the Lake," was also making for home with her load of passengers, - -among whom was a Bird-Lover watching the shore with a pair of opera glasses. Suddenly coming directly from the shore toward the steamer, she saw a Kingfisher, and circling, within ten feet of it, he uttered an alarm cry and flew toward "Lone Tree." Watching the bird, she saw the signals of distress from the gasoline boat,-and the steamer put about and arrived just in time for a neat and spectacular rescue.

When the man heard the story of how the Kingfisher had seemingly called attention to the imminent wreck, he with the rest made light of it; but as a matter of fact, he added it to certain fancies long hidden in his heart, and as he tells them now, he wonders if any one will really understand. To him, all Kingfishers are related to "Jinny Pipe" and "Gooey Bill"; they are a part of his youth, and have their place among his early play-mates. The Kingfisher to the rescue, was just a coincidence, but a mighty pleasant thing 
to remember about an old friend, all the same. He doesn't pretend to know what such a bird may stand for in your life, and he couldn't make you understand all it stands for in his. But it's not the Robin or the Blue-bird that is the first to announce to him that Winter has finally capitulated, and is in full retreat; this news comes from the exultant rattle of the Kingfisher, causing the child's heart within the man, to start and tremble, and the welcome he extends is always quite voiceless, for it is only his heart that says, "Hello, 'Jinny Pipe'; Hello, 'Gooey Bill.'" And when the summer is over and gone, and October's last picture has faded and the tubes are twisted and dried, his heart in voiceless farewell always says, "Good-bye, 'Jinny Pipe'; Good-bye, 'Gooey Bill," " and the talk about the "Keeper of the Spring-house" at such a moment seems as a tale that is told. 


\title{
CHAPTER V
}

\author{
WINGS, WINGS, WINGS
}

Naturally enough we have been so intoxicated with the splendors of the civilization coming to the wilderness of Wisconsin, in a little over half a century, that we have had ears for no adverse criticism, and eyes for no visions of havoc, pitiless destruction, and wide desolation wrought by our conquering world God. We willingly admit that it seems to be the established order of the Universe that for something to live, something must die; however, such an admission does in no way take from us the natural and inalienable right to protest to such a law, fundamental though it be. Civilization not only takes toll of all weaker forms of life that stand in its way; it does more, it exterminates, it annihilates, and its word has gone out to all the wild life on the face of the earth: "Where I am, there ye cannot be."

Strangely enough, the small boy seemed to have some dim sense of this, for he had a feeling that the passers in the sky must have his attention first, - over the things that had a local and nearby 
home. Ah! those myriad things that came out of the southern sky in the spring and disappeared, always flying north, - would they ever come back? It seemed unlikely, and in his soul was the foreboding fear that the hour drew on apace when his eyes would search the desolation of vast fields of space and find no passing wing. It had been the great flocks, spring and fall-especially spring -that had taught him his A.B.C's of migration. The native, home birds that would be gone today and back to-morrow-with no appearance of ever having been away-scarcely suggested it; but the countless millions going by in the light of the sun, often darkening it like a cloud,coming from nowhere, and disappearing into nowhere-these were the obvious migrants, these the real world voyagers. The wings, the wings, the wings that gave a living thing the emancipation from the earth enjoyed by a cloud, the speed of the wind, and enabled them to traverse highways whose only street lamps were the stars,for he heard them going by in the night.

The living cloud from the sky that had struck him dumb that first spring, had been a vast flock of Passenger Pigeons. Clearly they had no fear of the little tad standing on a hill alone, and swept by, not a dozen feet above his head, with the sound of a rushing, mighty wind; and both the wind and the sound were real enough, for the 
54 What Birds Have Done With Me

one left him bare-headed, and the other half deafened him; and fear gripped his heart lest, in what seemed the onward rush of all things, the wings would carry him away. How beautiful they were, how graceful, - many had the flush of both the dawn and the evening sky on their breast, and the eyes with which they looked at you were fearless and full of confidence. No one knew it at that time but they constituted America's one characteristic "Moving Picture"-that all the countless billions of money since produced by our Civilization could not now replace. But more than this; let us suppose the physician of one of our multi-millionaires, J. Pierpont Morgan, said to be dying at Rome, had ordered for him a Passenger Pigeon, as the one thing that would save his life, the expenditure of his entire fortune, of fifty millions, would not have obtained it for him. This was the bird that the early settler netted, trapped, pounded from the roost by wagon loads and fed to hogs and used as fertilizer, and slaughtered and left where they fell to rot. Under the old Mosaic Law, a young, domestic Pigeon might be offered up as a sacrifice for sin, but the Civilization that we are expected to teach our children to regard as splendid, allowed all our wild pigeons to be sacrificed for naught; and the shame of their destruction should evermore be chronicled among our national sins. 


\section{Wings, Wings, Wings}

In numbers, next to the pigeons, came the ducks in flocks so vast that the individual members seemed as the stars of heaven. The pigeons belonged to a single variety, but the ducks to innumerable varieties-no two of whom seemed alike. When the hunting was good in the fall, as Adolph put it,- which simply meant the birds had come down from the north, - he often took the small boy with him to help retrieve the game; and that meant to help pick up a boat load. At such times he would devote some attention to the small boy's education, when they unloaded and sorted the duck, by telling him the names of the different kinds. The small boy long cherished in his memory some of the names, though at the time he half suspected that the resourceful little Frenchman depended for them more upon his imagination than upon his memory; "Ze Melard, ze blue and green-winged tel, ze butter bel, ze wisle wing, ze wood, ze canvas cover, ze pin tail, ze old squaw." The last two names were accepted with great mental reservation and were regarded as likely imaginary,-but turned out to be correct. Adolph thought he was doing a land office business if he got 60 cents a dozen for his ducks, often, half of which were Canvasback; and no one dreamed that the time would ever come when duck of that variety would sell in the New York market for \$10.00 each, - a price 


\section{What Birds Have Done With Me}

easily realized to-day. While vast numbers went on farther north, multitudes remained and nested in every lake, river, creek and little pond, and could be seen swimming around later in the season in the midst of their broods-almost like domesticated ducks, with whom they occasionally mixed freely.

Culver, Hamilton, and Spaulding ponds contained many such families, but in Culver's, the smallest of the three and the nearest to the village, all were shot early in the season; leaving open water there for three families of Woodduck that later on took possession with their pretty broods. It was the small boy's first summer in the wilderness and he became much interested in these families of wild things, and was on a fair way to a friendly acquaintance, when one Sunday while at Sunday-school, some Christian hunter visited the pond and killed four of the old birds and slightly wounded a fifth-a male that later on died; this left one mother bird and seven ducklings. The wild mother in spite of her good reasons to distrust man, soon overcame her fear of the little tad who came, literally, casting his bread upon the water. How the bright-eyed, incredibly swift-motioned little fellows would scramble for it; and they knew who brought it better than the small boy's sister, who had so 


\section{Wings, Wings, Wings}

much to say about his appetite for bread and butter meals.

A perfect gentleman, whose name was Darling and who had a business named after him in a nearby town, came over to sell Culver a patentright, - and got the wild mother and four of her babies who could not fly-and a mink mercifully prevented the remainder from starving to death. For a few days after this, had the teacher happened to glance at the small boy's slate, she would have seen the word Darling and might have concluded that she had surprised a first love affair; but she would have been miles from the truth, for that represented to him no term of endearment, but an active little flame of pretty-fierce hatred. The capital "D" was the one significant letter and it stood for a certain lean, hungry gentleman whose full costume comprised hoofs, horns and a tail.

The small boy knew something that few nature lovers of the day seem to know: namely, that in the bird kingdom, the duck is the natural and irresistible harlequin. Imagine a quiet sheet of water, on a peaceful October late afternoon, covered with countless thousands of ducks-before they had become the gun-shy creatures of to-day -and it requires no further imagination to see before you a Water Circus, the like of which you 


\section{What Birds Have Done With Me -}

never saw on earth: unless your memory carries you back to the early days in the wilderness when it still belonged to wild things. Our base-ball, foot-ball, and College field-day become tame affairs in comparison to the duck high carnival. Of course, he couldn't see it all quite clearly on account of the flying spray that they scattered to the four points of the compass, but the small boy never doubted that they were playing "I spy," "sheep in the pen," "anty over," and "pullaway"; and the wild screaming joy in the eternal joy of life was never exceeded since the stars sang together at the dawn of Creation. Where all this occurred, there is neither sight nor sound of living thing to-day. The waters are in uneasy motion, muttering incoherent complaints to the water flags that line the shore, and whispering in lonely places, the forgotten histories of all life's yesterdays.

Wings, wings, wings, there are yet wings in the upper air and the dimming eyes of age watch them from the same hill-top where the eyes of youth followed them in the long ago. Canadian geese in military precision hurl themselves across the sky, at an altitude where no fowler can do them harm, obedient to the mysterious call of the North. Few and scattered are the flocks compared to those that used to go by calling to each other in that hoarse, honking cry, that falls upon 
the ears of heaviness and sleep, in the mid-night, as an "all's well" from the watchers of the silent places. Adolph sometimes shot them when they stopped to rest or feed, but to the small boy it was an evil act, a kind of a treachery to a stranger from a far land who should have received hospitality. How big they were, and what a wonderful thing a wing was that could carry such a great bird through the sky, as fast as a train of cars could run on an iron track. The sky made them small, but the earth made them large, and until the Frenchman told him of his mistake, he had thought them the largest birds in the world. Adolph told him that to compare them to a Swan was like an old rooster to a big turkey.

Adolph also told him that swans were harder to see than geese, because they were white and flew higher and did not keep asking you to come and shoot at them-the way a fool goose did. The very next day he saw them, not flying in a great V-shaped flock as he had expected, but in a straight line, hard to tell from the white clouds that hovered about them and whose children they seemed to be. If they were not really the children of the clouds, maybe the clouds wanted to race with them; but as he watched them sail along they seemed too stately to race with anything, unless it might be with their own shadows - and they were clearly too high up to even see them. 
6o What Birds Have Done With Me

Of all the things with wings, they seemed the most wonderful and farthest removed from the common earth to which other creatures belonged, and he was greatly shocked when Adolph told him that "Ze woman, she use ze down to pretty ze dress." Not long after this, at church, he saw a very beautiful little girl wearing a blue merino cloak, with a hood to match, trimmed with Swan's down, and was not shocked, for some way she, also, seemed a child of the white clouds.

The cranes going by-'way up in the blue ether - with their weird cry, were things of the sky and not of the earth. They undoubtedly had wings but they did not seem to use them, but were blown along the great currents of air,-a part of them,- riding on their backs, with their long legs stuck out behind to steer with, as idle as the proverbial painted ship upon the painted ocean. In later years, the small boy had to very greatly revise his notion with regard to the crane as a super-terrestrial creature, and it became not only a creature of the earth, but of the low places of the earth, the swamps, and marshes and dismal fens, where slimy things crept and crawled and hid in rank grass. Like some other things, it became rather grotesque on close inspection, but one of Nature's pet jokes all the same. Every one, young and old, laughed at the ridiculous long legs, and yet concealed in those same stilts, from 
common observers, is a whole legal brief, going far to prove the adaptation of means to ends in the scheme of things. Those long legs, clearly intended for wading, would not be of much value if not a step could be taken without a splash; so that has been provided for, and the widespreading toes are carefully folded up by the same contraction of the muscles that raise the foot, and are not allowed to expand till the foot is again beneath the surface of the water, and consequently there is no splash. In spite of all this, perhaps the frog is about the only thing that does not regard the Crane as a joke.

"They shall mount up on wings, as Eagles," said the Prophet of God, foretelling the strength to be the inheritance of the Redeemed: and never was grander figure of speech used to portray super-human might. The power of flight reaches its final triumph in the king of the air; other winged things hurl themselves through it, while the Eagle alone, floats across fields of space claiming lazy kinship with the passing cloud. Effortless it climbs invisible spiral stairs that lead upward toward the very temple of the sun and drops back to earth, held in the secure embrace of some dreamy zephyr. It soars and seeks those far altitudes that no eye hath reached and through which dreams wander and lose their way. Along the rocky slopes of old Sugar Loaf, the 
62 What Birds Have Done With Me

small boy heard the young Eagles crying for food from a nest that overlooked lake and forest and plain, and he watched with never-flagging interest the old birds climbing the viewless ladders of the sky and he knew, as only those know who have never doubted, that when the dying Christian in the hymn, cried, "Lend me your wings, I mount, I fly,"-his soul was calling for the wings of an Eagle. 


\section{CHAPTER VI}

\section{PIRATES}

The immigrant of to-day, following the railroad, knows little or nothing of the privations suffered by those of fifty years ago, who preceded the railroad and in a way were swallowed up by the wilderness. Many of the early settlers of Wisconsin found themselves not only a hundred miles away from a market, but what was almost as bad, a hundred miles away from even a weekly newspaper, and in some cases destitute of anything to read. Even professional men carried their libraries in saddle-bags and any kind of reading was prized like a gift of the gods. The Nere York Tribune, the New York Weekly, the New York Ledger, came as angelic visitors. As a rule, no family took more than one of them and they were traded about till they were literally read to fragments, and the fragments kept to wad a gun. With regard to the two last-named it would, doubtless, have been better for the rising generation had they been used as gun wads before they were read at all, for what they offered 
64 What Birds Have Done With Me

starving minds were veritable "apples of Sodom." They were read by everybody, often read aloud so they could be quickly passed on to the next eager lot of readers; and their lurid pirate stories fixed themselves in the minds of the juvenile listeners to their very great harm. Perhaps some of them never forgot them, and at least one small boy had good reason to remember the worst of them-if there are degrees of iniquity in pirate stories-all the days of his life.

Captain Ludlow, of "The Sure Death," was a monster, - capable of such frightful atrocities that even the devil would have done himself credit to have disowned him as a subject. There was no Dr. Jekyll and Mr. Hyde about him, though at times having the mien of a perfect gentleman, he was always consistent, always the fiend incarnate. It could never be said of him that he did not care a hang for humanity-for his ambition seemed to be to hang the whole human family. He had a commendable pride in the originality of his treatment of captives; he had forced none of them to walk the plank - that was old-fashioned when he came upon deck-so all that fell into his hands had been given their exit from a world of trouble through the hangman's noose.

Of course always excepting himself and his first and second mates, Guzzling Jack and Gorging Jimmy, English Bone, a gaunt miscreant, was a 
person of great importance, for he was hangman, and that post was no sinecure on "The Sure Death." If one of the great family newspapers, alluded to above, is to be relied upon, Captain Ludlow, when business was heavy and many captives were coming his way, was in the habit of taking a day off and holding a general hanging bee. On such occasions, the Captain of "The Sure Death" would be present in a semi-official character, invariably white duck trousers, ruffled shirt, and scarlet jacket and cap-so covered with gold braid as to look like the field of the cloth of gold in miniature. It almost goes without the saying that on such occasions, he puffed his cigar, in all the bustle, with the bored expression of one forced by politeness to listen to a very old story. On such occasions, English Bone, the hangman, held the center of the stage-an artist in his line, -decorating the rigging with assorted bodies, heavy-weights below and so on up, with an infant at the fore-top gallant mast. It was always quite clear that in the mind of the author, English Bone had a mighty taking way with him. On more than one occasion when his Captain was bearing up manfully beneath all his gold lace on deck, "The Sure Death" hopelessly becalmed, English Bone had strung up one of the crew, just to add interest to a sunset at sea.

As the natural result of this kind of reading, 
the woods adjacent to the settlement were full of little pirates. On one summer afternoon, Shanty Pete's crew had come ashore from their waterlogged flat boat, and the crew to amuse their Captain, were staging one of English Bone's hanging bees. Captain Shanty Pete stood about minus the gold braid, but with the cigar and the bored look. Stub Miner, with his bandy legs, red hair, freckled nose and rabbit mouth that was ever agap, in no way looked the part of English Bone, the Sure Death's hangman, but was hungry for the job-and got it. Perhaps he proved his fitness for so much honor in the way he cursed his men for their clumsy efforts to erect a gallows, according to his rather vague orders. Captain Shanty Pete had finally to come to the rescue with his profanity as it was getting to be a question if his cigar, which had only been what is called a snipe at the beginning, would last through the execution. Guzzling Jack and Gorging Jimmy, i. e., the two little Eaton boys, finally saluted and pronounced all things ready.

Two sticks, with crotches at the top, had been driven into the ground and into the crotches was placed a horizontal bar and to this were attached the nooses-five in number-made of fish line and about two feet long. The trap was a slender wand of willow placed parallel to the bar above and about six inches below it, easily yanked out 
of shallow notches in the uprights. An old jacket at the foot of a big white oak nearby held the prisoners. Stub Miner, burlesquing English Bone, though he knew it not, now proceeded to place each captive in place and adjust the noose. Merciful heavens! They were five young Golden Woodpeckers nearly grown and as innocent and helpless as any other babies. They were clearly not at all afraid and clung to the fatal drop with wonderment in their bright eyes-and one of them actually opened its mouth to be fed. Now or never-if this slaughter of the innocent was not to take place-interference must come from some quarter and it so happened that a certain small boy, hidden behind a nearby cedar and fascinated by the horror of what had been going on before his eyes, was selected as the puny agent of that mysterious something that we call Providence.

When Shakespeare wrote of mercy as a universal quality that "droppeth as the gentle rain from heaven upon the place beneath," he should have made an exception of that flinty part of a pirate's anatomy, generally called a heart; for all pirates, especially little ones, know nothing of such softening influences. Intuitively, the small boy knew full well that any plea for mercy would not only be denied but would add zest to the gang's orgy of cruelty. Stub Miner, as Eng- 
lish Bone, was on the eve of springing the drop, when a kind of a human catapult shot out from behind the cedar and the head of it took him exactly in the pit of the stomach, and for a little time, in the beautiful and expressive language of Bret Hart-"the subject of proceedings interested him no more." Captain Shanty Pete was that spellbound that he "got his" before he could speak or move and went down beside the redoubtable English Bone-equally limp and equally drowsy. The little Eatons in retreat, the small boy was in possession of the field barely long enough to release the captives, who were too young to either walk or fly, when the "little Eatons" made a grand rally and he went down before their charge with both on top-and Shanty Pete, capping the climax, atop of the struggling trio. It's no use, at this late day, to recount all the pirates did to their helpless prisoner; sufficient to say that after he was securely bound with fish-line, Stub Miller walked over him and kicked him in the face-fortunately with bare feet.

The pirates now reorganized their hanging bee, first sending to the boat for a rope for the land-lubber who had dared to interfere with their sport; they would dispatch the bird-captives first, and then hang their would-be rescuer from the white-oak, close beside them, as a horrible exam- 
ple of the fate of all who attempted to interfere with their royal sport. Putting the small boy where he would have to witness the execution, they proceeded to once more arrange the young Woodpeckers on the drop, this time successfully pulled from beneath them. They swung by their necks, but it was found that their weight was not sufficient to even strangle them to death,-much less break their necks. Captain Shanty Pete was equal to the occasion; the "little Eatons" were ordered to get five stones, each bigger than the body of the captive to whose feet one was to be attached, then the hanging might proceed-after the fine model set by the great Captain Ludlow. If the small boy was really afraid of being hung, he could never afterward tell for certain, for like the "Tar Baby," he was saying nothing, but was alert and watchful as no "Tar Baby" ever was. Possibly it was on account of being so much closer to the earth than the rest that he was the first to hear the approaching footsteps of his deliverers.

Ben Burroughs and Ira Smith, two youths approaching what Lowell calls "the awful verge of manhood," strolling along the lake, by the merest accident, flanked the pirates and captured their captain and hangman, before those worthies knew their danger. Shanty Peter fairly roared for mercy and prayed for clear weather beneath 


\section{0 \\ What Birds Have Done With Me}

a rain of cuffs from the strong hands of Long Ben, as he was called. He did not have to be told a second time to cut the bands that made the small boy a prisoner and being on his knees, he thought without suggestion, of the apology, of which he made the small boy the recipient; pronouncing it with something of the unction of a divinity student, practicing the "have mercy upon us, most miserable sinners." English Bone, in the equally strong hands of his captor was also treading the thorny path of repentance and restitution. Mid a storm of "pitchforks and coals of fire," he released his captives-seemingly unhurt - and made five ascents of the white-oak, whence they had been taken, to restore each one to its home in the heart of the oak,- - secure from all enemies except young pirates. The "little Eatons" made good their escape so it was only to Pete and Stub that the final riot act was read, mild yanks and cuffs emphasizing important parts. They readily promised never to play pirates again, never to molest another bird's-nest, and to do their utmost to break up all other piratical gangs infesting the beautiful lake and the noble forest, already set aside as the site of an institution of learning. They were then asked separately and collectively, if they regarded themselves as soundly converted and answering in the affirmative, their captors led them out to the 
end of the pier-which was a tree fallen into the water-to which their boat was hitched, and knowing that they could swim like water-rats, they were solemnly assured that in the case of reformed pirates, baptism must follow without delay, and they were dropped into the lake. Wet and shivery and thoroughly humiliated, as they pulled their boat for home, it is to be hoped that Captain Ludlow, of "The Sure Death," and his noble compatriot, English Bone, seemed to them what they were in fact, the frightful monsters of a frightful dream.

That anything of lasting importance should have had its birth in this scrap among five little boys over a brood of young Woodpeckers, on the face of it is improbable, and yet the insignificant affair was not without its life-long influence upon the after-life of our small boy. He had been the rescuer of five young birds against great odds and these rescued birds, in a way, sent him forth, with an unflagging determination never to give up the struggle, against all possible odds, for the rescue of all birds from their human enemies, boys and men.

It was a forlorn little figure, with torn shirt and bloody nose, that went limping home amid the long shadows of the afternoon, not knowing that the pirates and the golden woodpeckers together had come very near making a hero out of him. 


\section{CHAPTER VII}

AN OLD LOG THAT WAS BEWITCHED

It is said of the bumblebee that he hums but never sings, and it may be said of the Ruffed Grouse, with equal truth, that he drums but never plays a tune; but his drumming, such as it is, in connection with the booming of the Prairie Chicken, constitutes an essential part of the great spring orchestra. In the forest of my early years, the wandering minstrel with a drum was everywhere and nowhere, silence quickly swallowing sound and vacancy places that seemed alive. Not only Wordsworth's Cuckoo is to be called "a wandering voice," but the name applies equally well to a vast number that we occasionally hear but seldom or never see. In the north woods on my father's farm, by a fence in a dense thicket was an old log, - a prostrate giant, whose bark had crumbled into nothingness and whose heart was a cavernous chamber of black emptiness.

Though it may seem a far cry to suggest a comparison between this venerable log and the 


\section{An Old Log that Was Bewitched}

statue of Memnon, that was said from time to time to give out a sound like the breaking of a harp-string, it is nevertheless a fact, much better authenticated than the story of the statue, that the log was full of uncanny, mysterious sounds that saluted the dawn and at certain seasons of the year, might be heard almost any time throughout the day. They did not sound like harp-strings, but were clearly alive with a thrilling affinity for a boy's heart-strings. Poe opened the door of his chamber and in there stepped a stately Raven of the saintly days of yore; but a thousand times I opened the door of the grove and peered in to find silence there, and nothing more. Silence, tense and inscrutable, fairly laying the somnolent old log upon which a woodland minstrel had stood, not two minutes before, making the welkin ring, and speedily eloped with the echoes. In those days, of a May morning, you might start to run it down and it broke out behind you; retrace your steps and you heard it to the right or left-clearly making a fool of you in a quest as impossible of success as an attempt to catch your own shadow.

It really seemed as though no one in the community could explain the mystery of the bewitched $\log$, but no one took it seriously and laughed at me as a rule, some resorting to Munchausen in- 


\section{4}

What Birds Have Done With Me

vention-common ways of meeting the eager inquiry of a child anxious to learn all about things in his new world.

My parents were city born and bred and knew nothing of nature. Clesen Smith, our neighbor on the East, told me-through a great cloud of tobacco smoke, typical of a hazy state of mindthat the sound was made by tree-toads, that doubtless made the old log their home. Grant Culver, to the East, was quite positive that the Fairies were using the log as a prison, for political offenders and what $I$ heard was an awful warning being given out from time to time by the miserable captive. Jerry Norton, the village liar, had three pussible explanations. A Woodchuck had a den under the log and what I heard was the Woodchuck chucking wood: a Prairie bull-snake had its den in the log and warned its children by pounding its tail on the ground when it was going away to spend the day: a Were-wolf lived in the $\log$ and the explosive sounds I heard were its gloating enumerations of the number of human creatures it had devoured.

Truth is said to be at the bottom of a well, but the explanation of mystery is often found waiting you at the side of the road, at the end of a long journey. Only after years of search did I find out the true explanation of the bewitched $\log$, and witchcraft was changed into love, an even 


\section{An Old Log that Was Bewitched}

greater mystery-fed by a million flames and fanned by ten million strange processes. Back in the primitive æons of life, love was fanned by battle, and the female was charmed to give herself to the victor; but the day dawned when love would be fanned by elements quite remote from physical force-fancy being captured by means too occult to be formulated, or expressed if formulated; fancy giving way to interest, and interest giving birth to a god, a goddess, a myth,the one great reality in a world of shadows.

We do not always find when we seek and we often stumble upon the thing for which we had long sought in vain. A half-domesticated, halfwild heifer, recently purchased by my father, escaped from the home pasture and was thought to be hiding a new-born calf somewhere in the north woods, and on a misty gray Saturday morning, I was the new member of a searching party, now quite worn out by two unsuccessful days of pursuit; trained intellect struggling with blind instinct. A fool cow and calf's brains making monkeys of lords of creation. No wonder everyone was out of humor and my proffered assistance was lightly esteemed. Long before daylight, with sundry pieces of venerable toast-forgotten by every one, and never-to-be-forgotten by me,-in my pocket, I took to the woods and probably would have taken to my heels had I run 


\section{What Birds Have Done With Me}

upon the black cow in a thicket and in the darkness mistaken her for a bear, of which I had heard much and seen little. It was fore-ordained from all eternity that my way that morning should take $m e$ in the neighborhood of the bewitched log and the approach of bare feet over wet leaves and grass must have been as near being shod with silence as it is ever possible to human kind, and in addition to this I was approaching from the northeast, an entirely new direction, and the very first glimpse of the log revealed the presence of something new-a big bird standing upon it in the attitude of a soldier on guard. We were both waiting for something, and unless something outside of us intervened, we would have to remain motionless, in statu quo, for twice ten thousand yearsand all the time silence like a mighty, invisible flood was rising higher and higher and threatening to drown us. Help! Rescue from the unspeakable thing into which we are sinking! We had not noticed it before, but all the time suggestion had been saying in a soothing voice, "sleep, sleep, go to sleep." What broke the spell was the sun in the east; the military bird broke into a wild gyration and emitted a torrent of sound, from now on no more mysterious than the breakfast bell at home. I showed my approval like Tam O'Shanter, but my witch fled, a brown streak, -I in pursuit to get an identifying look in the 


\section{An Old Log that Was Bewitched}

open-when not ten rods away I stumbled over a black calf that was quickly joined by its mother; and she and I wended our way home, each in possession of our dark secret.

There is this singular thing about a mystery; when you think it all cleared up, the sun of truth is just beginning to break through the clouds of error and the full noon is apt to be hours away. I had the calf in the barn and the cow in the pasture, and had been scolded at by my brothers and praised by my father before it dawned upon me that I did not begin to know all about the crazy Ruffed Grouse yet; whereas I knew who made the noise I did not have the ghost of an idea as to why he did it. It required weary hours of waiting and watching before proof, strong as Holy Writ, established his claim to being the most poetic of woodland minstrels beneath the window of the female of the species-the surrounding hills, her castle walls, and his loud lament, a woeful ballad to his mistress' eye-brow.

Let no man say, "Oh, vanity, thy name is woman," for man who has the first right to about everything has first claim to vanity as well. Mrs. Peacock, Mrs. Gobler and Mrs. Ruffed Grouse must have a certain amount of contempt for their silly husbands, always on dress parade, always trying to show off and attract attention. Especially is Mr. Ruffed Grouse's attempt to drum up ad- 


\section{What Birds Have Done With Me}

mirers little short of disgusting. With him, every year is leap year and the drumming is to give notice that he is at home and ready to receive proposals of marriage from eligible spinsters and attractive widows. Love is certainly blind, or no self-respecting female would fall in love with this Jumping-Jack, with a fog-horn attachment. Perhaps they finally marry him to stop his noise, but if such is the case the sacrifice is useless, for the noisy lover makes a noisy husband, just as a drunken lover makes a drunken husband. Much has been written and said against vanity, but seriously it is something of a question if it may not be a virtue masquerading as a vice. Making the most of what has been given you by Mother Nature isn't so bad, always trying to look your best cannot be condemned, and trying to make all the world love you suggests the golden rule in a party dress. If vanity is the detestable vice we have been taught to think it, then it follows as the night the day that Mr. Peacock, Mr. Gobbler and Mr. Ruffed Grouse will prove to be especially bad husbands, but as a matter of fact quite the reverse is the real state of the case. Mr. Gobbler, so prominent and respected on Thanksgiving occasions, is a perfect model of conjugal devotion, willingly taking upon himself fully one-half of all domestic duties and such a perfect under-study of his better half that if any calamity happens 
to her, domestic matters go along without a skip or a break. With regard to $\mathrm{Mr}$. Peacock, I could a tale unfold, but that is another story. There is a great deal to be heard about the private life of Mr. Ruffed Grouse, but one cannot and should not believe all they hear and nothing has been proven against him that would make it impossible to put on his tomb-stone the usual statement that he was a good neighbor, a devoted husband, and a kind father.

I am willing to bear testimony as to the good character of the vain fellow who had me and the old log bewitched. Though our acquaintance never could have been termed intimate, I entered into the family's joys and sorrows to some extent. I was not invited to the wedding, but happened along, so to speak, at the christening. A fine family, John Roger family, and when the little ones most needed a mother - a two or a fourlegged wolf got her-and the bereaved husband became the devoted father, bringing each and all up in the way they should go, and never once trying to drum up admirers,-I even found him shy of praise.

He loves wilderness ways and his home is the forest; his little journey in the world is to visit the clearing and we love to see him along highways that we may kill him on sight. Among wood-folk we always think of him as an alert 
business fellow and that leads to the fancy that he may be a commercial traveler undergoing a Ruffed Grouse re-incarnation.

I remember very distinctly how the forest had been adding tinsel to the fading colors of October that somber Sunday morning when I rushed out into the open, beyond the north edge of the North Woods, for some explanation of the barking of a dog and the sound of guns in a woods to the west, a half a mile away. To many, what was taking place would have been as difficult of interpretation as a forgotten dream, but to me it was all horribly distinct, to its last minutiæ. The Ruffed Grouse, this bird of mystery, whose drumming has bewitched many a boy, is himself bewitched by the barking of a dog under a tree, in which he has taken refuge; and a whole flock may be shot by gunners in full sight, if they shoot the birds on the lower branches first, without a single one attempting to escape by flight. Bitterly protesting, but so far away that I was as helpless as a man in a dream, I could do nothing but curse, for to me it was a foregone conclusion that these fine sportsmen were, as leisurely as they might pick apples, killing my Magician and his entire family. Dog and followers (at least one of them a mongrel), had disappeared before I reached the corner of the fence where the murder, most 
foul, had taken place. At first I thought nothing was to be seen but tramped and bloody grass and leaves, but a second examination revealed a bloody trail leading into a nearby tangle of berry bushes, - which pursued, led to a dead bird and also to the certainty that the gunners had left in a hurry, for the Commander-in-Chief of the Covey had been overlooked. He had been so full of life and now how dead he was, how inert-this week a watchful father, next week a bit of carrion, harmless and even beneficent in the scheme of Nature, and killed, really not for food, but for sport. Perhaps some old Brahmin rose up in me and my very soul was filled with loathing at the thought of taking life except as a stern necessity. I remember thinking so long as he had been killed for sport, no one should eat him, so I carried him back and hid his body in the hollow log where I had seen him first and rolled a heap of stones to the door of his fitting sepulcher.

I took my little grand-daughter last May to see the place and found only the stones remaining,more magic,- the old log had turned into a bank of violets. While the little child filled her chubby hands with Nature's blue dearlings, I said aloud: "Nothing walks with aimless feet, not one life shall be destroyed or cast as rubbish on the void, when God shall make the pile complete." She 
82 What Birds Have Done With Me

turned and faced me, and said: "What are you saying, Grand-daddy?" and in reply I could but say: "I don't think I can make you understand, Little One, for I don't think I could make anyone understand." 


\section{CHAPTER VIII}

\section{NOTHING SO SILLY AS A GOOSE}

It was all in the merry month of May, when the south wind is virile, and life everywhere follows its fleeting kisses, that the "Cathrine" left its pier with a merry little company on board to make the tour around one of Wisconsin's many beautiful lakes. The steamer was chartered and the sole object in view was pleasure, but he who goes after pleasure often finds, as did this company of merry-makers, that the whole expedition was from first to last, a "Wild Goose chase." In Pine Bay, on the south side, a Canadian Wild Goose was sighted, within the deep shadows of that rocky shore, and as they had practically ceased to be migrants at so late a date in the year, and as they never make their long journey to the far north in solitary state, it went without the saying that the lonely bird was there for the excellent reason that it could not fly and such, indeed, proved to be the case. Silly Goose that it was, it still had power to divide that jocund company; the vast majority thirsted for its blood and longed 


\section{What Birds Have Done With Me}

for a gun; a respectable minority admired its grace and alertness and one man among them all, and as it happened the host, determined to capture it, mend its broken wing, and in the fall migration, allow it, if it so willed, to go south among its fellows.

No trick, you doubtless fancy, for two stalwart young men in a boat with a good landing net, with a handle six feet long, to pick it up from the water. If you have been entertaining such a notion of the silliness of a Goose it would have been a surprising experience to have been one of the company on as astonishing a Wild Goose chase as has been pulled off in many a day. After an hour of valiant pursuit and most ignominious failure, a vote was taken whether to continue the trip or the chase; if the first proposition prevailed, each one would have to pocket the mortification of having been bested by a Goose. So we all stood pat and now belong to that respectable minority, who going on a "Wild Goose chase" return with rejoicing, bringing their bird with them. So far the pursuit had been so fast and furious that no one had been taxing his gray matter to any great extent, but the little voting intermission had put us in a judicial frame of mind and we shouted our collective wisdom like a well-drilled class in the A grade: "She doubles 
like a Hare; pursue with the steamer and that will give the men in the boat a chance."

Her undoing was in the discovery of her tactics. Like Pat and the Flea, when the men picked her up she was not there and reappeared rods away, floating to the surface, with neck stretched along the surface of the water, looking not unlike drifting sea-weed. Why had we not noticed that she always doubled back? We are only saved from dying of mortification by the fact that doughty Colonel H., direct from Washington, who took full command in the absence of our captain, in the rescue party, shouting wise saws and modern instances, also failed to notice that "she doubled like a Hare." The length of her swim under water was limited by the time she could get along without breathing, and when she came up beside the rowboat, she allowed herself to be gathered in without a struggle. I took her from Jim, our mighty hunter, and tied her legs with my pockethandkerchief and she lay at my feet upon the deck, still without a struggle, biding her time.

Half the pleasure of hunting is showing off the result of the chase to jealous enemies and admiring friends alike, and on my return to the hotel I put my Goose down upon the lawn that everyone might have a chance to admire us. Quick as a flash, the time she had been biding, arrived, 
and she was using fettered feet and her one sound wing in a burst of speed in the direction of the lake. That it took so many to capture her, disabled as she was, came like a secret little revelation along the line of kinship, which as no one mentioned it, rather increased our interest and affection for the creature that had such good cause to distrust man's tender mercies.

You'll not be interested in the modern surgery upon the compound, comminuted fracture beyond the fact that a perfect result was obtained and the Goose paid the M.D. his fee, day by day, as the case progressed. She received his ministrations without wincing, fighting, or apparent gratitude, and in every way proved a beautiful patient. After a more or less intimate acquaintance extending over several months, her physician felt as ignorant of much that pertained to her as Horace Smith confesses to have felt in the presence of the mummy. He knew her race, but neither her age nor station, and the question of sex proved utterly baffling. The baptismal name given was that of Canada, from a notion that the captive might owe allegiance to that far off Dominion. Once a week its attendant put the crockery crate, its prison-house, upon a wheelbarrow and took prison and captive to the lake for a swim. For the first few times when it found itself in its native element it made a des- 


\section{Nothing so Silly as a Goose}

perate effort to escape, diving to the bottom and beating the water into spray, then it gave it up as useless and never afterward repeated its struggle for liberty until that coveted possession came almost by itself. When it was clearly convalescent, and might have been sent home had it been a real patient in a hospital, the fracture having knit and all appliances removed, its medical attendant had a little yard built for it, half of which was in the lake and half on the shore, but no top was put over the four-foot wire fencing that made up the enclosure as it was a question if that was necessary in order to keep Canada in the United States. If Canada felt any gratitude for the treatment it was receiving its monarchial pride may have had something to do with the fact that it failed to mention it.

The silence, dignity and utter loneliness of its personality was not to be borne and its keeper, hearing of a celebrated domestic Goose raised by hand, like Pip, in "Great Expectations," and christened "Bildad" in his downy youth, lost no time in purchasing the same to act as guide, philosopher and friend of the mysterious Canada. Bildad was gorgonized with a stony British stare and the Dominion would have none of him. Then a Mrs. Goose was selected from Goose masses and put between the possible rivals, but Canada watched their betrothal with all the dignity that 
stamps the caste of Vere de Vere. They were three in a pen but not three of a kind, and though Canada did not seem conscious of their existence, there is some limit to what can be expected of good breeding and it may allowably escape what has become unendurable. Canada escaped from Bildad and his silly Goose of a wife. Knowing the difficulty of holding such opposite elements together, I was not greatly surprised and told the man to release the other two Geese, but to make no attempt to recapture Canada.

Now came a great surprise, we being thoroughly convinced that Minerva should have had a Wild Goose-wild, mind you-instead of an owl as emblematical of Wisdom, and having been taught to believe that the distance between Captivity and Freedom is a million times the length of the road between here and Tipperary, I found myself nonplused, dumbfounded when confronted by Canada strolling about the lawn quite to the manor born and just as though nothing had happened. She finally took up a position on the public road, three feet from the wagon track and not only rested her plump breast upon good old Mother Earth but put her confiding head under her wing and pretended to be asleep. Lobo, a curious Collie puppy, saw nothing feigned in her attitude and attempting a close acquaintance found her cruelly wide awake and endowed with 
the power of driving all thoughts of slumber from his universe. Lobo got his early, I mine later when it was borne in upon me that in the mind of at least one Goose there was only one man in the Universe and I was it. Every day she came to the hotel office door for the one man to feed her corn, other humans showered her with it but they might as well have thrown gravel stones. She did not run, she simply walked away, leaving every kernel. On moon-light nights, I often entertained a little audience by calling her in from a few rods out in the lake-she never went ten rods from home-and throwing corn into the water where she would dive for each individual kernel. Queer, isn't it, that whereas she could scarcely have tasted corn before her capture, she should have become so much more fond of it than Bildad and his Goose of a wife. It is sometimes arrogantly asserted that domesticated creatures have acquired at least a part of their wisdom from contact with man, while quite the reverse is true. Bildad was the heir of all the ages of domesticated Goosedom; Canada, direct from the wild, had forgotten a thousand times more than he ever knew. Comparing the two, Canada was a gentleman and a scholar; Bildad, a loafer and a grown-up gosling. One was an astronomer, a World Voyager; the other, a rich collection of untried-out Goose oil. How Canada 
had fought for her life, and on the other hand you can imagine Bildad going to sleep with his head resting across a chopping block. If that old story has any foundation in fact, it is my belief that it was a Wild Goose that saved Rome.

It is impossible to go into all her little ways through which she captivated my imagination, but take her for all in all, she was one of my most interesting patients from the wild. Here was the omnipresent speculation with regard to her: when fall came with countless numbers of her migrating kind, would her instinct be too strong for her local attachment? Vain speculation; the question never was settled. At dawn on the first day of "the open season," when our vanishing wild life may be slaughtered according to law, a drunken young hoodlum, from a neighboring town, shot Canada on the beach in front of the hotel. It was one of those little occurrences to be met with in life, when expression is apt to be of a character that would make its publication more or less of an indiscretion.

During all the days of her brief sojourn with us, Canada had never uttered a sound and for a long time this very fact associated her with all silent places. In the spring when we watched the flocks going north, when they finally melted into space and their last sound became inaudible, 


\section{Nothing so Silly as a Goose}

then occasionally the wrath of Canada would float along the passing shadow of something that was, and is not.

The Glenn County Club, in California, entertained two sportsmen?-God save the markfor a day's shooting. They went out where a wire fence held captive Canadian Geese, used as living decoys. On each side were "rifle-pits" for the killers-not hunters-and back of them another for the "guide," who could imitate the "honk" of a Wild Goose. In one hour, with their automatic shotguns, they had used up all their ammunition and, the account says, had to their credit-let us say discredit-two hundred and eighteen dead birds. They went back in the afternoon and killed enough more to bring the number of the slaughtered up to four hundred and fifty. This in America, in the name of Sport; we the people who are "the heirs of all the ages in the foremost ranks of Time" - still capable of a thing like that, and what is even more hideous, bragging over it and calling it glorious. No pair of crawling reptiles, or fierce, four-footed beasts, in the darkest jungle that ever existed in the remotest parts of this earth, have equaled this destruction of harmless creatures, from a mere lust to kill. Establish their right to be called "Pothunters" and you honor them, for comparatively, 
92 What Birds Have Done With Me

in an ethical point of view, the "Pot-hunter" is a Prince and a King, when lined up with the mere KILLER, who does it for fun.

Let us suppose that yonder, beneath some mighty dome, is hung a splendid canvas-Art holding Beauty captive - and they together, telling the story of heroic deeds. Across the face of even such a painting, I do not hesitate to hang a picture of Autumn-a word painting from a familiar poem-asking you to look at mine, instead of the triumph of Art that it but half conceals.

"A haze on the far horizon,

The infinite, tender sky,

The ripe, rich tint of the corn-fields,

And the wild Geese sailing high,-

And all over upland and lowland

The charm of the goldenrod,-

Some of us call it Autumn,

And others call it God."

This is as sweet and tender as the Dawn; here we find Hope and Fruition hand in hand-a golden fancy mixing the pigments and an infinite hand wielding the brush. Autumn is its own artist; October, as a painter, shaming the old masters by producing only perfection. The picture would be incomplete, imperfect were it not for the indispensable element of life supplied by the flock of birds sailing across the sky. Their mystic $\mathrm{V}$ is emblematical of splendid victory 
over terrestrial conditions, and its lesson to us, the Earth-born, is to hope on, hope ever. They are the weird musicians of the temple of the sky, across the day, beyond the night; we, strangers and pilgrims, hear their voices calling; as they fly, of the better-country far away.

$\mathrm{Oh}$ ! ye poor sportsmen of the automatic gun and the living decoy,- -know ye not that ye are robbing God's great picture of life,--His finished picture of the finished year?

On a wild March morning, before dawn, the writer of this little sketch seemed to be sinking into his last sleep, - the doctors had announced that they could do no more, members of the family despairing, and the nurses at their wit's end,when suddenly just over the house came the clamor of a passing flock of Wild Geese. The familiar sounds roused the one who was so near crossing the bar, and turning on his pillow, he cried faintly: "Bless you, oh! God bless you!" and at once started in to fight his way back to life again. 


\section{CHAPTER IX}

\section{A DISH OF ROBINS}

It has always been rather a matter of regret to me that we have to journey along to the middle of the alphabet to get the first letter in the name Robin. The bird thus designated should have been given a name commencing with the first letter of the alphabet for the excellent reason that, in the order of time, he comes first in our acquaintance with our bird neighbors. I have never known, in the North, a single individual who will not put him first in his identification of birds, and even in the South, in this respect, I rather think he scores over the ubiquitous Mocking Bird. He practically is the outer guard to the bird kingdom and later on a royal conductor into the inner shrine, for a person who does not know a Robin, does not know a thing of any bird, and the person who knows a Robin well, as a rule knows a whole lot about a lot of other birds. This will not seem strange when we call to mind the fact that Cock Robin is not only a splendid teacher of chart classes, but gets himself talked 


\section{A Dish of Robins}

about to nearly all the little people before they are out of their long dresses and they know about his need of stockings and shoes before they have any of their own, and romance is born when some inspired person, with his woeful history of Cock Robin and Jenny Wren at his command, leads uncertain little footsteps through the thrilling days of courtship, merciless disaster and death and sad obsequies through which the Dove can actually be heard mourning for some one else's love.

"John O' Mountains" found a dandelion and a Robin very much at home on a glacier in Alaska, and Cock Robin is a dandelion among birds, willing to make himself at home just about everywhere, if you will please keep him out of your pot-pies. From the savannahs and jungles of the tropics to beyond the tree-line in the far North, he adopts all countries and climes and what he whistles at sunset is what he whistled at dawn: "My country, 'tis of thee, sweet land of liberty, of thee I sing." Then again he is a very common unit of measure, to people generally, most birds being either larger or smaller than a Robin.

From her knowledge of his splendid appetite it almost looks as though Mother Goose might have entertained him at a church supper or had him spend a summer vacation with her. Let me see, what was it she said of his ability as a trencher 


\section{What Birds Have Done With Me}

man? "He could eat more victuals than three score men, a church and a steeple and all the good people and yet his belly wasn't half full."

Once when I was calling professionally on a sick lad, his mother stopped in a half-apologetic manner to consult me about a sick bird they had in the house-a wild bird picked up on the lawn two days before. After the manner of doctors, I declined to give a diagnosis till I had an opportunity to examine my prospective patient; but when I saw her coming with a Robin in her hand, I knew at once that what ailed this patient was just the opposite to what ailed her gorged little boy, the bird was starving. Evidently, the good lady's education had not included Mother Goose or she would not have entertained the notion that on a diet of two horse-flies and one angle-worm, in two days, the case was likely one of indigestion. Again after the manner of my calling, I said: "This is a fatal case, you should have called me earlier, very sad, very sad, for in a land of plenty, it is simple starvation. A hundred horse-flies one day and a hundred angle-worms the next, might have carried him along until he was old enough to go to church alone and look after himself." As a matter of fact, a growing young Robin requires more than its own weight of food daily. You who live across the street or in the next house to a girl who practices on the piano five hours 


\section{A Dish of Robins}

a day, may thank your lucky stars that kind Mother Nature did not crucify you with a sense of hearing exaggerated into an acuteness that enables him to locate the movement of a worm under ground two yards away. It seems unconditional surrender upon the part of the worm when $\mathrm{Mr}$. Robin comes calling, but he gives up the ghost to the fisherman only after a struggle, and what is worse, often in a niggardly half-a-loaf fashion.

W. H. Hudson, the famous English naturalist, has a book whose title is "Birds and Man," as though they were inseparable, but as a matter of fact there is only one bird inseparably associated with man, and that is the Robin. He can't get too close, and if given the slightest chance does courting, builds his nest, and rears his family by preference under the veranda where human creatures pass at all hours of the day, and cats prowl at all hours of the night. In Mr. Hudson's book, to which I have just referred, he tells the story of an Owl, reared in captivity and without fear of man. So confiding was it, that coming, like all Owls on noiseless wing, it would light on the shoulder of any human creature who might happen along in the night. Some one, supposing himself attacked, struck it to the ground and broke its wing with a club. It survived its injury, but its confidence in man was at an end and it grew wilder and wilder until it finally returned to 
its native forest, as wild or wilder than any of its kind.

The Apostle Paul's narration of having been scourged, beaten with rods, and made to fight with beasts at Ephesus, tragic history though it be, still does not give him a place among martyrs to be compared to the high perch that the demure and cheerful Robin-Redbreast, that you see on your lawn, of a summer morning, has earned for himself. In very fact, he dies daily as the result of ignorant persecution,-Hunnish, ruthless slaughter.

With the single exception of the remediless slaughter of the Passenger Pigeon, no other family of birds has suffered what the Robin has and still survives. $\mathrm{He}$ is, always excepting the Chickadee, the optimist of the bird kingdom, jolly under the buffeting of March winds and rollicking through adverse conditions that would justify the grouch of grouches. For unknown ages half the Robin's life has been spent in that part of this country, known since its settlement as the Southern States and, since the coming of the white man, the birds' Inferno-a St. Bartholomew of birds generally speaking, but a veritable slaughter-house for this winter resident in particular.

It is with shame and humiliation that I append the following indictment against my brother man, and the president of the Grand Jury is no less a 


\section{A Dish of Robins}

person than T. Gilbert Pearson, Secretary of the National Association of Audubon Societies:

"Robins in winter sometimes congregate by thousands to roost at a favorite spot, and here the hunters often come to take them, in the manner, Audubon tells us, people took the Wild Pigeons during the last century. Stories of their killing creep into the public press, and over their coffee men marvel at the slaughter of birds that goes on, sometimes in their immediate neighborhood. Here is an authentic account of the raiding of one such roost, given the writer by $D r$. P. P. Claxton, of the University of Tennessee. He was familiar with many of the details, and will vouch for the truthfulness of the facts here set forth. He says: 'The roost to which I refer was situated in what is locally known as a "cedar glade," near Fosterville, Bedford County, Tennessee. This is a great cedar country, and Robins used to come in immense numbers during the winter months, to feed on the berries. By the middle of a winter's afternoon, the birds would begin coming by our house in enormous flocks which would follow one another like great waves moving on in the direction of the roost. They would continue to pass until night. We lived fifteen miles from the roost, and it was a matter of common observation that the birds came in this manner from all quarters. 
Ioo What Birds Have Done With Me

"The spot which the roost occupied was not unlike numerous others that might have been selected. The trees grew to a height of from five to thirty feet, and for a mile square were literally loaded at night with Robins. Hunting them while they roosted was a favorite sport. A man would climb a cedar tree with a torch, while his companions with poles and clubs would disturb the sleeping hundreds on the adjacent trees. Blinded by the light, the suddenly awakened birds flew to the torch bearer, who, as he seized each bird, would quickly pull off its head, and drop it into a sack suspended from his shoulder.

" 'The capture of three or four hundred birds was an ordinary night's work. Men and boys would come in wagons from all the adjoining counties and camp near the roost for the purpose of killing Robins. Many times, one hundred or more hunters with torches and clubs would be at work in a single night. For three years this tremendous slaughter continued in winter, and then the survivors deserted the roost." "

These are almost the identical methods employed in killing untold numbers of Wild Pigeons, which is today probably an extinct bird in America. This is followed by the testimony of William Dutcher, the very Commander-in-Chief of all constructive methods and conservative bird work in America. 
"Wherever the Robin breeds within the confines of civilization, man is its friend, and a mutual attachment has grown up that borders on sentiment. The man extends his protection and the bird rewards by making his home almost under the same roof tree, displaying a confidence in his human brother that is begotten by lack of fear.

"In the Robin's winter home in the southland, all is different, for there no sentiment but that of gastronomics is displayed; the bird is simply a tender morsel to be made an integral part of a stew or a pie. In Central Tennessee are large tracts of cedars, the berries of which serve to attract myriads of Robins in the winter. One small hamlet in this district sends to market annually enough Robins to return $\$ 500$, at five cents per dozen, equal to I20,000 birds. My informant naively says : 'They are easily caught at night in the roost in young cedars; we go to the roost with a torch and kill them with sticks, others climb the trees and catch the Robins as they fly in.' One of the officers of the Louisiana Audubon Society furnishes the following information regarding Robin slaughter in his own state: 'They are commonly killed for home consumption and for marketing, a conservative estimate of the number killed annually being from a quarter of a million in ordinary years to a million when they are un- 
102 What Birds Have Done With Me

usually plenty. During the past winter one gunner killed over 300 Robins in one day, and in one village in the state the boys and young men are vying with each other for a record in Robinkilling, the present high score being 200 birds in one day.' Better, by far, sentiment than slaughter, as the one preserves and the other destroys what is of great value, as will be proven later."

From these gloomy pictures of greed, and blood-lust and depravity, I turn to the annual visits of a pair of Robins-possibly escapes from the bird shambles in Tennessee-who for five years nested in a vegetable dish on a two-by-four, in an open passageway, just outside my office door. The first little dish was left there by accident and found and appropriated by the birds, and afterward was put there for their convenience. What beautiful confidence and seeming affection for man in spite of his vile treatment of them in certain localities; building their home, without hands, open to human inspection by the door where he passed many times a day. Later on, the bright-eyed babies adopted each visitor as a foster parent and never failed to stretch wide their big, wide mouths for supplementary feedings. Ours was the only dish of Robins to be spoken of without loathing and disgust. It was surely the same pair that came year after year to an accustomed nesting place, for after the fifth year no nest has 
ever been built there, though an empty dish, covered by dust, like the little toy soldier, is still "waiting the long years through." Till death overtook them, they came unto their own, and their own received them with hearts full of affection.

I never see a Robin, cheerful and active as he always is, without a feeling that I am confronting an object that stands for much that is best in life. To me, he is eternal hope, dressed in working clothes. The poet Campbell dressed up hope so gorgeously that he makes you feel like Moses in the presence of the burning bush:

Eternal HOPE! when yonder spheres sublime Peal'd their first notes to sound the march of Time,

Thy joyous youth began - but not to fadeWhen all the sister planets have decay'd;

When, wrapt in fire, the realms of ether glow, And Heaven's last thunder shakes the world below,

Thou, undismay'd shalt o'er the ruins smile And light thy torch at Nature's funeral pile.

Against these lurid surroundings of eternal hope in the last rays of a burning sunset, I have a memory picture of a living incarnate eternal hope in the cool dawn, after a night of tempest,- - and this living hope is only a Robin redbreast. A tornado, in the blackness of darkness, wrecked a 


\section{What Birds Have Done With Me}

house in which was a woman and her little daughter, the husband and father, a fresh air tubercular case, in a shack outside; all three found themselves together, they knew not how, stunned, bruised, despairing. Though not mortally injured, they and all their friends united in the feeling that unmerciful disaster had done its worst. It was a case of who has woes like unto my woes and individually and collectively, they looked the part.

There came into my mind some words that I had learned from a song of doubt that seemed a pretty good expression of my own pessimism:
"There is no good! There is no God And faith and hope is a heartless cheat Baring the back for the devil's rod And scattering thorns for the feet."

Then I saw the Robin! His nest had been hurled from a tree and the eggs all crushed, but he wasn't crushed,-far from it. The very embodiment of eternal hope, cheerfulness and energy, he and his busy wife were getting ready to build a new nest in a wood-shed that had outstood the storm.

Your pardon, but I hear a Robin and am going out in the sweet sunshine to get the uplift of a moment's association before the night cometh, with man's closest bird friend. 


\section{CHAPTER X}

MR. CHICKADEE

It has been said that America comprises Rhode Island and the other States of the Union. I understand it to mean that little Rhody is not to be bunched, but demands especial mention. Now be this as it may, something of the kind certainly applies to the Chickadee,- to any one who really knows him, it is the Chickadee always having especial mention, and the rest of the feathered creatures that make up the bird kingdom. It was said many years ago, that to know Madam Récamier was equivalent to a polite education, and it may be said with even greater truth that to know one Chickadee is equivalent to a scientific knowledge of all the stuffed birds in kingdom come.

As the only interest the majority of people have in a bird is its value for food, I want to say right here and now, that for that purpose, as a neighbor woman, here in the South, said of her husband: "He haint worth shooten." Down in Dixie Land, where nearly every bird that flies 


\section{I06 What Birds Have Done With Me}

finds its way to the table, I never succeeded in running down any sufficient proof to convince me that any human hyena had ever devoured Chickadees, though such may be the fact. Without the excuse of starvation, staring him in the face, the libel on God's creatures, who would do a thing like that ought to be Anathema Maranatha.

As Mr. Chickadee never had an enemy, and isn't of value for food, it would look as though in their relation he never had any valid reason to distrust man; but that is far from the truth, for he, in common with all other birds, has had good reason to fear "the relentless, remorseless bird-skin collector." To kill a Chickadee for any purpose seems almost next to the murder of an infant for the coral on its neck, in fact the Chickadee is the real Peter Pan of the bird kingdom. $\mathrm{He}$ has never grown up, but from first to last is a dear goo-gooing baby; guileless, confiding, carefree, with close relations to all our happy yesterdays and vitally connected with all our longed-for to-morrows; the Alpha and Omega of bird life.

Adolph Buzze had about the right notion with regard to the blessed Chickadee. When he was building his cabin in the woods, in zero weather, they came in great numbers, and I was astonished beyond measure to find wild birds so intimate with a human creature. He picked out yellow worms from between the bark and the log he was hew- 
ing for the log house, and scattered them at his feet and they came in flocks, Adolph calling them "Frenchman's wood chicks." Maybe Adolph was a poet for this sounds something like it. I asked him where they came from. He did not answer at first but after awhile, with a far-away look on his face, he pointed to the sky and said: "When Frenchman build little house in woods, Mighty God send blessings by Chicks. See, easy 'nuff."

In early life, in common with so many foolish people, I took it for granted that something of value may be learned about birds in the study of stuffed specimens. In nearly the first case was a stuffed Chickadee, possibly one of the very messengers that had brought a blessing from "Mighty God" to the Frenchman's cabin so many years ago. It was rather an unfortunate experience for me, from that moment to the present time I feel about the whole wretched business as I imagine a devotee of religion would feel if he entered a cathedral, of his own faith, and found Cherubs pinned to the walls like butterflies in cases.

Cæsar dead and Cæsar alive are a million miles apart. The Chickadee in his natural environment, very much alive, with his little song so full and running over with cheer, and the pitiful stuffed specimen, named and numbered and sur- 


\section{I08 What Birds Have Done With Me}

rounded with crude decorative attempts is a travesty of the real thing, who as Robert Browning said of the thrush:

\section{"He sings each song twice over, \\ Lest you should think he never could recapture The first fine careless rapture."}

The movie man calls his undeveloped films "stills," but these dead and dusty things in cases, that once were birds, can never be developed into something with a vital relation to life, they are "stills" forever. To study them is to study death, not life; as well study the withered flower, the dead and leafless tree, or a moss-grown tomb.

I am yet to meet any bird-lover who was ready to admit that he ever learned anything of birds of real value by the study of the stuffed specimens in the museum and, of course, pictures of these stuffed specimens are equally worthless. I once asked a class in high school to name for me a photograph of "Bob White" after he had disappeared from Wisconsin, that had been made from a stuffed specimen-and someone called it a Turkey Buzzard, without a dissenting voice being raised in the class. Indeed, that fine naturalist, W. H. Hudson, in his book, "Birds and Man," repudiates the notion that anything can be learned of birds by the study of the finest collection in existence. He says: "These collections help no 


\section{Mr. Chickadee}

one, and their effect is confusing and in many ways injurious to the mind, especially to the young. A multitude of specimens are brought before the sight, each and every one a falsification and degradation of nature, and the impression left is of an assemblage, or mob, of incongruous forms, and of a confusion of colors."

"These dreary remnants of dead things set before them as restorations and as semblances of life, produce a profoundly depressing effect." "The best work of the taxidermist, who has given a lifetime to his bastard art, produces in the mind only sensations of irritation and disgust." From the above extracts from his writings, it is easy to get his point of view with regard to the stuffed specimen as unnecessary and useless in the study of the birds he knew from a close and extended personal relation in their natural environment. It is scarcely putting it too strongly to say that according to his system of theology the collector stood for the devil himself.

The difference between a "Bird Lover" and an "Ornithologist" is much the same as between a "Demonstrator of Anatomy" and a "Family Physician," one gains his facts from death, the dissection of a dead body, the other from life, the study of a living creature. Follow in the footsteps of the Ornithologist, pure and simple, and they will lead you to a shamble, a Valley of 


\section{Io What Birds Have Done With Me}

Shadows, where death reigns, making one think of what King Herod did to this world when he ordered the slaughter of the innocent. Systematic Ornithology is scarcely necessary at present, it has been done and well done, and back of much of the so-called scientific examination of birds' stomachs is the commercial demand for a stuffed specimen. On the first page of our this week's village paper is an article on birds, a scientific article, beyond question; an account of the examination of the stomachs of some of our rare and beautiful birds is given and the statement is made that 27 I stomachs were available.

This certainly suggests a successful drive upon the part of the Allies-Scientists, Plume Hunters and Curators. We can but adopt the justly celebrated words of Madame Roland and cry out: "O! Blind and deaf and bloody Ornithology,"what crimes have been committed in thy name.'"

You can learn something about birds in a museum that happens to have a collection of stuffed specimens, and most museums have, and you can learn something of the piano, under a good teacher, if you never have anything but a dumb instrument to practice upon, but in both cases the element of life is wanting and discord will be the inevitable result of misdirected study.

In all his long years of study in the Philippines, I notice that Dean Worcester failed to secure the 
skin or stuffed specimen of a single native and no one scoffed at his failure to do so; but had he been an Ornithologist studying birds, such actions would have discredited his work for all time. Now as a matter of fact we "Bird Lovers" care mighty little about the inside of a bird, and what we want to learn most of all is how to protect them from their enemies and their so-called friends, who simply regard them as being worth skinning.

Scorning to make the slightest concession to the man "whose god is his belly," in passing, perhaps it will be as well to make a little concession to the man whose god is a little row of figures showing the net earnings, for three hundred and sixtyfive days, of the farm in which every other interest is merged, and assure him that his Chickadees brought him in more than his chickens. I do not care whether you believe it or not, but all growing things are menaced by a mighty and ever-increasing army of insects, and this tiny Chickadee is a dough-boy attacking the enemy in his trenches and destroying as many as five or ten thousand on a single drive. This country has National Forests and the Chickadee is our best National Forester. Nevertheless I am loath to discuss his economic value, for to me it seems a bit like asking the economic value of the benediction that follows after the prayer. We cannot put an esti- 


\section{What Birds Have Done With Me}

mate on spirituality and the Chickadee is a spirit and must be worshiped in spirit and in truth.

If men realized their condition of pur-blindness, they would have to say, with the one of old whose sight was being restored, "I see men as trees walking," for it's only the exceptional person who really sees things just as they are; for only a few things carry any impression to the brain, and where that actually takes place, it is soon effaced. A certain man went from New York to Boston and when his friends asked him what he saw, he replied in a perplexed manner: "Oh! nothing much; all I remember is two haystacks I saw out the car window, but they were going in an opposite direction." A brilliant man who graduated from Harvard at nineteen went for a familiar walk along a much-travelled road one Sunday morning, taking with him his two boys, aged six and eight, and a seven-year-old daughter of his host. On his return he said to the little girl's father: "Your daughter made me feel like a fool this morning. As you know, I have taken this walk two or three times a day for the last two weeks and during all that time I can recall seeing only two birds, a Robin and some kind of a wader, so when your little daughter pointed out a half a dozen and knew all about them, too, it made me feel like no end of a fool." An unusually fine, big-hearted, intelligent man, 
but alas, the "trees he saw walking" had no leaves on them.

A few years ago, with the help of this same little girl, now grown to womanhood, we devoted some winter days, - we each had our separate window, - to watching the Chickadees that came to the free lunch counter that we maintained outside on the veranda. By no stretch of the imagination could we have called our work either Salvation Army or Red Cross, for our visiting doughboys always brought their cheer with them. They all wore the same uniform but no two looked alike, and by the third day all had gone through with their baptismal service and in the name of the Father, the Son and the Holy Ghost, had been given Christian names. Please do not think that I am going to give the whole list of names, for such is not my intention, except in the case of certain individuals to whom you are given a special introduction. It went a long way in the direction of confidential relations when we could call each by his first name and with them as with people, nicknames stood for chumminess. "Othello" was certainly blacker than the average, but to be perfectly honest, failed a little in jealousy toward his wife, "White Girl," and tragedy was unknown in a conventional marriage in which they lived happily ever afterward. Neither could we keep it up, and later on they became "Blackie" 
II4 What Birds Have Done With Me

and "Whitey," the rather common members of a rather uncommon community. Of course she knew that her husband had done his country some service and that was all there was about it. "Romeo" and "Juliet" were very much in evidence, and while they had cut out the balcony scene altogether, they gave us many a veranda scene, which is the next thing, and even at this late day I feel it perfectly right to tell the truth (and I have a witness who will also swear to it) throughout the entire veranda scene, they were always eating peanuts. He was some lover but with a trifle too much assurance, and while we never did, we were always fearful of hearing the word universal used in connection with his ability to do a single balcony scene. Anyway, it's the good husband that counts in the journey of the years rather than the great lover. In a quiet and harmless way there were reasons for suspecting "Juliet" of being a bit flirtatious, which may have given "Romeo" cause for being too ready to crowd his attentions upon strangers on short notice. However this may be, before the first season was over, matrons were calling him Mr. Impudence and the name stuck, without any baptismal service.

It is a fact, though I question if well known, that a raw peanut shelled and sliced across, is to a winter bird what candy is to a child. In a 
shallow cigar box, tacked on the window sill, was kept a supply of fine-cut suet, hemp seed, and sliced peanut; a well-balanced ration, but not balanced for long as the peanut would disappear like snow in summer, leaving only the hemp seed and the suet.- All accepted the inevitable with a fair amount of Christian patience and resignation, with the exception of Mr. Impudence, who never failed to be outraged and ready to voice his wrongs to the world at large, and to the head waiter, grinning at him out of the window, in particular. I am not going to admit that he actually swore at me, but the way he would droop his wings and hurl expletives at me that were neither necessary nor ornamental, made me feel just as if I had been sworn at. When I supplied his needs, he blessed me with the unction of a bishop offering forgiveness to a penitent sinner. Indeed, he knew who it was that put the food in the box and when having made an exhibition of himself, if I had not compared him to a bishop, I would tell you that he would actually do penance himself by taking a hemp seed and flying to a nearby tree, hold the seed against a limb with his middle toe, pick out the heart, and devour the kernel as though it had become to him a means of grace. My daughter had a Chick that she called "Mother Mary," of so devout a look and gracious a mien that she insisted that the old masters had 


\section{I16 What Birds Have Done With Me}

painted the expression a thousand times. Well! perhaps. Cheerful and fearless, what can be more exalted? What a joyous company, a little lower than the angels, but super-human just the same! All agree that there is a great gulf between man and the "animal kingdom," but the Chickadee bridges it in a single, uninterrupted journey, when he comes flying from nowhere to light upon your hand. Victor Hugo once said: "No man who has ever really laughed can ever afterward be bad." Be this as it may, I am thoroughly convinced that after a wild bird has crossed the gulf and voluntarily submitted itself to your loving kindness, it thereby swings open the door to its own kingdom and makes of you a loyal ally, for from that time on you are a man who has dreamed dreams and seen visions.

In mid-afternoon of a gray winter day, returning from a cold and difficult drive over, or through, mighty drifts, my wife met me at the door and asked if I would not feed the birds at once for a party from a nearby town who had brought two little girls to see the birds eat out of my hand and had been waiting for some time in spite of drifting roads. I immediately attempted to comply and for a bad ten minutes certainly felt like a large-sized "Nature Faker," for the little flock of Chickadees that came at my call would not come near the tempting sliced pea- 
nut that I held in my open hand. They came into the railing of the veranda just over my head, and Mr. Impudence bombed me with expletives and they all "dee de de deed" me at a great rate, but eat out of my hand they would not. I finally "got it through my hair" that they had a not unnatural instinct against a fur-bearing animal, and I had kept on my Coonskin coat. I dropped it off, and presto, I was no Nature Faker at all, but a lunch counter where no meal ticket was required.

The next winter my daughter, after an illness, spent some hours a day in a wheel-chair on this same veranda and the Chickadees overcame their fear of her fur coat and simply walked all over her; often taking peanuts from her hand and flying up to her hat, which they used as a table. I would have you know that the Chickadee has very pretty table manners, - in violent contrast, for instance, to the Nut-hatch, whose table manners are atrocious.

We long since ceased to cultivate too great an intimacy with our bird friends, being convinced that it is a doubtful kindness to rob them of their instinct of self-preservation, and above all else teach them not to be shy of man. Over on another street, fully a mile away, a Chick attempted to investigate the bowl of a pipe that an old German had in his mouth but was not smoking,possibly looking for a place to hole up in the cold 


\section{I18 What Birds Have Done With Me}

weather,- and the man thinking himself attacked, struck the friendly little creature to the ground and killed him. It was certainly a warning to us, for we had failed to teach our birds not to attempt even the average pipe without a gas-mask.

In this little study of the Chickadee it has been hard to stick to prose, which is my only reason for lapsing into rhyme.

When the blizzard from the Northland

Holds the world in fierce embrace

And ten million swirling crystals

Sting you, blind you, smite your face;

And your world is not your world, Grotesque distortions, bush and tree;

Above the raging, howling tempest

Comes a joyous chick-a-dee.

In the soul there's something hidden,

That such a message comes to greet;

Above the rage of human passion

Comes a whisper strangely sweet;

A little song from out the tempest,

Born of hope for you and me,

There's love eternal in the storm cloud

When this bird sings chick-a-dee. 


\section{CHAPTER XI}

THE SONG AND THE SINGER

Gene Stratton-Porter's "Song of the Cardinal" is a kind of a winged epic and at the same time a passionate protest against the man with a gun. The man with a gun is consciously attempting to kill a singer, but is quite unconscious of the fact that if he succeeds he will also have eliminated a song from the waning chorus of the summer time.

This sad old world is in crying need of more songs, but each year the number of singers grows less and the volume of song fainter and fainter and in places it has been swallowed up by all pervading silence. Song is something vast and great, at large in nature, waiting for the voice that can give it utterance and none can say that it was not born close to that realm where angels have their birth. Whether the utterance comes to us through the medium of a bird or a human singer, the uplift is identical and always in the direction of the better things in life.

On Howard Avenue, Biloxi, Miss., a few years ago there was a fruit-stand, managed by an old 


\section{I20 What Birds Have Done With Me}

Italian woman and she had in captivity a wonderfully beautiful Cardinal, the one bird that carries the colors of the University of Wisconsin through all the Southland, and this splendid fellow had not only been robbed of his birth-right of freedom, but his eyes had been put out with a red-hot iron that he might not be able to tell night from day and would thus forever keep on calling for a dawn whose approach he would never again behold. Fight down your indignation and honest rage against the perpetrator of the hideous outrage, as I did mine, and get down on your knees and thank Heaven that neither captivity nor blindness, nor both together, can silence a singer that is a member of God's orchestra.

When life is in its fresh, glowing, splendid morning, youth with its ardors and unvoiced longings demands the new songs, but when experience has steadied, possibly saddened, the heart demands the heavenly manna of the old songs. It's not so long ago that the realization came that there are no new songs; that a song, like a proverb, to be truly great must have the approval of unnumbered people through a long period of time. Every time a national song is sung it becomes greater, there adheres to it something of the sentiment, the emotions of the singer, so the solo becomes equivalent to the mighty chorus. Call this fancy if you please, but I never alone listen 
to a solitary bird song,-I am one of a vast audience, and the singer is one of a vast choir invisible. $\mathrm{Be}$ this as it may, surely the quality of bird song is so fine it appeals to the finer sentiments of our dual natures like a voice from the vanished years. We are all human, and when we hear Joseph Addison approving of the music of some of our bird friends, the approval is some way divided between the bird and ourselves; the bird as a good singer and we as good listeners. I herewith give an Addison letter that you may see what he thought of the song and the singer. This letter, written in the year I708, by Joseph Addison, to the young Earl of Warwick, whose mother he afterward married, is full of a charm that time has not dimmed. It reads as follows: "My dearest Lord:

"I can't forbear being troublesome to your Lordship while I am in your neighborhood. The business of this is to invite you to a concert of music which I have found in a neighboring wood. It begins precisely at six in the evening and consists of a Blackbird, a Thrush, a Robin, and a Bullinch. There is a Lark that, by way of overture, sings and mounts till she is almost out of hearing, and afterward falls down leisurely and drops to the ground as soon as she has ended her song. The whole is concluded by a Nightingale that has a much better voice than Mrs. 
122 What Birds Have Done With Me

Tufts and something of Italian manner in its diversions. If your Lordship will honor me with your company, I will promise to entertain you with much better music and more agreeable scenes than you have met with at the Opera."

Addison's appreciation of old friends of ours carries back into the past, a point of view that divorces a real singer from an anatomical specimen. It's a rill near the head-waters of that great river, that disregarding mere drift wood, is now rather generally recognized as one of the living forces of the world-creation's poetry, creation's choral singers.

Joseph Addison, recognized as a thinker of unusual power, of necessity, could not neglect the wonderful house of life in which he lived and had his being, and consequently investigated bird life and had his soul thrilled with bird music; music way beyond man's imitation of something to be heard where dawn winds laugh and the trees of the field clap their hands. It was an old song that the Blackbird was singing in those days, but what Addison heard was inferior to what Frances Ledwidge heard and makes us hear. Listen:

"And then three syllables of melody

Dropped from a Blackbird's lute and died apart

Far in the dewy dark. No more but three,

Yet sweeter music never touched a heart

'Neath the blue domes of London." 
This humble Irish poet, this inspired Nature lover, this sweetest singer among sweet singers, shortly before making the supreme sacrifice for his country, put this echo of himself and the song of a bird into the heart of humanity.

Lieutenant-Colonel John McCrae, "when in the thick of it," saw Flanders' fields with the eyes of a seer and sweeps the heart-strings of humanity with a "Swan-song," the like of which was never written, calling upon the world's heroes for help, not for himself, but for his cause,- - that he might sleep where Poppies blow in Flanders' fields. In the little poem of fifteen lines, two and a half are devoted to a great song that is being sung to terrific accompaniments:

\section{"And in the sky}

The larks, still bravely singing, fly Scarce heard amid the guns below."

What he hears is no madrigal, a mere expression of sylvan bowers and love and gaily flitting hours, it of necessity must have been a heroic battlesong, like the great ones "whose footsteps echo through the corridors of Time."

In the sky of the soldier's mind, in his better moments, there often came the shadow of passing wings and his soul at such a time was often enthralled by some dominant bird song - the phantom of a silent song for which he listened though 
124 What Birds Have Done With Me

he knew he could not hear it. He put it into his marching songs and it shortened weary miles - a spiritual urge, a voiceless benediction from vividly remembered yesterdays:

"There's a long, long trail a-winding,

Into the land of my dreams,

Where the Nightingales are singing,

And a white moon beams."

Not only to marching men, but to the world weary, the lonesome, the man away from home, has the singing of wild birds come with an inspiration and an ever-present help in time of need. This story seems to confirm a general belief. A man whom unmerciful disaster followed fast, found himself so beset with difficulties that he made up his mind to go throw himself in a river from a bridge; when he got there, he found a bunch of boys in swimming at the very place where he was going to end it all. Without the least modification of his resolve, he hid himself in some bushes and settled down to wait their departure. Suddenly a brown bird, a Brown Thrasher, in a tree almost over his head began to sing, and the song gripped the soul of him, snatched him out of hell, as he lay there grovelling with his mouth in the dust. City bred, he had never listened to a bird song-had the utmost contempt for those who did-and now when he could not help him- 
self, wonderful waves of melody had taken him captive, had lifted him up in an indescribably tender embrace and made a new creature of him. It was no common bird song, it was a pean of victory over the redemption of the most miserable wretch beneath the blue sky. Almost before he knew it, he was crying over the vanquished cur who had come down to the river to end all and the next instant, he was laughing and rejoicing with the man who was going back to town to win his own place in a world that was not all discord. Both beauty and melody are divinely ordained to bring about the salvation of the lost and they frequently unite in the wild bird and the superhuman song.

In the general narration of what birds have done for me, I recall a case when a wandering voice came to me with inexpressible cheer and comfort,-shepherding, so to speak, a lost sheep -at what age does a human creature cease to be a lamb and become a sheep, - is it seven? Lured by a cow-bell on the neck of a frisky creature that possibly was in training to jump over the moon, I had wandered from six to nine o'clock, and finally lost my way, in a forest where fences were unknown and cattle ranged for miles. I was soon to recall snatches of conversation that neighbors had carried on with my father. We children were not allowed to hear much of the talk, always 


\section{I26 What Birds Have Done With Me}

being sent out of the room. Old Clesen Smith had figured it out, if "it" kept coming at its present rate of speed, "it" would hit the earth in just three days. Grant Culver was sure that if "it" did not change its course it wouldn't touch his house but might tick his barn, ten rods to the east, and that was fully covered by insurance. Old George Walker said that if the Bible was true, there would be signs to give up our leases-he said this with a sly chuckle-that the world was so given over to wickedness that nobody had kept any look-out for the signs of the second coming and he had a notion that things would go on about as they were for a little time longer. George was a friend of mine, and I don't care if I did listen at the key-hole. Ezra Wilson had heard that over at the Seventh Day Settlement, they were airing out their ascension robes, and getting ready for the second coming. We children heard what Daddy said, for he had a big, carrying voice that would leak out of a little room and besides, he kept talking when the neighbors were going down the path. He just told them not to be fools, and said that if old George Walker was right and the world was much more than six thousand years old, that would simply strengthen what he had been telling them, that no such catastrophe had ever happened in the past and that was a very strong assurance that it was not going to take 


\section{The Song and the Singer}

place now. These simple people were afraid of something, but it was kept from us and we did not have the slightest notion of what all the talk was about. Jerry Norton had called to us from way out in the lake, where he was fishing, that we had best sharpen up our tomahawks as there was going to be an Indian war. Nobody believed him, as a rule, but I think we concluded that he was telling the truth and began to think Indians.

Now I was in no way prepared for what I saw, when coming out of a thick growth of poplars on the edge of a little marsh, I saw a great fiery body with a long tail of flame in the midnight sky, rushing straight toward me. Clesen Smith was no fool and he had said "it" would come in three days - and that was three days ago. All the world was more or less afraid of that big comet of sixty years ago; is it any wonder that a lost child in the woods-lonely and afraidshould have been simply terror-stricken? A mad panic seized him and he ran like a frightened hare through under-brush and vines and brambles that scratched his face and tore his scanty clothes, insensible to every feeling except the desire to put all the space possible between himself and the awful thing that was going to hit the earth right near the poplar swamp where he first saw it. He kept it up till, panting and sobbing, he fell to the earth unable to proceed a single step 


\section{I28 What Birds Have Done With Me}

further; his race was run. How long he lay there, he never knew. He was roused out of the sleep of exhaustion by a voice, a calm, steady, deliberate voice, clearly unafraid of what was going to happen to the world, saying over and over again: "Whip-poor-will, Whip-poor-will, Whippoor-will"; and it was a disembodied voice, bird, animal, or human, he could not tell, but comforting as the hand of his mother stroking his perspiring head. He wanted to get closer and as he approached, it retreated; he forgot everything else, it was all swallowed up in the desire to get closer to the wonderful comforter. Ahead, he suddenly saw a hole in the woods; they were coming to a clearing and in a moment more he was in a path that seemed familiar, and the next he knew there was Adolph Buzze swinging down the path toward him, singing a French song. When he got hold of his hard, strong hands, he held on, not saying very much, but just holding on. "Oh! bird come every night. Some joke about whipping-Will; was no Will to lick. Oh! yes, about comet-that big joke, too. Mighty God, scare foolish children with Mr. Longtail, then he say Mr. Fire-eater, go chase yourself and he go, easy 'nuf."

Good men, through my adolescence, on revival occasions were in the habit of trying to uncover hell, an anti-climax after the big comet, and 
though they tried to make us hear as well Heaven's last trumpet shaking the world below, what I really heard was "Whip-poor-will, Whippoor-will, Whip-poor-will." Dear kindly voice that in my distressed childhood led me to Adolph and the home pathway where the cows had come of themselves, been milked, and were chewing their cuds as unmindful of the fiery comet as Adolph himself. How often in after years did the memory of all this come to me on silent wings with healing for spiritual ills and guidance to the green pastures and still waters where souls are restored.

Woodrow Wilson has performed a stupendous service for humanity, the greatest conceivable service, when he liberated among selfish mankind a devotion to principle for which men were glad to give their substance and their lives. Among the clangor of sordid aims, the snarls of defeated profiteers, the vituperation of political enemies, one clear voice has risen, saying over and over again the same thing: the weak must be protected, the world made safe for the individual. What is to be the power to bring this to pass? The greatest in the world-spiritual force,-the only power that is adequate, on earth, to remove mountains of ignorance and selfishness. If you will, a dreamer is making a dream come true, preparing the world to see beauty that it has never seen; to hear music that it has never heard. Natural 


\section{What Birds Have Done With Me}

beauty and natural music are so inherently spiritual that they can only be spiritually discerned. I am using this word spiritual in no narrow ecclesiastical sense, but in the wide sense of oneness, with the only forces that, concealed by the temporal, are eternal. Brother, mine, the poor temporalities of life have prevented you from seeing the singer and hearing the song.

Returning in the night, after an absence of more than four months, it seemed most fitting that the insistent reveille of the Loon should usher in the dewy freshness of the late April dawn, and be the fore-runner of a host of familiar voices that, also, woke the echoes of many a dim and far-away spring morning. I found myself not only listening to the cry of this particular Loon, but to every cry of the kind I had heard since childhood. It almost seemed as though these half-forgotten voices lived again, or else I was hearing the echoes of those long since smothered in the silence of death. When I first heard it, it seemed nothing less than the terrible voice of some unknown wild beast, or the lament of a lost soul in torment, and long after I knew the sound came from a bird and was possibly a love call, certain sub-conscious echoes, in my childish mind, would cause fear to show a leering face.

The next voice was that of the Mourning Dove. Sweet and tender as the dawn, yet seemingly 
charged with an inexpressible plaint, an eternal lament, fitting it beyond any other wild thing, to tell its woeful story o'er and o'er amid the wreckage of old battle-fields. Indeed, there seems no personal element in it-if it be grief at all, and from having been accustomed to think of it as expressed in exclusive lament for that fine lover, Cock Robin, dead before his time, a little stretch of the imagination, and lo! a universal lament over the wretchedness of humanity.

Optimism is born again at the sound of the cheery voice of Cock Robin himself, very much alive and seemingly well satisfied with the world and life as he finds it, or at least putting up a splendid bluff. Mr. Woodpecker, I hear those sounds you are making, two blocks away, using a telephone for a drum and as an Irishman might say, while you are waking the echoes, you are not saying a word.

The Song Sparrow, everybody's darling, is next; swinging back the cob-webbed doors into the music room of one's heart of hearts.

Ah! I hear you, Mr. Red-Winged Blackbird, in the willows down by the lake, and your song is liquid sweetness, long drawn out, a joy forever; a thread of gold running through the years, a tinkling melody, not of the earth earthy.

How good it seems to be at home; how inexpressibly good to be at home with all these voices of Nature. 


\section{CHAPTER XII}

\section{THE LOVE ELEMENT IN BIRD PROTECTION}

The poet Bryant wisely calls attention to the fact that it is to those who held loving communion with Nature, to whom she speaks and for whom she has a message in all the changing conditions of human life. It is equally true that to those who do not love her, she is as silent as the Sphinx. Love is the key to the great realm of nature-the wonderful house of life.

In a profound reverence for life, some of the vanished civilizations have mighty lessons to teach the man of to-day, who is dominated by his lust to kill. Egypt had its "sacred Ibis" and anyone killing it was guilty of murder and the punishment was death. Why was it thus highly esteemed? Because in the old days " $\mathrm{Ra}$ came down from heaven and said unto one of the gods of Egypt: 'Thou art in my place and thou shalt be called Theth, the representative of Ra.' Then the majesty of the god of Ra spake unto Theth, saying: ' $I$ will make something shining and resplendent in the under-world and in the land of 
The Love Element in Bird Protection 133

the deep. And I, also, give unto thee power to send forth thy messengers.' Thereupon, the Ibis, the messenger of Thoth, came into being. The miraculous bird was beneficent in all his ways, destroying locusts, scorpions, serpents, and the noxious creatures which infested the country and its searching out and destruction of these enemies to the growing crops and to man himself led to the profound respect which this messenger of a god enjoyed."

Theth, inventor of astrology and mathematics, the god of wisdom and magic, the one among them with divine power to restore the dead to life, and the Ibis became one and inseparable. He was often pictured as having the head of an Ibis, even when restoring the dead, and the picture of the bird is, indeed, the hieroglyphic of his name as well as the hieroglyphic for "the soul." Is it not possible that the weakness in the love element in our regard for bird-life will help explain why this all seems such nonsense to us. Nevertheless, much might be said in support of the belief that the bird is the gift of God, and in very fact inseparably associated with man's well-being on the earth-beneficent messengers meriting loving reverence. Having written thus, much of what will doubtless sound like ancient fable, may I be permitted to add a parable of the 1919 model?

Professor Blake, returning from a morning 


\section{What Birds Have Done With Me}

walk brought in his hand the dead body of a small bird, looking strangely like a Canary. His three children gathered around him and he explained to them that it was an American Goldfinch and not a Canary, though sometimes called one. Instantly the children lost interest when they found out that it was not a Canary and they were hunting up their playthings; and it is doubtful if they heard him as he went on to tell them that the dead bird belonged to the family of Fringillidæ and its correct name was Spinus tristis. Certain it is, that Spinus tristis had had no place in their affectionate little hearts. Finding that the children had no further interest in his find of the morning, the Professor tossed the dead bird out of the window, as a breakfast for the family cat. Just at that instant his wife came flying into the room with a bird-cage in her hand,- "Oh, John, Dicky is dead," she cried. Toys are discarded and every child takes up the wail, "Dicky is dead" - and it is a tender husband and father whose own eyes are misty as he attempts to comfort his weeping family. Later on, he makes the little coffin and he and his wife stand at an upper window while the children conduct funeral services in the garden below.

There is a stern pressure of the clasping hands of the parents when Baby comes to make the prayer. $\mathrm{He}$ is actually kneeling by the open grave 
The Love Element in Bird Protection 135

and his troubled little face is lifted up to the blue dome of the sky as he says: "Our Father in heaven, hallowed by thy name,' Dicky is dead, we are planting him in the garden, so please, 'Our Father in heaven, hallowed by thy name,' to keep him from taking cold so he can sing to us like he used to, when we come to heaven looking for him. Amen."

Why the difference in the effect of the death of these two birds, looking so much alike, on this family? The answer is not far to seek. In one case, they had little knowledge and no affection. In the other they had intimate knowledge and great affection. After all, it is the love element that we must depend upon to save the remnant of vanishing wild birds.

There is a profoundly philosophical statement to the effect that "things seen were not made by things that do appear." In other words, back of the tangible thing before us, are unseen and often remotely operating causes. In every life are what are called red-letter days-something sharply defined, a new point of view, the instantaneous dominion of a strong emotion. Detachments of gray mist are deploying across a hillside in the early dawn of a May morning, after a night of rain. The big guns of the storm clouds had put on their barrage and their receding roar could be heard across the lake to the southwest. 


\section{I36 What Birds Have Done With Me}

The wind had fallen to a zephyr, the zephyr to a sigh and the sigh had faltered and died and the tremulous leaves of the poplars waited orders. Suddenly, out of the strangeness, out of the grayness, a part of the waiting silence, taking possession of the universe, a red bird, a flame of fire, adding the visible presence of God to the mistenclosed tabernacle in the wilderness. For this cause, the bare-footed boy had come into the forest-he had mistakenly thought he had come in search of cattle-for he was a worshiper before it would have been possible to put the shoes from off his feet, had he had any on. Worship is a mysterious cradle in which love sleeps and dreams and grows strong and is made perfect. It was only a Scarlet Tanager, but it swiftly led him through all the stages and gradations of emotion, and a radiant vision of childhood was transformed into a tangible possession enriching all of life. James Lane Allen and Gene Stratton-Porter have each put their Cardinals into a volume, but my Tanager and the dreams and fancies connected with him are so much a part of the heart of me and the great heart of Mother Nature that prose seems inadequate and poetry itself could do little more than call attention to something beyond it,like allusions to dawns and sunsets. Though the Scarlet Tanager did not make a great poet of me, it put great poetry into the woods and some of 
The Love Element in Bird Protection 137

the very finest kind of blank verse into every-day life. There is no other bird like the Scarlet Tanager in the North woods and if you think it pagan to make a deity out of him, at least enthrone him as a High Priest in the temple of Beauty.

Quite a good many years ago, we had snow on the thirtieth of May, and being out driving with my family we came around the base of a hill, and there before us not a hundred feet away, in a dead tree, were two birds not ten feet apart,-one an Indigo-Bunting and the other a Scarlet Tanager. A little daughter who had been studying the flags of all nations, said they were the colors of the English flag and then we saw them together against the snow-covered hill-Red, White and Blue. Looking back across a war-devastated world where a Peace Conference is now in session, the remote Memorial Day becomes exceptionalmade so by two birds that quickly separated and snow that melted like a dream that all taken together, for a brief moment gave us the colors in the flags of the three greatest nations on the face of the earth-England, France, America.

Next to the Tanager, the Indigo-Bunting is our most beautiful bird. In the estimation of very many, he stands for the cloudless sky, the halcyon, the perfect day. Sky-blue, like truth in which there is no mixture of error, the whole apparel is 


\section{I38 What Birds Have Done With Me}

from a patch of the perfect blue above. As the Eagle is a national emblem so should our weather service adopt this calm serene Blue-bird as the fitting emblem of the kind of weather most desired. As a general favorite, the real Blue-bird scores over the rarer and more reserved Bunting. Five hundred people know and love the Blue-bird where one never saw the other. In the north, the Blue-bird with the Robin is a harbinger of spring and is loved for his engaging ways; winning ways, they surely are, as is proven by the large number of his friends. With the house Wren and Robin, his relations are close and almost confidential with man. The first thing on his return he comes around your home looking to see if in his absence you have provided him with a house, which is his first choice. If you have not done so, he finds a suitable place as close to you as possible, and goes to house-keeping. If your soul is not dead within you, the presence of such a neighbor is looked upon as a general improvement of the whole neighborhood. John Burroughs says that "the Blue-bird has the sky on his back and the earth on his breast." It seems as though he must have the red clay of Georgia in mind rather than the dark loam of Wisconsin. However this may be, the thought is fine, a dear familiar bird standing for both earth and sky. No weather is too cold for the Chickadee, or too warm for the Blue-bird; 
The Love Element in Bird Protection 139

I never saw the first seek protection from the cold nor the second from the fiery rays of the sun. The Blue-bird, beyond any other bird I know, is a bird of the sun-light and will not live in the shade. On the lawn of my home, is a venerable apple tree, the last of a large pioneer orchard. It is partially hollow and principally decayed, but every year it buds and blossoms and puts forth a wealth of leaves that keeps the sun from penetrating to the bole of the tree. Seeing Blue-birds casually investigating the tree, year after year, and never building in any of its numerous cavities, I concluded that it must be on account of the bad state of decay in which they found the trunk of the tree. So I put my latest thing in a bird-house in the deep shade in the center of the tree and the Blue-birds came and looked it over and did a lot of talking among themselves and then took up quarters else-where. Different models of houses were tried but with no success, and then I got a hunch; it's the shade. The neglected house in the tree was quickly moved to the top of a fence post up by the garden, all in the merry month of May, and in no time it was taken on a long-time lease and has not been vacant since.

One year a pair of Blue-birds set up house-keeping about six feet from the ground, in an abandoned Wood-pecker's hole, in the dismantled stub of an old apple tree. Nothing could have been 
more public than the selection of a nesting place. It was on Hotel grounds and not two hundred feet from a tennis court and from the beginning of the nest building to the flight of the brood, people passed constantly and visitors frequently came in crowds. All this disturbed the birds not at all, and it did not require a whole lot of imagination to fancy the proud parents posing the babies for their pictures after they came out of the hole in the tree. It was a beautiful Summer-school where little children, world-weary people born and reared in cities, entered together a kindergarten where the teachers were birds that stood for the earth and the sky.

Time spent in bird study that does not transform the student into the lover is time thrown away. Only spiritual forces can conquer material brute lust and selfishness. London-Bridge can be fiddled down and love can conquer Jungle-land. Just as soon as a large number of people place upon our bird neighbors proper æsthetic valuea value not to be computed in dollars and in cents-but in heart throbs and pure joy-we will be assured that love will bring about the fulfilling of the law.

Nobody does anything in this world worth while except where action is the expression of an emotion, a sentiment not all of the earth earthy. Horse breeders, dairy-men, shepherds, chicken 


\section{The Love Element in Bird Protection I4I}

and dog fanciers and swine growers have a certain interest in the creature that occupies their thought and monopolizes their activities; but I fancy that none of them would care to be reckoned the actual lover of the creature they care for, while on the other hand those who care for birds are proud to be known as bird-lovers. A very learned and somewhat famous educator once wrote me offering the chair of nature study in a school of which he was president and the letter went on to state that people who ought to know, had recommended me as an accomplished ornithologist. I wrote right back and said that there must be some mistake, I was no ornithologist at all, never had claimed to be anything of the kind, and I was glad to be able to state that there was nothing in my past suggestive of King Herod-being only a birdlover.

Just as people are constantly asking you-if you happen to know ten lines of poetry-what is your favorite poem, so people are always asking me what is my favorite bird. The question puts me in the position of a person with a big family being asked which is the favorite child. It being more or less embarrassing, I have invariably tried to side-step it and even now I think I'll have to do the "Lady or the Tiger." There are Mourning Doves and Bronze Grackles; each has had a large place in my heart - which is the dearest dear, you 
142 What Birds Have Done With Me

must decide. Before I tell their story, I wish to call attention to a general law. Intimate knowledge and close association are necessary conditions of real affection. Why the Dove and the Grackle? I have only the one answer; I have known them intimately since child-hood-they are old playmates.

"A burnt child dreads the fire" is the proverb, and an analysis of the why would show that the flame had burned itself deeply into the memory. I not only burned my fingers but my whole hand, and got a live coal into my apology for a shoe in rescuing a Mourning Dove's nest from a burning brush-pile. Never mind about my eye-brows and my eye-winkers, I got the nest out that was just beginning to smoke and one bird lived, my very very first pet coming from the wild. With it perched upon my shoulder, I climbed several steps up toward a kingdom where things fly; it made me want to fly and later when it would make certain little journeys in the world, I would pursue, running like the wind. Panting, breathless, de. spairing, certain it never would come back, it always came straight as an arrow for its perch on my shoulder. Was ever a seven-year-old so envied by other boys, especially after Mourny learned to take a grain of corn from between my teeth, fluttering before my face as it did so? Another trick was to pry open my clinched fingers 
The Love Element in Bird Protection 143

with its bill for kernels of wheat held in my clasped hand. I, alas, had not heard in those days about Mahomet having something to eat in his ear when the multitude saw pigeons lighting on his shoulder to whisper to him, or I might also have gone into the prophet business. It's rank exaggeration to say of any thing that it's worth its weight in gold, but that was my estimate of my pet. It was never caged, but was left free to go and come, and it did both. It found its own kind and might spend a half day in the fields with other doves but always came home to roost. Many a time when bringing water from the well a hundred yards from the house, in the evening, it would come sweeping back and flutter along before my face pretending to be after corn from between my teeth. My older sisters said that I was a sissy and had taught it to kiss me. Perhaps I had not explained all of Mourny's tricks to them. I had been holding bags for a neighbor who had just finished thrashing and a lot of grain had been left around where the thrashing machine had stood and I had salvaged a big pocketful for Mourny. and it was under my very eye having a feast in the open passage-way between the kitchen and wood-house, when coming from nowhere, a strange black and white tom cat launched itself on the unsuspicious Dove and killed it in one second. Sir Thomas clearly thought he was getting 


\section{I44 What Birds Have Done With Me}

some easy meat and clearly was in no way prepared for an avalanche of boy that was on him before he could make way with his kill, knocked his prey out of his mouth and was seemingly bent on squeezing the breath of life out of him as well. The strong legs and powerful feet with their murderous claws made short work of the little hands that grasped the throat of the small tiger, that escaped after lacerating the hands of a child belonging to the foolish human creatures who, for ages, have harbored it. That such things could be in the light of day had such a numbing effect upon him that he made no out-cry, the cat had done that and he had duly contrasted his red hands with the pitiful red feet of his pet, as he took the body out to the garden and buried it before he allowed them to take him to old Dr. Shaw to stop the bleeding. Every Mourning Dove since has been a lineal descendant of Mourny and the wife and daughter, of the man writing this, have heard for the first time since this reminiscence was started, the name Mourny which all these years he had kept hidden in his heart.

A certain Doctor of Divinity here in the South is known as a mighty hunter, and a notice in a city paper said that on a recent hunting expedition, he had to his credit (?) thirty-three Mourning Doves; let those who will call him Reverend Doctor,-to me he is nothing but an old Tom- 
The Love Element in Bird Protection 145

cat, thirty-three times meaner than "Old Black and White Scratches."

Cyclonic conditions had seemed imminent all the morning, but the storm did not break till near eleven o'clock and when it did come it was not a twister as had been feared, but a deluge of rain, a hail-storm and wind of a velocity that cuffed and broke great branches off trees as though in wild sport. A carriage load of people had sought refuge in our house, and when the storm was at its worst and we sat around the living room in almost perfect darkness; some sang and others prayed and we boys thought it a fine lark. Such convulsions of nature are not apt to last long and when all was over and we looked, amid indescribable wreckage of fences and tree-tops and heaps of hail-stones, there was a woe begone young Grackle that could neither fly nor walk but was still very much alive. One of our callers when he saw him said: "Holy Moses, did he rain down?" It seemed a good guess for as no Grackles had nested on the sand-hill a mile from any water, if the storm cloud did not bring him, his presence remained a mystery. First he was called Holy Moses, but later on just Moses,-never Mose. It is not altogether his black attire that suggests the ministerial character, but for a fact, with the possible exception of the Raven, he is the most sepulchral, stately and dignified of birds. Every- 
I46 What Birds Have Done With Me

body agreed that Moses was funny, took life and himself that seriously that it was positively funny just to look at him. When he walked it was the Lord Mayor of London leading a procession to be reviewed by the king, and then Moses was always lame which made it all the funnier. He could lose himself about the grounds, but his dignity, he could not lose. He was supposed to be a young bird just out of the nest when he first came, but soon that was questioned, he had such wise old ways. Those who took the side of youth pointed to the knock down fact that he had not yet learned to fly. In two weeks he was a very important member of the family, in four weeks he owned the place and instead of his living with us, we lived with him. Wescott's Brindle Bull dog attempted to cross our lawn and our dog Carlo, a mongrel but some fighter, went over the top to meet this Hun. It occurred by the back kitchen door and soon all was in wild tumult and Moses forgot himself to that degree that he flew up into a nearby tree-remaining there through the engagement, a kind of a war balloon giving Carlo pointers. When the dog fight was over, he took up his old life and never again was known to attempt flight. To narrate all the queer things he did before a cat got him would make a book, and what I aim to do is quite the reverse. I simply wish. to show that to the general acquaintance 
with the Grackles that I got when driving the ox teams on the breaking plough, is a close and intimate relation with the mysterious King of the Grackles who came out of the storm cloud and made his home with us. We did not capture him, he captured us. I, for one, did not know how much I loved him till the morning when he was not in any of his usual places and Cash Haskins, who was helping plant corn, accidentally stumbled on the remains of a cat's supper on the lawn where we saw him first. Yes, I'm frank to admit that I've always been fond of Grackles and what is more, at least, some Grackles have been fond of me. I presume that when one creature trusts another completely, if you could get at the facts you would find that trust bound up with a certain amount of fondness.

Not so long ago on a misty morning, I was using a scythe among some shrubbery that I did not care to turn over to the tender mercy of a hired man. I found there a Mr. and Mrs. Bronze Grackle and five very callow babies in possession of the grass I wished to mow. I started in gingerly, thinking I would soon be ordered to go about my business, but strangely enough, the birds made no objection to my presence and there was neither distrust nor the faintest anxiety in their usual utterances. Still, I did not realize that these birds were paying me the highest compliment that 


\section{What Birds Have Done With Me}

a wild bird can pay a human creature,-perfect confidence. A stranger came out there to see me on business and instantly there was blood on the moon. I took him by the arm and led him away but turned around and took off my hat to the birds, as genuinely touched as I ever was in my life. Five weeks in a darkened room, when your relation with the outer world was by means of a bulletin, giving pulse and temperature of which you know nothing. The head surgeon starting in at zero, no chance-then, one in ten, in five thousand. Then even; then, on the road to recovery and then, sit up day after to-morrow. But the night before the appointed time, I bribed the nurse to put two pillows under my head, raise the window shade and let me have a look out. It was winter when they carried me into that room, it's spring now and in the park just across from the hospital a pair of Grackles are making a nest. My stately friends had brought the spring and all out-doors, so I could see it from my windownests, new life, called back by two handfuls of straw and mud.

A psychologist of some note has recently put forth the theory that black is not a color and if the mind is concentrated on this supposed something,-that is really nothing,-sleep may be induced. It certainly is of some benefit in some kinds of insomnia. I started to concentrate on 


\section{The Love Element in Bird Protection 149}

Poe's Raven whose color seems black, but black is not a color, so it's nothing; but I never felt quite at home with some-body's Raven so I naturally traded him for one of my own Grackles. I follow him across the lawn as I have seen him walking a thousand times, he out-walks me; I grow weary, lose my way and later waking take up the chase again with the same result. Who knows, perhaps it will be the King of the Grackles who will gently lead me down to my last sleep. 


\title{
CHAPTER XIII
}

\author{
MR. ESAU
}

In introducing my friend Mr. Esau, I concede your right to an immediate explanation as to how a Rose-breasted Grosbeak became the possessor of such an extraordinary name. It's simple enough, which is probably true of all nick names, but we are not to lose sight of the fact that a nick name will not stick unless it has the approval of the majority of one's acquaintances. A Rose-breasted Grosbeak, a hospital case,-the hospital being a big wire cage, on a veranda, - was seen by a young lady and her mother, demurely kissing a feminine caller through the wires and what more natural than for the young lady to exclaim: "I saw Esau kissing Kate and the truth is we both saw"; and as the act and the comment were both repeated, what more natural than for Mr. Grosbeak to become Mr. Esau. Then again, a brother had robbed a brother of his birth-right and in so doing had deprived him of a blessing that included the dews of heaven and the fatness of the earth and love and song, of which corn and wine are the all too fee- 
ble symbols. An air-gun that, perhaps, a fond mother thought would make her future President manly in his tender years, had been the weapon used in the fracture of a wing, and this fracture meant the robbing of the organ-loft of a cathedral tree of a sweet and mysterious musician, intimate friend of Aeolian Harpists and rival of Apollo.

Victory and defeat are often not more than a minute apart and one has a most unaccountable trick of usurping the place of the other. A small boy thrilled with victory as he beheld his animated target falling fluttering through the limbs of the tree earthward, but when within reach of his hand the splash of red on the breast was mistaken for blood, and overwhelmed with remorse and shame, he took to his heels; and it was quite another boy, who knew nothing of the catastrophe, that picked up the wounded bird by the roadside and carried it to his teacher at school and she, figuratively speaking, put a red cross upon him, and had the patient rushed to my hospital for necessary surgery.

Like his great prototype, my Mr. Esau was a cunning hunter and a creature of the field and in addition, I found him to be one of my most impossible patients fighting each and every measure attempted for his betterment, with the obstinacy of a martyr and the long-suffering of a saint. The difficulty was not in applying the starched bandage 


\section{What Birds Have Done With Me}

to the nicely adjusted fragments of the greatest wing bone; the difficulty came in when we attempted to hold the broken wing in its proper place. So to speak, Mr. Esau refused to carry his arm in a sling and if there can be any such thing as silent eloquence, he eloquently announced his unalterable determination to die first. With some feeling akin to what Darius Green entertained for the Wren, my gray matter, plus that of a host of helpful friends, was combined in an effort to out-wit a single broken-winged, improperly nourished mite of a bird, who scored over us as the afore-mentioned Wren did over Darius, in his attempts at flight. A four-tailed bandage, the size of six postage stamps, laid out two and two, with a tape sewed to each corner and holes cut for the legs, when afore-mentioned tapes were criss-crossed and tied over the back, was impulsively called Eureka, but should have been Appomattox, for in less than six hours I found myself kneeling upon the worthless contrivance and humbly proffering my "Catlin" to Mr. Esau and expressing the hope that he would condescend to use my Rush Diploma as his door-mat. Though bull-dog tugging at the bandage would not relieve him of it, it never failed to pull it around enough so that he could not use his legs, and enable him to turn turtle; the sight of his red keel 
uppermost wrecked faith, hope and charity every fifteen minutes.

I had rather be chief cook for a hundred lumber jacks than personal chef for a single caged Grosbeak. Mrs. Rorer herself would have had to work over time to devise dishes that would tempt so capricious an appetite. Potato bugs were out of season and Crickets and Grass-hoppers in Kindergarten classes; Dragon-flies cruising as submarines and June-bugs undrilled for street concerts; the White Grub was my refuge and help in trouble. How he loved them! He would eat a half a pint in a day. It was a banquet twelve hours long and he Fletcherized each individual grub. He would hop about the cage with a fine fat beauty sticking out of the side of his mouth, suggesting a devotee getting the very last whiffs from a quarter inch long cigarette. He would not eat an angle worm on compulsion, or in any other way, and rejecting cherries and lush strawberries, always made believe that he had a well-bred liking for grape-fruit. Hemp-seed he cracked for the sake of the recreation it afforded, having clearly no great liking for the kernel except as it helped to balance his White Grub ration. He never attempted to sing the songs of the tree-tops in his narrow prison-house and how his kind learned of his predicament, I have no more way of knowing 
I54 What Birds Have Done With Me

than I have of what they thought of it after paying him repeated visits. Almost every day he would have visitors, both male and female, coming singly, as a rule, and perching upon his cage for about the length of time that is given to the formal call, and my wife and daughter are positive that they kissed at parting. I take it that the calls were more or less formal, for they never brought him any thing to eat, neither did he ever offer to share his grub with them. I confess to having failed to get any key to the mystery of their communication and yet there is every reason to believe that the misfortune of one of their numbers made quite a lasting impression upon the minds of his Grosbeak neighbors and friends. Proof of this statement will be offered later on.

When the last bandage was removed, it was found that the bones had knit properly and he had pretty fair use of his wing, but it drooped and could not be held in place and extended flight was still a question. For two weeks more this question kept him in Hospital; the last night came, his splendid progress would demand the opening of the door at dawn, returning him to the blessed earth, the mysterious fellowship of all aerial voyagers, - free, free, free! The ways of life and death are past finding out. The dawn came, but the door was not opened, the good wing and the mended one were equally helpless, 
and on the bottom of the cage was a rigid little body, the worthless remains of what we had known as Mr. Esau. Perhaps the eyes blurred a little and the hand was not usually steady when certain rites and ceremonies were being performed that were destined to change Mr. Esau into, not only a stuffed Grosbeak, but a whole sermon on the text, "Who being dead yet speaketh."

Making my annual bird-talk to the village school, shortly after the death of the Grosbeak, I took his skin with me and told his story and let the children of the lower grades not only see but handle the patched-up wing, the only witness called for a time; but in the fifth grade I received a hunch and shading my eyes with my hand I began to look for the guilty boy; after a pretended unsuccessful search, I said in substance: "No, he is not here and if he was I would not point him out, for you all hate him, hate him because he is a robber and has robbed you and me of something of the sweetness and melody of the spring-time and to this there is to be added the hideous blood-lust that is supposed to lurk in jungles." "Children," I continued, "I want you to be very sorry for this boy's mother-poor, poor soul, how I pity her, in ignorance of his real character,-sneaking, cowardly, pitiless,-she is doubtless hoping, believing, praying that her son will turn out a splendid man, a leader of men." I 
156 What Birds Have Done With Me

doubtless said too much, but Mr. Esau's shadeI'll not say skin, for ordinarily they are denied the power of speech-said even more and the children were as eager to get hold of the killer as they had been to handle the skin of the thing killed, and I am quite sure it would not have been anything like as gently.

Bright and early Saturday morning following, the girl said there was a boy in the outer office to see me and when she sent him in I half caught my breath, for my hunch was true and I had selected the right urchin in No. five School-room. Though scarcely ten years of age, he was quite an old friend of mine, and I patted him on the shoulder and for the fortieth time, I reminded him of the bitter fight he put up at the age of five when I vaccinated him. However much he had been in the habit of rewarding my reminiscence with a pleased little grin, no ghost of anything of the kind was on duty nor could be called from afar.

Clearly Billy was in trouble, and the world over, the deeper the trouble, the more difficult it is to get rid of the perilous stuff that weighs upon the heart. He was over-whelmed by a mountain that stood squarely across his pathway and could only say when I asked him what the matter was: "Oh! nothen Doc, - that is, nothen much." He evidently found the room warm and I told him 
to take a seat by the window till he was ready to talk. A surreptitious glance revealed the fact that Billy's chin was trembling and he had frequent furtive uses for his dirty little handkerchief, so swinging around I delivered a "mercy shot""Don't feel bad, son, I 'll never tell any one that it was you who shot the Gros-beak."

I do not intend to be thought flippant in the presence of real grief when I say that before you could say "Jack Robinson," Billy had hold of my hand, sobbingly demanding that I "Cross my heart and hope to die." As there were still some duties and pleasures not worn entirely thread-bare, I demurred at the latter half of his demand and we compromised on the first clause to his entire satisfaction. No possible question of the soundness of Billy's conversion or the honesty of his desire to become a Billy Sunday among Junior Audubon Evangelists. Before many audiences in many parts of the country, thus did Mr. Esau win his victories so that if ever canonized and given a new name it will be entirely proper to call him after some great evangelist. I walked part way home with Billy and at the turn in the road this was his parting confidence: "If you had told, I don't 'spect it would have made so much difference with the fellows, but I know the girls would all 'spized me."

A year after the long struggle with Mr. Esau, 


\section{What Birds Have Done With Me}

the one who had carried it on was himself a prisoner on the same veranda, not in a cage but a wheel chair, contrary beyond question but not so much so as he might have been had it not been for the flittering ghost of Mr. Esau acting as a horrible example. Grosbeaks are shy birds of the tree-tops, who reverse the conduct of good little boys by being more often heard than seen, so it becomes difficult to imagine my surprise to have one come into the ornamental wood-work at the top of the veranda; and here follows the proof that they had not forgotten the poor captive of the preceding year; a maid brought out a canary and hung the cage under the veranda and coming from nowhere almost instantly, there was a Grosbeak on it clearly looking for Mr. Esau. Singly it seemed as though each Grosbeak visited the cage once only and there were no kisses at parting. Dickey was to them no yellow peril and there was neither race war nor affection between them,-only the Alps of an impassable indifference. Coming back to my own "vine and fig tree" from a hospital that for me had been down close by the gates of death, it is impossible for me to make any one understand how much the Grosbeaks did for me when it became evident that among humans I was the one to be trusted. All that Spring, always excepting Chickadees, no other birds had ever been so intimate, almost confiden- 
tial, - if such a word can be used in connection with a bird. They Fletcherized their food, made love, fought their little battles, told their stories and sang their songs, as though I was quite one of them. To some it will seem like extravagant sentiment, even when considered in the light of the thick coming fancies of a sick man, but to this day I feel that I shall stumble and lose my way if I attempt to tell all that is in my heart of the ministry of these wild bird friends who visited me when I could not go to the forest where Spring and Summer meet.

"Ah! who shall lift the wand of magic power, And the lost clew regain?

The unfinished window in Aladdin's tower

Unfinished must remain." 


\section{CHAPTER XIV}

\section{STUPIDITY STREET}

In an editorial having the caption; "The Strong Things in Life," the "Times-Picayune" of New Orleans, quoted the following lines from the poems of Ralph Hodgson and I know of nothing to be found elsewhere that is a more remarkable epitome of the whole question of "Bird Protection."
"I saw with open eyes
Singing birds sweet
Sold in the shops
For people to eat,
Sold in the shops of
Stupidity Street.
"I saw in a vision
The worm in the wheat,
And in the shops nothing
For people to eat;
Nothing for sale in
Stupidity Street."

Here, in a nut shell, is the whole matter; it is stupid to kill song birds for food, they are the 160 
real,wardens of all growing things, they stand between the worm and the wheat field; kill them all and there will be nothing for sale in "Stupidity Street." There is no escaping the inference of the poem. The man who uses a song bird as an animated target, destroying an insectivorous bird for a tidbit to tickle the palate of a would-be epicure, may not be a criminal, but alas, is one of a multitude-all of whom live on over-crowded "Stupidity Street." Follow the people home who are guilty of wantonly destroying our vanishing wild life, and you will find, with scarcely an exception, that they all live on Stupidity Street. If I were a devout churchman, I would suggest this addition to the Prayer Book: from the besotted ignorance of "Stupidity Street," Good Lord, deliver us.

Here is a very sad case; a beautiful, very beautiful church, to which the waves sing their finest battle and love songs and the leaves of the LiveOaks tell their secrets, and wild-bird singers on the outside outrival the best efforts of the human choirs within, and the church is called "The Church of the Redeemer." There is a Rectory and a Rector, everything quite proper, and all located on Stupidity Street-for the Holy man is a killer of insectivorous birds and no voice has been raised against him in "The Church of the $\mathrm{Re}$ deemer." If the man of God does not know that 
162 What Birds Have Done With Me

a Dove is worth more to agriculture to-day than for sacrifice in the old days, and more for æsthetic reasons than for pie, he should go to school again and be re-ordained.

It would seem that the church whose altars, through dim, dark and dreadful ages had dripped with the blood of young Pigeons and Doves could do no less, by way of expiation for that bloody past, than turn all the power of its efficient organization to conserve what is left of wild-life.

The sacred part of a temple has, of late years, become associated with bird protection-sacredness like a thread of gold clinging to our tardy efforts to save our vanishing wild life. Those enlisted in the Grand Army of Bird Protection are not Crusaders, struggling to rescue from the unbeliever a Holy Sepulcher; they are the Master Builders for the coming years and their sanctuaries will be filled with life and song:

"Till the sun grows cold, and the stars grow old And the leaves of the judgment-book unfold."

He who builds for the future, struggling to improve conditions affecting all the people for all time, is engaged in the only holy war that has ever been waged in the history of mankind. A stainless soldier is the one who fights for principle and is a victor glorified compared to the one 
whose motives are sordid or corrupt. The "City of Refuge" and the "Horns of the Altar" are some way, more or less closely associated with the "Bird Sanctuary," as we know it to-day. It is perfectly wonderful how soon the wild things come to know where they are safe. When a misguided politician in my own county had an open season on the remnant of our prairie chickensprotected for years-the amazed and terrified birds collected on the Maplewood Audubon Reservation-our farm-and walked about the lawn like domestic chickens, a wounded bird coming with the rest, and actually died under my office window. Only the other day a beautiful golden woodpecker, having been shot by some miscreant, came back to our Sanctuary and died upon my doorstep and the blood that dripped from step to step cried out in mute protest against the evil doer who kills for sport, fixing upon him blood-guiltiness; and I saw the stain upon my doorstep magnified into a stain upon the land that fails to prevent the shedding of innocent blood. We ask nothing less than America as a vast Sanctuary for song and insectivorous birds.

That there is no difference between North and South except in the matter of roasting coffee and whether we shall have cold bread or hot biscuit for supper, I am sorry to say isn't quite true, for there is a custom in the whole South of shoot- 


\section{What Birds Have Done With Me}

ing song and insectivorous birds that goes back to the first settlement of the country and the professional man, the business man and the negro, with his three dollar gun, are all defying the federal law and are active as ever in bird destruction. Bird protection has utterly failed to get the moral support of the best people in even fairly progressive cities and where this is so, what can you expect of lewd fellows of the baser sort in little villages and back country places?

Biloxi, Mississippi, long a winter resort for Northern people, ought to be more progressive than the average city, and yet after five winters of persistent work for bird protection, talking in all their schools and writing articles for the city papers, I am frank to say I can see small results. The same paper that published my protest against killing Mocking-birds, published a vitriolic rejoinder from a woman who attempted to justify the killing on the ground that she preferred strawberries to Mocking birds. Nothing that I have ever written about birds has been refused publication in city papers and the schools clamor for more talks - they could not be worth less than they cost-and I am called the "Bird-man" and "Bird's Attorney" and my acquaintance with the children of the public school is extensive, but I am assured by good lawyers that no jury would convict were $I$ to have a person arrested for viola- 
tion of the Federal law, whatever the evidence against the prisoner.

I am going to take the public into my confidence and say that the lady of whom we have rented apartments for the last five years is a good friend and I felt pretty sure that I had made one convert when she had her ten-year-old son, last winter, throw away his air-gun, but on our return in December this year, I found she had given him an ante-Christmas present of the largest and best air-gun on the market and he and his little chums were killing birds, as their fathers had before them.

There are exceptions to all general rules but generally speaking so far as economic and æsthetic appreciation of birds go, I am forced to locate even my friends on that street whose name is the name of this chapter. On this point I want to quote from an account of a brief visit to an interior town twenty miles from $\mathrm{New}$ Orleans where for four days my friend, Creswell J. Hunt, beginning on February 20th, I9 I8, took a bird census. The deep, dark and awful ignorance that he encountered-every solitary soul living on Stupidity Street-is almost beyond belief. Here is an extract from his report that speaks for itself. "While the residents of southern Louisiana seem, one and all, to have a great affection for the Mocking bird, this species seems to be about the only 


\section{I66 What Birds Have Done With Me}

one for which there is any æsthetic feeling. Other birds appeal to them entirely according to the quality of the bird's flesh and this makes the work of the Department of Conservation very difficult in enforcing its laws for the protection of the insectivorous birds. These people have shot Robins and Wood Thrushes and Vireos and King-birds all their lives and it is difficult to explain to them why they should stop it now, and still harder to keep them from killing these birds. Mr. A. E. Manint, the Department of Conservation's agent in St. Tammany Parish, has done remarkably good work in protecting the birds in his territory and, at the same time, has kept the good will of the people. He has been diplomatic, and from what I saw, it appears that most of the people like him and respect his authority.

"People with whom I talked knew the birds by local names-to me entirely new names-and in many cases it was difficult to tell what species they were talking about as their efforts to describe the bird's appearance were often very misleading. For instance they told me that I should be there a little later when the "Pops" came. Their handsomest bird, they said, was the "Red Pop," while the "Blue Pop," and the "Green Pop" were also beauties. I later found that their "Red Pop" is the male Painted Bunting or Nonpareil, while their "Green Pop" is the female of this species. 
And the "Blue Pop" is the male Indigo Bunting. Then they told me about the "Big Caille"(pronounced Big $\mathrm{Ki}$ ) - the game bird par excellence-a bird that feeds upon the magnolia seeds; a bird whose flesh some of the most famous French chefs had pronounced the finest eating in the world. And then there was the "Little Caille" and the "Black Caille," both shot along with the "Big Caille," but the flesh of the "Big Caille" surpassed them all. From the descriptions given me I decided that this "Big Caille" must surely be one of our Thrushes, and I later found this to be correct. The "Big Caille" - the most famed of all the game birds - is none other than the Wood Thrush. I have always heard the Wood Thrush praised but never from this standpoint. I have heard the Wood Thrush proclaimed the finest singer in North America. No doubt, with us, the species ranks foremost in æsthetic value. To many of us Northerners, it is indeed the bird of birds. It is, perhaps, the last bird we would care to slaughter. But down around Mandeville, they love the "Big Caille"-when browned just right and served upon the table. And there is perhaps more hard feeling against the Department of Agriculture for prohibiting the killing of the Wood Thrush than there is about the protection of any other bird.

The Olive-backed Thrushes are killed under the 


\section{What Birds Have Done With Me}

name of "Little Caille" and the Cat-bird, under the name of "Black Caille."

Louisiana has one of the best State Conservation Commissions, but I am a great believer in the long arm of Uncle Sam, whose officials are independent of votes and in spite of some very excellent work done, a raid the other day gathered in a negro with a barrel of pickled Robins, and fifteen whites, among them deputy sheriffs and business men. Though the state officers do their best, no one in that bunch, possibly excepting the colored man, will get a fine calculated to make any one sit up and take notice. The migratory bird not being the property of any state is very properly the ward of the Federal government and with all possible assistance from state organizations, its protection must be brought about through $\mathrm{Na}$ tional intervention. As an Irishman might say: "The Western Front is in the South" for the great battle to make the whole country safe for song and insectivorous birds will be fought there and efforts to conserve and protect cannot long continue when one-half the territory is being swept and combed by hunters who kill everything that flies. The Street must be taught the sweetness of bird-song, the utter shamefulness of robbing nature of her most beautiful and attractive forms of life, for in exquisite coloring many flowers are wingless birds and many birds only winged flowers, 
plus their song. To take birds out of poetry would be like taking tune out of music, - nothing left but idiotic jargon.

Birds are poetry per se and cannot be replaced by other living creatures in poems where they figure, without turning fine poetry into caricature. Here is the proof of the above statement; I will first give Tennyson's Poet Song, then caricature it by simply putting an animal in the place of the bird.

The rain had fallen, the Poet arose,

He pass'd through the town and out of the street;

A light wind blew from the gates of the sun

And waves of shadow went over the wheat,

And he sat him down in a lonely place

And chanted a melody loud and sweet,

That made the wild swan pause in her cloud,

And the lark drop down at his feet.

The swallow stopt as he hunted the bee,

The snake slipt under a spray,

The wild Hawk stood with the down on his beak,

And stared, with his foot on the prey.

And the nightingale thought, "I have sung many

songs,

But never a one so gay

For he sings of what the world will be

When the years have died away."

Beginning with the last two lines of the first verse: 
That made the wild Ass pause in her race And the frog drop down at his feet.

The old bear paused as he hunted the bee, A snake slipped under a spray

And a rooster stood with the down on his beak And stared with his foot on the prey.

The Moo-cow said, "I've lowed many a song But never a one so gay

For he sings of what the world will be When the years have died away."

There is still worse caricature than this, the worst imaginable; instead of the music of the wild - the choir made invisible by the boughs of a venerable brotherhood of trees, you send skulking through these dream haunted shades, the man with a gun, the mean brother of a wolf who being able to comprehend beauty, destroys it; able to comprehend music, seeks to silence it foreverlet us pillory forever that libel on God's creatures.

Let me whisper it; the people on the Street are ignorant,-deeply, darkly, densely ignorant. They don't know the first thing of the laws that govern the world in which they live and move and have their being. To them the house of life has not only had the shades down and the blinds closed, but it has been barred and double pad- 
locked. Nobody on the Street has sought to find a key where it is to be found, in the origin of life itself. All life has a common origin, an invisible cell-protoplasm. Countless billions of different creatures live on the earth, in the water, and in the air, they are all struggling for existence, and each uses the more or less feeble spark of intelligence implanted within it. Now there is not a creature on the face of the earth, the huge elephant and the tiny aphis that destroys a rose leaf, that left to breed unchecked would not crowd everything else off the planet. The people on the Street know nothing of Nature's marvelous fertility and power of reproduction. The human mind staggers in attempting to grasp this appalling thing. Linnæus, the great naturalist, studying the so-called "plant lice" found that in one year a single aphis would produce a quintillion of descendants. How do you write a quintillion using the English method of enumeration? Write the figure one and after it thirty zeroes. The second year, from one single aphis you would have a number of descendants that to represent, you would have to write the figure one and sixty zeroes. Thus from a creature so small that you can scarcely see it, if all its young were allowed to live and breed, in a very short time, there would pile up a loathsome mass of aphids greater in bulk than the world itself. Malthus was right; 


\section{I72 What Birds Have Done With Me}

all forms of life, unchecked, breed to destructive numbers. That life may be, all forms of life must be held in check by their natural enemies. If the people on the Street knew this and the additional fact that the bird is the check upon the noxious weed and noxious insect, they would conserve rather than destroy. It is worse than stupid to kill our bird friends to-day-it is criminal. Whole species have been exterminated, many others are on the verge of extermination, and all species are frightfully depleted, and when all are gone, life itself will quickly pass with the flutter of the last wing.

Gone-This little word of four letters may be compared to a gray wall shutting out the sunlight; a vast desert, where life has been and is not,-a desolation, a haunting memory - the sadness of an irreparable loss. There is the sadness of farewells in the recollection of trackless forests, swept by the destroyer, from the face of the earth, and with them so many of the wood-folk have gone forever. The cultivated field, the populous city, are not places where mother nature may be seen and studied at her best. Sylvan dells, sweet songs, gliding dryads, and dancing fairies are not to be found along the desolation of paved streets. Scores of the dear familiar neighbors of my childhood are gone forever. Across the dawn, I look in vain for the strong, swift sweep of countless 
wings. The great flocks have gone never to return. This, of itself, is a reason for conserving what is left, gathering up the fragments and protecting them, that species may not be utterly exterminated.

Yesterday we were all for slaughter, but we grow frightened to-day, in desolate places from which teeming life has gone, and the hopeful signs of the times are to be found in waves of bird protection and bird legislation sweeping the land. Yesterday, the "Wild life refuge" - the sanctuary, lived only in the imagination of a few dreamers; to-day the dream has come true and the people of these Sovereign States are demanding preparedness for the efficient protection of the pitiful remnant of the "Wild Life" before all is forever gone.

The famous French publicist, Emile Boutroux, in an article on the idealism and statesmanship of President Wilson, gives a view of its comprehensiveness that is wonderful and I know of nothing else that has ever been written that could be adapted to explain my notion of an all-reaching bird protection that will protect. Here is the quotation above referred to: " $\mathrm{He}$ is, above all, desirous of thinking, not in East-American terms, nor in those of the South, the West, or the North, but in all-American terms. His idealism combines what the diverse populations making up the United 


\section{I74 What Birds Have Done With Me}

States have together contributed to the national spirit; the Puritan notion of duty and responsibility; the generous and humane democracy of the Mississippi Valley; the independent, equalityloving, though conservative, spirit of the South; and the practical activity of them all." In another place he says: "It was not the will of an individual, but that of a whole people which, conscious of its ability to accomplish any end submitted humbly this omnipotence to the authority of the moral law and of the ideal."

In bird protection, I see what, in effect, will be a League of States-the whole preventing any one state from laying violent hands upon and destroying what is the property of all the states;bird-protection; "Of the people, by the people, for the people." And when that glad day dawns, "To Rent" will be in every window on "Stupidity Street." 


\section{CHAPTER XV}

\section{JAYS AND CROWS}

By common consent the birds whose names stand at the head of this chapter are members of a most disreputable family and are sure enough undesirables and should be deported to that excessively hot and waterless region from whence they came. It's as clear as mud that black and blue are the colors of assault and battery and assault and battery is a flourish, common way down in the dregs of society, where laborers fight and drunken brutes whip their wives and eyes are decorated with the colors of the Jay and the Crow. Not everything can be allowed in the best society and, it will scarcely permit the bare mention of anything so coarse and common and Bolshevist as blue marauders and black robbers. Believing every one innocent until proved guilty is reversed in the case of the prisoners at the bar, who are required to prove their innocence after being arrested on suspicion and tried before prejudiced juries. As their attorney, though without a retainer, I shall stand upon the rights of my clients 


\section{What Birds Have Done With Me}

to a separate trial and to summon essential witnesses at any cost with usual adjournments taken in their absence.

If the court please, I demand the dismissal of the case on two points, the first of which is that there is no evidence of guilt, or even serious misdemeanor against the defendants, and the second, that the plaintiffs have not been made to put up security for costs.

I object, Your Honor, to excusing the plaintiffs from the usual security for costs as it establishes the dangerous principle of allowing the quarrelsome and ignorant a free hand in jeopardizing the liberty of any one so unfortunate as to incur their displeasure, and they themselves escape all responsibility in the matter at issue.

If the court please, we will proceed to examine the allegations in the complaint against the Blue Jay. Again, Your Honor, I ask the dismissal of this case against the Jay on the ground that everything in the complaint, from first to last is clearly dictated by prejudice, based upon hearsay; observations of the blind and the silly drivel of the uninformed, who babble to hear themselves babble.

Gentlemen of the Jury, getting a single kernel of wheat out of an overflowing bushel of chaff, constituting an alleged complaint against my client, let us proceed to examine the so far unproven 
charge that the Jay is a notorious nest robber and devourer of the helpless young of other birds. As this is a case based upon general suspicion rather than a specific act it will turn upon proving the previous good character of the defendant, if that is possible. Now, if His Honor will order me sworn I will take the witness stand on behalf of my client, who has been a close friend of mine for the last fifty years. Fifty years, Gentlemen of the Jury, is a long time and a man and a bird ought to get to know something of each other in such a period, and had I not flattered myself that I know him better than most people I would not have volunteered to act as his attorney in this case. Certainly I will not stand by and see him wronged, for I can say of him, what I cannot say of all my friends, that up to date I never knew him to do anything unworthy of a gentleman and a scholar.

Our acquaintance started on a cold day and it has been getting warmer and warmer ever since. I saw him as the only bit of blue on a gray winter day and he scolded and laughed at me by turns, from a limb of the "tip-top" wood that constituted our first wood-pile and made me ashamed to cry with the cold, after a thirty mile ride, as I carried in my first armful to start the first fire in my father's log-cabin that stood for a home in the wilderness. Always regarding him as a 


\section{I78 What Birds Have Done With Me}

gentleman I of course, never asked him to eat out of my hand, but I have given him something with a stick and possibly my health was better just afterward. To be a little more definite, I have handed him a meal-worm at the end of a split stick as he sat on the edge of his nest after a hard day's work in the support of his family and I'll swear he bowed when he received it, and every man has a right to his opinion so why may I not be allowed to believe that if I could have translated his remark, it would have been: "Your health, old duffer, and may you live long and prosper."

Gentlemen of the Jury, I am not trying to put anything over you when I assure you that this bird, so commonly maligned and slandered, is in very fact, "my friend Yorick, a fellow of infinite jest and most excellent fancy" and it's no exaggeration to say that I had much rather see him on any single day in the three hundred and sixtyfive than a book agent or a tax collector and he would be twice as welcome, if he saw fit to make me a pastoral call, as the professional Soul Saver. Perhaps he may be shockingly worldly, but a fairminded man knowing him in his domestic, social and civic relations to life could scarcely withhold at least a small measure of admiration. The world is full of snivelers who are not willing to 
weep alone but want every one to go into the lawn sprinkler business with them and along comes $\mathrm{Mr}$. Jay and flaunts his sky blue in their faces and says, as clearly as a bird can: "Oh! Patience don't mention it; people have enough of that without making a community service of it so just pack your troubles in your old kit bag and smile, smile, smile."

My friend Yorick should be especially dear to the heart of Ella. Wheeler Wilcox for he laughs whether the world laughs with him or not and however much you persecute him with your guns, traps, poison, he is now and always: "O'er all the ills of life victorious." I do not claim that he is to be compared to a "Yellow prim-rose on the river's brink" so far as a poetic uplift goes, but I do aver that in my heart he has stirred: "Thoughts that do lie too deep for words." Oh! you don't like his shrill unmusical ear-splitting squawk. I do not blame you very much, but I question if I ever heard it just as you have. It's the noise of the children of that neighbor whom you do not like that is especially offensive; the noise of your own children may sound like music. There is a difference. Then we must reckon with individual taste. Don't misunderstand me; I'm not putting my friend Yorick up as a musical prodigy, far from it. As a singer he is in the class 


\section{I80 What Birds Have Done With Me}

with the Pea-cock and they may have attended the same singing school. Nevertheless, I'd rather listen to forty Jays than one Hawaiian Band.

Years and years ago, when I was an officer in the Penitentiary of Wisconsin, there was a Jay there, the prisoner of a prisoner and in spite of his gloomy surroundings he was a gay rollicking fellow, with more pranks and whimsies than a Parrot or a Monkey. It was a matter of frequent comment that he was such a favorite with the inmates of the cell-house where he was kept and it was generally understood that when prisoners hurled curses at him, they were compliments in disguise, for they all recognized that his shrill squawk had power to bring to them, even through barred windows, the great out of doors.

I never listen to a passionate denunciation of the Jay, generally expressed by a string of opprobrious epithets, a few laps longer than the moral law, without being reminded of the quarrel between a couple of negro boys; when one had hurled at the other every obnoxious term he could think of, the one assailed quietly remarked, "All you say I am, you is." You think the Jay a thief and a robber, well he returns your sentiment plus a distrust of you, in all your ways, unequalled by anything in the bird kingdom. Don't be deceived by the fact that he is not wild, that is explained by the further fact that he is not afraid 
of you and though he builds his nest near your home, he never relaxes his belief that you will do him a mischief if you get a chance. Try to feed him and you will see just how much he believes in your benevolence. He will swoop down and snatch some of the offered food, but it is frankly the act of one robber robbing another robber and not the act of a friend receiving a gift from another friend.

It was a proud day in my life when after a thousand failures a Jay allowed me to give him something. I well remember how I smiled all over and asked him to come around and drink tea with me that evening. He excused himself, but we got to be real chums and our relations were cordial if not exactly intimate. What an interesting vagabond he was. My old Collie dog, Lobo, was old and stricken in years and the dinner given him was often beyond his capacity and he would lie down in the sun outside the kitchen door and straightway go to sleep on guard, for which of course, according to military law, he should have been shot at sunrise, but he was not stood up against a wall and so Yorick, not wanting him to go scot free for such a lapse from the obvious line of duty, took the occasion to rob him of the remainder of the badly guarded dinner. After which he would perch himself on a nearby stairway, just out of the sleeper's reach and proceed 
to whistle till the foolish old dog waking out of sleep would charge the robber whose spirit of mischief was beyond question.

None of his bird neighbors either fear or dislike the Jay and his veracity is never questioned. He most fittingly is dressed in blue for he is the real police-man of the bird kingdom and is always on his job. Just let an owl, making a night of it, resolve that he won't go home till the day after and he can't hide himself on the lawn so the Jay will not spy him out and call all the race of birds to mobilize against a common Hun, and Château Thierry, in a small way is reënacted under the leadership of a sure enough American general. Take your gun and dog and start to the woods for a day's hunt and a certain blue-coated guardian of the forests gets there ahead of you and goes slipping through the tree-tops, warning all wood folk of the coming of man, the most destructive of all animals.

Gentlemen of the Jury, I put this up to you to pass upon the probability of a real criminal enjoying the confidence and respect of his neighbors, having a reputation for veracity never questioned and a reputation, among those who know him best, as something of a philanthropist in rendering help to the needy. On the question of nest robbing, I might assure you that I have known a Jay and a Robin to bring up their broods at the same time, in 
the same tree and the tree not a large one at that; but according to the old saying that one blue-bird does not make Spring, so a single instance is far from being conclusive in the establishment of any allegation.

Now if the court please, I will introduce here, marked Exhibit A, a scientific examination of the stomachs of two hundred and ninety-two Jays, killed in the breeding season, in almost every state in the Union, the work being under the direction of the Biological Survey in Washington. The results are certainly astonishing and probably to no one more than the amateurish investigators and hear-say mongers bringing this action. Out of the whole number of investigations made it was found that only five could have been guilty of anything like nest robbing. Three contained fragments of shell; one undoubtedly, that of a smaller bird; another stomach had a fragment of shell that might or might not have been that of a domestic fowl, and the third seemed to be a fragment of the shell of a grouse. Two stomachs contained remains of birds. One the undoubted fragment. of the body of a small bird recently hatched; the other stomach had in it the feet and claws of a fully-mature bird, variety unknown.

Now Gentlemen of the Jury, let us go back and weigh and estimate this evidence of guilt, and I think we will find that it will furnish precious little 
I 84 What Birds Have Done With Me

comfort to the plaintiffs bringing this case. With regard to the shells found in the stomachs, in all fairness the one that resembled the shell of a hen's egg should be excluded as it is a well-known fact that such a fragment is often thrown out from back doors, where Jays come to look for scraps, especially before people are up in the morning. In one of the two remaining cases the shell was thought to be that of a grouse, found late in August, long after their nesting season. No evidence of nest robbing in that find. The third was the shell of a song bird, but in the breeding season all birds drop eggs on the ground every where and it is to be questioned if it had ever been in a nest. With regard to the fragments of birds found in the stomach, one was a part of a nestling, but there is no proof that it was either killed or taken from a nest by my client, for even people who have next to no knowledge of birds or bird life, know that young birds sometimes die in the nest from various causes and the first thing that the mother would be likely to do would be to throw it out of the nest, where anything might pick it up, although no nest robber.

With regard to the last and final examination, it furnishes no proof of wrong-doing upon the part of a Jay, for it is clearly evidence of the wrong-doing of a cat, the fragments clearly being the remains of a cat's supper. Gentlemen of 


\section{Jays and Crows}

the jury, the analysis of this evidence spells acquittal for my client. Only two out of two hundred and ninety-two who could by any stretch of circumstantial evidence have been guilty of nest robbing, as charged. Here we rest our case; simply warning you that anything brought forward by the plaintiffs will surely turn out to be incompetent, irrelevant and immaterial, and not evidence.

Having now established the fact, as I think, that my friend Yorick is true blue, I take up the case of his cousin, the Crow, with confidence and high hopes of securing justice for a worthy citizen.

If the court please, this second defendant in the general indictment found against Jays and Crows, will have to be defended along lines already brought forward in the defence of the Jay, and I herewith demand the discharge of my client on the ground that no State can have jurisdiction in the life, liberty and pursuit of happiness of a bird that is not, so to speak, the citizen of a State but the ward of the Nation. As my motion is refused, Your Honor, we may as well proceed to trial. Again'I wish to be sworn and put upon the stand as the first witness.

Gentlemen of the Jury, is it not an astonishing fact that good citizens who have conscientious scruples against painting the devil blacker than he really is have no scruples, conscientious or other- 


\section{I86 What Birds Have Done With Me}

wise, against painting my client blacker than he is, and even blacker than the devil.

I honestly cannot tell just when and where it was that I met my first Crow; I am, however quite certain that it was not at a conservatory of music and it might have been at the obsequies of man's noble friend, the horse. Perhaps the way he sticks around after what has been done to exterminate him may be traced to this same habit of getting, so to speak, the first chance at the glue pot. Being an undertaker's apprentice, it is fitting that he should wear black and eschew frivolity of all kinds; a sad bird, indeed, if sadness is to be accentuated by a customary suit of solemn black. Strongly social by nature, some think he has a language, and if that is so, per adventure he gossips or talks shop.

Leaving the domain of conjecture and coming into that of fact, it may be averred that no other bird has been the victim of so much prejudice, perjury and piffle. Pre-judgment is the forming of an opinion before you are in possession of the facts in the case and such an opinion once adopted is frequently held with the utmost tenacity when facts are presented calculated to overthrow your pre-judgment. Sentiment, dislike, love, hatred, rarely have a foundation of fact and you can do no more to change them by pelting them with facts than you could drive away a fog by throwing 
stones at it. The Jay and the Crow are hated because they are believed to be bad birds; show them to be good members of the bird kingdom and many people will not change their dislike of them an iota.

$$
\begin{aligned}
& \text { "I do not like you Dr. Fell, } \\
& \text { The reason why I cannot tell, } \\
& \text { This single fact I know full well, } \\
& \text { I do not like you Dr. Fell." }
\end{aligned}
$$

Just as the mind crowds the unknown with foolish superstitions, so we endow what we dislike with every detestable quality that the imagination can conjure up and this is the human quality that has conceived of total depravity as a condition not uncommon. We use the Crow as a unit of measure in estimating conditions of blackness, and as black as a $\mathrm{Crow}$ is superlative. $\mathrm{He}$ is a bird belonging to the realm of uncreated night, mysterious, probably devilish. This belief was clearly in the mind of Edgar Allan Poe, when he wrote of the Raven, the Crow's first cousin: "And his eyes have all the seeming of a demon that is dreaming." Now in spite of all this the Crow is not as black as painted, and there are even white Crows.

What lies have been told about him, by people who never meant to lie, and the lie in combination with printer's ink has made a fine mechanical mixture for the dissemination of falsehood. A 
188 What Birds Have Done With Me

dear, old grandmother, with three grandsons over in France helping make the world safe for Democracy, and a woman who would not intentionally misrepresent, told and it got mixed with printer's ink, too, that she saw a wicked, black Crow steal and carry away a clutch of fifteen hen's eggs. It was not stated just how he carried the eggs, so you are at liberty to make a guess whether it was with claws or in his bill.

Again, a very honorable citizen, an official member in a rural church, stated that he saw, and this got mixed with printer's ink, too, a wicked black Crow-as black as ever Crows can becarry away a whole brood of baby chicks, one by one, in his talons. And taking the public into his confidence, he lapses into a reminiscence of a barn-building that he carried on for a brotherin-law, way back in the early settlement of Wisconsin, and having to walk through a woods to get to his work, carried his gun and without loss of time kept his family table supplied with Grouse. These birds, according to the statement, were so plentiful and tame that he sometimes got a mess on a rainy day shooting from the windows of the barn. At the close of his valuable contribution to natural history, he solemnly avers that since that time the Grouse have been practically exterminated by the nest-robbing Crow, possibly a Crow with talons. 


\section{Jays and Crows}

To my certain knowledge a Grouse had her nest on the ground, in part of an old tree-top blown from a giant white-oak and in that oak a Crow had her nest and the bad nest-robbing Crow never molests the eggs or callow young of her nearby neighbor. And I have a hen-house on the edge of a big woods where Crows have nested for the last quarter of a century, but to the best of my knowledge and belief, no egg or young chicken has ever been disturbed. As a matter of fact, no Crow could possibly carry away a hen's egg, and they have no talons. So far as I know they prefer their game and meat a little high. The Crow being a bird of uncanny intelligence, supernatural cunning, seeing and hearing everything going on in his neighborhood; no nest could be hidden and none would escape if he made a business of robbing them. According to the Scotch verdict, the charge against him is " Not proven."

Now the farmers' charge against him is not as a nest robber, so much as a corn puller; pulling the young corn when it first comes up. It would be folly to allow my client to plead not guilty to this charge, for it happens to be true. In certain localities and under certain conditions, the Crow develops an appetite for the well-soaked, soft and mushy germinating kernel, and damages the coming crop. Some years he pulls no corn, and in some States he is a pest and not in others, and the 
I9o What Birds Have Done With Me

damage he does is insignificant compared to his destruction of the June Beetle, the parent of the frightfully destructive White Grub. The Crow may take a few hills, but the Grub will take the entire field. There is something almost ridiculous in the devices advocated to trap the June Beetle; flickering lights and tubs filled with water and kerosene, the light to attract, the mixture to drown, and the great Agricultural Schools advocating the "Light Water Trap," does not seem to have thought of giving the Crow, the Beetle's natural enemy, a chance. Later on we may be told to go after the June Bug with machine guns, bombing air-planes and gas shells, and at the same time continue the bounty on Crows. Piffe, wretched piffle.

Serious consequences follow tampering with Nature's balance. Men, to preserve the teeming finny tribes that abounded in the four great rivers that empty their waters into Mississippi Sound at Biloxi, went ahead and killed the Alligators that also abounded, and the result was the vast multiplication of the Alligator Gar-fish, upon which the Alligator fed in such numbers that it speedily destroyed most of the game fish.

Hawks, Owls, Jays and Crows have been slaughtered, things useful and beneficial in the scheme of Nature to the great detriment of growing crops for the removal of their natural enemies 
allowed pests and vermin to multiply and the balance of Nature has been disturbed. A lady said to me the other day, half petulantly, "If you seriously defend Jays and Crows I would not be surprised to hear you demand protection for Snakes and Skunks." I made answer, "I am surprised that you have not heard that I have been demanding protection for both, for more than twenty years."

Gentlemen of the Jury, that farmer is only once removed from a fool who demands physical beauty and the ability to either sing or whistle from everyone in his employ. If he does his work and does it well, he should be protected and reasonably remunerated, quite independent of how he strikes our fancy. The public press, the rostrum, the pulpit, and a great commission, and even blank walls, have been shouting to us for months that FOOD WILL WIN THE WAR. The lesson is obvious; everyone was to unite in conserving it, why not allow the bird to keep it from the destruction of swarming myriads of Hun insects and rodents. Hunger is a monster, disregarding every law, it can make a cannibal out of the flower of our highest civilization, and neither Jay nor Crow nor human creature is to be punished for what they are driven to by starvation.

Gentlemen of the Jury, I demand acquittal for the Crow as I did for the Jay; on the ground that 
192 What Birds Have Done With Me

there was no cause for action. And with this anecdote I rest my case. Many years ago, in a country church, a tame Crow flew into the building and, lighting on the sounding board of a half century ago, interrupted the evening revival by croaking out from the gloom that concealed him from all eyes, when the good man was making the opening prayer: "Damn you," and again, "Damn you," and so he kept it up till human nature could not stand it and, seized with superstitious fear, the Reverend man and the entire congregation fled, with the exception of one old woman, who recognized that it was a tame crow talking. And when he kept on with his maledictions after the two were alone, she with some natural ire, shook her finger in the direction of the voice and said, "See here, Billy, you hain't got no occasion to damn me, for I don't belong to this church no how."

Whether I win or lose, I some way feel that $I$ have at least earned the right of exemption from the malediction of a tame Crow, for I do not belong "no how" to that vast company of superstitious, uninformed, avaricious tillers of the soil who seek his life, to take it away. 


\section{CHAPTER XVI}

\section{BIRDS' COURTSHIP AND MARRIAGE}

Some cynic has said that matrimony among upto-date people is a necessary preliminary to alimony. This cannot be true of our bird neighbors, but they have their preliminaries also, and some of them more or less exciting and even weird.

Generally speaking, we know so little of birds that it may seem a good deal like presumption to write of their personal and most intimate relations. Still we know more of the courtship of some birds than that of the soldier and his girl clinging together on the street, and more of their marital woes than we know of the unhappy triangles of the divorce courts. Man-"the roof and crown of things" - a little lower than the angels, stuff and nonsense, is not to be compared, in devotion and constancy, with his bird neighbors. The stones that have been thrown at birds, since time began, had better have been thrown at man if he, in his smug superiority, were capable of taking a rebuke. 
I94 What Birds Have Done With Me

The human race today is something turned out of a melting pot, cannibal and patrician, with all grades between producing mongrel tribes covering the earth. The bird, free to follow its own nature, produces neither hybrids nor mongrels. Think of it, a thousand ducks migrating together, nesting together, and never a cross-bred bird; birds are always and everywhere, true to species. Do you begin to feel the rebuke of it? Is their conduct or man's the most astonishing?

A few years ago I closed the bathing season at Green Lake by accidentally going into the water in a successful effort to get a wild duck out alive that was being frozen into the ice, being unable to fly owing to a broken wing. He was taken home and put in a pen of Pekin ducks, eleven females and one drake, and this drake was accidentally killed by a playful colt, when the flock crawled under the fence into the horse yard. This left Mr. Green-headed Mallard in sole possession of a snug little harem of his own. Talk of peas in a pod, those white ducks looked exactly alike and yet only one appealed to the little stranger from the wild. The courtship is a sealed book, or was it not made into a book as is so common; about the only thing I am certain of is that it was carried on late at night, which may be the only thing certainly human about it.

We first became sure of their marriage, seeing 
them together in the opaline light of an April dawn. To quote from Ella Wheeler Wilcox's "Birth of the Opal" perhaps: "The dying day was their priest." "For this cause," says the old marriage service, "a man shall leave his father and mother, and shall cleave unto his wife, and they shall be one flesh." Now this is as true of ducks as of humans, and as true of Mrs. Hen as of Mr. Drake. In the case in hand, she did the cleaving; leaving her family and following her uncivilized husband to a nearby island, where she performed the duties of wife and missionary to the heathen, at one and the same time.

During the long-drawn-out period of incubation her family were more or less devoted, making frequent calls when they were swimming by, and who knows, aunts and cousins and even sisters may have asked the family's new member to take a little swim with them, but he never did. He surely looked lonesome as he swam back and forth in the lagoon near the nest and I am certain he was; and my six-year-old granddaughter dubbed him Dr. Mally because he did so much quacking. How "Mally" caught the spirit of our civilization, heaven only knows. I am dealing in facts, not psychology, and it is a fact that the very next year he had five white wives and two gray ones, and his name should have been changed to Lot.

The aimless Puckyan is a stream so crooked 


\section{What Birds Have Done With Me}

that it has been told that an explorer seeking its outlet, it never had an inlet, followed its winding course through more S's than are in the name of the State of Mississippi; and tied up his boat and stayed all night at a farmhouse on a bend, and after paddling all the next day, tied up his boat and stayed the next night at the same house, never having gotten out of sight of it. The languid little river, a river that never grew up, meanders somewhere in the "Big Marsh." The owner of the house at the bend, Mr. Wiselander, came back from the Big Marsh one late September afternoon with a high load of hay and a baby Sand-Hill Crane, the longest-legged bird that ever wet its ankles in the deep places of the Puckyan. When he first saw it he got a notion that it wanted to catch a ride and there was no waiting for a second invitation to come along and take pot luck at the farmhouse, not, however, the usual pot luck given birds. This strangely tame creature from the wild was soon at home at the farm and spent its time taking bird's-eye views of terrestrial things. How it spent the winter looking down on the woolly creatures that some way got their noses into a big barn that had been assigned to a star boarder, are matters to be passed over in well-bred silence. Neither have I time to tell of his possession of a prudent mind, like Mrs. John Gilpin, a mind that would not allow the daughter 
of the house to bury perfectly good tulip bulbs, and forced him to resurrect the same and store them away for future use.

Jumping many attractive little hurdles, so to speak, just turn your opera glasses upon Mr. S. Hill Crane and myself as in the soft Spring weather we turn our unequal steps in the direction of the Big Marsh, he, in pursuit of experience and $\mathrm{I}$, in the pursuit of knowledge. We both got what we went for; he got a wife and I, knowledge of what it means to be best man at a high-up wedding. It was both an old and a new campaign, but no listening post was needed; you could not even escape the soft nothings he whispered to the South wind before she paused in her cloud, as though saying to herself, "Why not a little home of my own close to the gushing heart of the Big Marsh?"

Not all lunatics are lovers, but all lovers are lunatics, and the crazy things that fool bird did I am afraid to tell for I am not sure whether I saw things or dreamed them. It's easier to think that I really got what I am about to tell from "Alice in Wonderland" than from the Big Marsh, where my father used to buy standing grass for fifty cents an acre, when I was a boy. A good wife always comes at your call and as she came at his from the first, I knew what kind of a wife she was going to be. He had no claim check upon 
198 What Birds Have Done With Me

her when she first put in an appearance, while she had a stop-over and was just looking around a little. On close inspection the Big Marsh was a trifle flatter than she had supposed, and she preened her left wing and waved her right one as though for immediate flight. It was now or never. Doubtless you are saying he will show her what a swift flyer he is, how fast he can run, how many frogs he can catch in an eight-hour day; perish the thought.

The crazy jumping-jack knows the way to the feminine heart, the battle is not to the strong, nor the race to the swift, any more certainly than is the dance, the last argument of lovers. Ghost of a cotillion of wooden-horses, minuet of a Hippopotamus, five-step waltz of a Giraffe and Kangaroo; S. Hill Crane has you all beaten to a frazzle. However, nothing succeeds like success, and those graceful gyrations of his do the business, and according to the long-established usage of the conventional novel, I should merely add: and they married and lived happily ever afterward, but I want to say that he who went forth in the Spring alone, returned in the Fall with joy, bringing a wife and heir with him.

Life is such a tangled skein, the bitter and sweet co-mingled, before spring the silly sheep had trampled the life out of his wife, and the winter wind slammed a door, breaking the neck of his son. 
Lonely is the Big Marsh today; the few passing Cranes have discarded it as an æro-station, and the call of their old enemy is fading from the subconsciousness of the younger generation of frogs; if heard close at hand I do not believe one would dive to cover. All this occurred more than a quarter of a century ago and Mr. S. Hill Crane has moved to town with the family with which he has lived so long, and spends his last days looking down on chickens and in the Spring, uttering soft nothings to the South wind, that has, also, seemingly abandoned her wireless station on the Big Marsh.

When we went into the wilderness to live in a log house; that house was only a mile from the village of Dartford, but between our house and the little village was Mills' Swamp, and through it the road was made by placing little logs side by side, and then putting brush over the logs and dirt over both. The track was not more than a dozen feet wide and neither side was fenced, but old Mills was going to fence his side and had piles of rails along, once in such a distance, and for years neglected to build a fence. Why should he, when other people only fenced their cultivated land? There was not another house between our house and the east side of the village, and Jerry Norton had no difficulty in making a certain sevenyear-old boy believe that Mills' Swamp had been 
200 What Birds Have Done With Me

set aside for Hell's Kitchen, as soon as they got it drained. I suppose the point he was making was that they never could drain it and they never have up to date.

Those stranger days when Indians were seen daily gliding along the trail that we called a road, and coming out of the marsh with strings of dead pigeons; its visible terrors were enough to raise goose-pimples on a young frontier tenderfoot, but it really was the unseen, lurking hideousness of the swamp under the curtain of night, all manner of unearthly noises in the sky that settled down to taste the bubbling hell broth that was being cooked by a million flickering lights, that froze a fellow's blood.

Dr. Barnes coming along this road to see my brother Ted, who was sick, had left his tired horse at home and was just opposite the fifth rail pile when from the next rail pile, a mighty Mountain Lion sprang into the road with a raucous screech that for an instant silenced every other noise in the wilderness, except the beating of the doctor's heart. The stars were out, but there was no moon and the most obvious things about the attacking beast were its eyes and tail; the tail in constant motion as the big cat lashed its sides and the green eyes emitting sparks of fire. The doctor thought at first that there were about fifty feet between them, but as the night prowler ad- 


\section{Birds' Courtship and Marriage}

vanced, the man with the saddle-bags on his arm, backed away in the direction of the village, having on hand a progressive case whose course could not be checked by the kind of pills he carried. The agitated gentleman was trying to over-awe it by the gleam of his brown eyes into its two points of flame, and perhaps he succeeded to some slight extent, but the close proximity of the village, swarming with dogs, was most likely the reason why a good hunter went to bed without a late supper. The doctor made his professional call later, having exchanged his saddle-bags for a double-barrelled shotgun loaded with buckshot, and brought with him, as further body-guard, Bill Marshall and Charley Cody, each armed with a long rifle, muzzle-loaders.

The township hunt organized and carried on with vigor, saw many traces of this undesired visitor from regions to the north, but the beast eluded all pursuit. But this is another story. They sent me to the doctor's boarding place that he also used as an office, for some medicine for Ted, now nearly well, that would be found waiting my coming. As hero of the Mountain Lion story, the doctor's time had been a good bit broken in on and he had forgotten to put it up. His landlady was sure he would be right back and advised me to wait. I waited and waited, and waited, and it was dark when he got back. 
202 What Birds Have Done With Me

It was really outrageous to have allowed a little fellow to go through that marsh so soon after that unsuccessful Mountain Lion hunt, but there is this to be said, that the big scare made many others, afterward encountered, seem comparatively trifling. It was doubtless a Mountain Lion, but they called it a Panther, and it took up my trail the moment I got out in the night alone. I thought I was giving him a good run for his money, as the saying goes, but he some way outran me and when I got to the fifth pile of rails, he rushed from the sixth pile, his old lurking place, and sprang upon me. Undoubtedly a person may be paralyzed with fear, and I must have been, for I made no attempt to escape. The impact of the creature's body knocked me over, and the creature began licking my face, naturally enough as it was our big dog that had come to meet me. That I did not choke him to death through pure joy, is little short of a miracle, but strangely enough I was more afraid of the sure-enough Panther than I had ever been.

This digression is simply to establish the fact that bird courtship may be of so fascinating a character as to actually overcome the most deadly fear.

A booming noise, unlike anything else on earth, starting at the earth and seemingly going around in a circle, up, up in the sky, and when it had 
vanished, the same thing coming nearer and nearer and dropping in the grass at your feet in the late twilight, or early dawn, when sight and fancy are one and the same thing. Before $I$ was ten years of age $\mathrm{I}$ had followed this gripping mystery all over that swamp with a Panther hidden behind every tree, and a convention of them assembling in every thicket. I just could not give it up if I died for it. A ditch through Mills' Swamp emp. tied into the Puckyan, right opposite "the deep hole," which everyone knew was the very best place to catch chubs for pickerel bait. Freshets from the melting of deep snows in the spring, and occasional heavy rains in summer brought floods of muddy water into the sluggish river and along the south side, under the shadow of venerable elms; a considerable mud bank was formed and this mud bank was, from time to time, perforated by holes as big as a lead pencil, a kind of a Brobdingnagian piece of honey-comb with no suggestion of honey. It was a crazy trestle-board upon which the outline of no theory could be erected.

It was likely early in May or late April, on the eve of a fishing Saturday that I fished the deep hole for chubs with which to catch the king of great Northern Pike out of Green Lake, and if not actually the king, I at least, hoped for the heir-apparent. I think it rained and I did not 


\section{What Birds Have Done With Me}

go fishing the next day, but that chub fishing I have gone back to oftener in memory than any other fishing I ever did, and still rank it as a great event in my life. The mystery that I had pursued so long and so far, suddenly staged itself along the inner edge of the mud-flat, under the outer shadow of great trees and just at the point where twilight and night blended and became one. I thought them snipe and had seen them across the river pursuing each other while I fought mosquitoes and caught bait. I was sole audience, sole press reporter, at a Woodcocks' Gretna Green without knowing how privileged a character I was. It was as novel a kind of "Seven Up" as any that could have been played out for Alice when seeing things in Fairyland. Why seven up? For the very excellent reason that going and coming, there were just that number at one time in the air. What an astounding mode of courtship -an ærial dance. The male bird doing all the dancing; making unearthly booming sounds and spinning around in the air as he climbs invisible stairways till he hears the angels sing, then the return trip, falling at her feet, but quite done up till the next time.

It's not only mysterious, it's inexplicable, but it does the trick and is presumably the surest way to ensnare the affection of Miss Henrietta Woodcock. This is billing and cooing with a long dash 
between each bill and coo. If the little god of love who presides over human courtship and marriage, also, follows the courtship of a Woodcock that may explain why we see him pictured with so few clothes-stripped for a race. An old sailor here in Biloxi when asked if he knew what caused the tide, admitted that he did, and proceeded to explain it: "You know," said he, "when a feller turns over in bed he gets there quite a bit ahead of the covers that come a-rolling and a-swashing along after him, and when the world turns over in the ocean, the waves come a-rolling and a-swashing along some ways behind. You can explain everything if you are careful to study out the reasons." He is not here now and it has always been a matter of regret that I never asked him to elucidate the seeming mystery of the Woodcock's courtship.

Male birds are the greatest lovers in the world, always excepting Wilson's Phalarope. Though he belongs to Mr. Wilson, I greatly suspect him of being secretly opposed to the League of $\mathrm{Na}$ tions, for he is publicly opposed to the holy bonds of matrimony, and is on the wrong side of most things-miserable little no-account snipe. $\mathrm{He}$ is no Lord of creation. Good Lord! his wife has to do all the courting and threaten him with a breach of promise case before she can force him to marry her and he just hates her because she is 


\section{What Birds Have Done With Me}

bigger and stronger and better looking than he is. Could any wife respect such a husband? You know she could not, and I, for one, think she serves him just right when she leaves him to incubate the eggs and rear the family, without help from her. Cutting all domestic matters she devotes herself to civic affairs and is a really respected suffragette. This Miss Nancy, old hen, Bridget, Child's Nurse, he, Phalarope, is the mean little exception to a sex that has made wooing a profession and song and love, synonymous. 


\section{CHAPTER XVII}

\section{A LAST YEAR'S BIRD'S NEST}

This is a proverbial type of emptiness, but Nature abhors a vacuum and emptiness is speedily filled with things visible or invisible. At a first glance, this dilapidated, weather-worn old nest seems as bare as old Mother Hubbard's cupboard, but before you can look twice, a ray from Aladdin's Lamp has gilded and beautified and crowds its emptiness with teeming life.

Lo! we are in the presence of a work of art, not made with hands, and of a model to be seen "through the latticed windows of the grove," when Time was young. Yes, bird-craft is greater than hand-craft, for no human creature, using his hands and mouth alone could equal the wonder of this old nest. This Master-Builder could have never been taught Geometry, but he, nevertheless, never fails to produce a perfect circle in the architecture of a nest whose model is unchanging from age to age and whose craftsmen produce nothing that falls short of perfection.

There is magic here. Aladdin's Lamp is so 


\section{What Birds Have Done With Me}

flooding the old nest with light, unapproachable, that one instinctively begins to fumble for his shoe-laces. We have before us a microcosm, in this shallow cavity, life and melody had their birth, pray God, the life may be unending and the melody as eternal as Time. An empty nest?far from it. Here the miracle of Mother-Love has reflected the visible presence of the Divine Creator of something so holy that in its presence, Art and Song fall down powerless and all speech becomes incoherent mutterings.

I hold the crumbling nest in my hand and try to visualize a form or forms that the depths of space have swallowed up, try to follow the waves of melody that may flow on for twice ten thousand years and my vanished singers, indeed, become "Troubadours and Ballad singers on the streets of Heaven." Much has gone from the nest and much remains. A nest is a type of home and the perfect home, also, has its relation to Past and Future, Life and Gladness, and there is nothing else of greater significance, or more universal attractiveness in this present evil world.

How well I remember my first nest which, so to speak, I held in co-partnership with the parent birds-a pair of Robins. It was located on a corner of a Virginia rail fence, along a lane where I drove cows every day on my father's farm in Wisconsin. I had never seen a nest-it was my 


\section{A Last Year's Bird's Nest}

first year in the country and I am not even sure that I had ever heard of one. When I first saw the Robins flying about with grass and straw in their mouths, I pondered upon it but certainly did not arrive at the right explanation, for, on recovering from having been thrown from the back of an unbroken colt, I resumed my usual duty as a cow-herd, I suddenly saw the nest,-not as high as my head and containing four wonderfully blue eggs-Robin's egg blue-there is no other color just like it. I afterward saw some of the wonders of architecture that man has erected on this earth, I saw diamonds and other precious stones, confronted many of the wonders of Creation, but nothing ever astounded, awed, enthralled me like that first nest with its sky-blue eggs. It has been said that every circus is but a duplication of our first circus and so every other nest among the thousands I have seen has but in a greater or less degree, reflected the wonder of that first nest-a house not made with hands. Wood-peckers building their nests in the very heart of oaks, turning bill and head into chisel and hammer and beating carpenters at their own kind of work, impressed me greatly, but some way it did not seem quite so wonderful as the perfectly round nest made of grass and mud, with its blue eggs under the blue sky. I did not believe the man who first told me of the Bal- 
timore Oriole's nest; a woven bottle, hitched to the tip-top branch of a tall tree, where it was swung by the winds as no boat was ever rocked by the waves. But it was all true, plus the witchery of always finding it complete and never in process of construction. I think I was most shocked and sorry for a little warbler, who, so to speak, always has to carry its nest with it and that nest a Dutch oven. No wonder he walks in the most dignified manner, instead of hopping,- -what else can you expect of an "OvenBird"? The name was given on account of the size and shape of the nest that is built on the ground.

From the Fish-hawk's nest, built year after year, in the same tree, one nest upon another, till you see what looks like a cartload of sticks, down to no nest at all; the eggs deposited on the ground or a flat rock, there are all gradations. So there are all sizes of eggs; from the Ostrich, as big as your head, down to that of the Humming-bird not bigger than a pea. When Jerry Norton, the village liar, told me of birds' eggs bigger than my head, I thought he was lying; when he told me that some bald-headed men had a sun-stroke on a desert and as they lay unconscious, some Ostriches came along and thinking the bald heads their own eggs, sat on them and hatched out ballet-girls, I knew he was. He must have told the 
same story to Francis Wilson and it looks as though he believed it, for he has been telling it off and on ever since.

That birds have unchanging types of nests, built in about the same general locations from year to year, has long been established beyond question. In fact, so generally accepted is the type and the location that at a first glance we might jump to the mistaken conclusion that both are beyond change. There are few rules having an invariable sequence and the general rule of the nesting habits of birds is not an exception. Their rule is changed, some in only a slight degree, others radically. The Swallows have departed most widely in this respect. The Barn-Swallows, with their long row of nests beneath the eaves, have made certainly great departure from the habits of their ancestors, but not greater than the Purple-Martin, from a hole in a tree to his present man-made apartment house.

Perhaps strangest of all is the Swift in the chimney, - the Chimney Swift, braving smoke and fire and gloom profound, not to mention an odor of creosote next to a Hun's gas shell. Great numbers of young must be smothered and burned, but still they persist, doubtless for reasons as mysterious as their place of winter sojourn, which is not known. The Night-Hawk, also, made a stupendous change when it changed from the 
212 What Birds Have Done With Me

bosom of Mother Nature to the flat roof of a city block, where it is not infrequently found nesting.

The Mourning Dove is one of the most inartistic and slovenly of nest builders, often making so shallow and poorly-constructed a nest that a sudden movement from fright will cause her to knock out of the nest one or both of her eggs. What is true of the Mourning Dove was equally true of the Passenger Pigeon and I recall the same Kind of accident to a Pigeon nest that I was watching, many years ago; first, one egg and, a few days afterward, the second were knocked out and broken by the mother bird. That various birds have ideas of adornment and ornamentation is beyond question. I saw a Robin's nest, this last season built in a passage-way beside lattice work and on the side opposite of the lattice work, streamers of heavy cord had been attached to the nest and hung down three and four feet. How else are we to explain the sluffed snake-skin that the Great Fly-Catcher twists around its nest? Bright pieces of yarn and ribbon will take the eye of many a bird as "the weave of a kiltie will take the eye of a lassie," according to Harry Lauder, and whatever else the tartan is, it must be bright to be most pleasing.

I recall a Wren's nest built in a gaudily-painted watering pot, the wrecked plaything of a child, 
both the handle and the spout were missing, but it was clearly the thing the Wren long had sought and it was a possession she was ready to defend with her life if need be.

If we took up the list of odd places in which we have known birds to build nests, like Tennyson's Brook, the number would go on forever. Two we must mention. A Robin, possibly from Boston, built its nest in a hub; one, from Maine, in a boot-leg.

In China, there is an edible bird's nest, that is, edible to the Chinese, and they are welcome to my share; and in the far North many people get both food and drink, figuratively speaking, out of the Eider-ducks' nest, all the expensive Eiderdown of commerce being from the nests of the birds who divest their own bodies to protect their ducklings. Surely nothing else in this world is born into quite so downy a nest. The value of the down has alone kept the duck from the extermination that overtook the Labrador Duck.

The story of birds' nests is a rich lode of natural history which if properly smelted, is easily beaten into leaves as numerous as the leaves of autumn. In other words, the man has not yet been born with the Seer's insight and the Magician's touch to weave again the rare tapestry that Mother Nature's birds have been weaving since the world was fresh and young. The miracle of 
214 What Birds Have Done With Me

it all, the nest and the egg, the egg and the bird, the bird and the flight, the flight and the song, in advance of the fact, if told for truth, it would have taxed the credulity of children and fools. A mass of protoplasm inside a shell, the shell for a few weeks kept warm by the heat of the mother's body, then something alive from within calling for the freedom that life demands, no answer from without, no offer of help, then the cramped, puny creature nerved to stupendous effort by the very urge of existence, batters down its dungeon walls and for days may remain blind and helpless, or in twenty-four hours may be a full partaker of the life of its kind, running or swimming with the speed of adults. That the Ostrich chick should perform this prodigy is difficult of belief: that the unhatched Humming-bird should do likewise is unthinkable; imagination lays down and will not come to our help. In this way, and in this way only, is bird life continued on this planet, where nest robbing is a business, a pastime and a science.

In almost every country on the face of the earth, frequently open and above board and again secret and furtively, birds' eggs are articles of merchandise, the trade under the usual laws of trade, scarcity inflating prices. The rarer the species, the higher the price the eggs of some extinct species selling for hundreds of dollars each 
to collectors. The eggs of our game birds since the settlement of the country, have, to some extent, been used for food, following the customs of savage predecessors. Here is a modern instance of how eggs are eaten in the far North, by the natives. When not quite of age Benjamin Rogers, son of Dr. B. T. Rogers, President of Racine College, Racine, Wisconsin, went to Alaska to install an electric lighting plant for the Episcopal Mission at Point Hope. With five natives he paddled sixty miles to an island to collect Murre's eggs-the Murre incubates a single egg-and they filled their skin boat with such an enormous load that it took thirty-six hours' constant paddling to make the return trip. This incident is only three years old and my intrepid young friend modestly confided the adventure to me on his return. The vast number of eggs collected as a pastime, could they be brought to light, would surprise the average Ornithologist, and astound the public. As a special Game Warden and Conservation Warden, I have examined collections so extensive that no one would expect to find their equal outside of a museum. I recall one in particular, the work of a retired farmer, living in a town of eighteen hundred population, carried on for years, the collection hidden in his barn and kept secret from all his neighbors. Though a close-fisted old fellow, he has bought most of his 
eggs, many secretly from children, and had spent money to indulge this passion as he would not spend money for anything else. A devout church member, when I asked to see his collection he looked me in the face and most emphatically denied having one. The light of a star helped his memory and he took me to his barn, with profuse apologies. The necessity of catching a train prevented me from going through it all, but I had rarely seen the like in any private collection and this the strangest thing of all: he was afraid to own it, would neither sell nor give it away and had no one to leave it to. I imagine that I will not be believed when I assert that fortunes, both in this and other countries, are being spent for birds' eggs and these collections will be inherited by people who in our better civilization, already knocking at the door, will be ashamed to have it known that among their ancestors were nest robbers and they will secretly destroy a gruesome and worthless inheritance.

"The Oölogist" is the name of a little magazine having Science pilloried on its title page, the little mother of yellow journalism, for it is published in the interest of the birds' egg collector, the scientific birds' egg collector, if you please. Behold the noble ambition of "The Oölogist" to promote the distribution of birds' eggs so that every museum and school shall have a collection, 


\section{A Last Year's Bird's Nest}

the larger the better, that the sum of human knowledge may thus be increased. Granted that the object is primarily scientific, I challenge the right of the egg collector to make persistent inroads upon our vanishing wild life, for we are not to lose sight of the fact that the egg of the rare bird is sought above all others. For a fact, collections of eggs and stuffed birds are of small value to the student of Ornithology and worthless to everyone else. The wise teacher of such studies says with the poet Bryant: "Go forth under the open sky and list to Nature's teaching," and the soul of the teacher who would send a student to a city to study a musty, moth-eaten collection of either birds or eggs, must be already dead within him.

To me, an empty nest, a last year's bird's nest, if you please, is still wonderful-as wonderful as the life for which it stands. I have seen some of the great collections of eggs in this country with only weariness and disgust and I have found a half shell on my lawn and found in it a message so wonderful that when I append it here and attempt once more to tell its story, I have the same feeling that I had then, that the story of the half shell is not half told.

To call one half of a blue shell an "Azurite" would be a stilted and fanciful way of speaking of a fragment of a Robin's egg found in the green 


\section{I 8 What Birds Have Done With Me}

grass on the lawn, where the never-ending miracle of incubation had taken place in the tree above. Nevertheless, the one who found it felt that all words were inadequate to express something of wonder and awe in his inner consciousness aroused by the not at all uncommon find.

Beautiful and fragile as the fragment was, it had played its part and was now a worthless thing to be cast aside, but the blue still suggested the sky and the creature that had come out of it, as belonging to another world-out of the blue, into the blue, a relationship between the near and remote.

Surely there is no other day, but a June day, that comes in emerald robes and golden sandals across the far horizon with kisses, and more kisses, for all that are glad and rejoice in the great gift of life. On such a morning a world-weary man came hurrying across the lawn where his "Super Six" awaited him on the drive. As he drew near, instinctively, the owner of the fragment of blue shell closed his hand, as though it would not be kind to show a glimpse of Heaven to a poor wretch who was carrying about with him his own Hell.

The unhappy man's story is scarcely more uncommon than the fragment of shell. Here it is in brief. From his childhood, the poor worldling had been shut out from joy and gladness of the 


\section{A Last Year's Bird's Nest}

wonder world about us. From a tenement, where foreigners were herded like cattle, he had climbed to the ownership of a big factory, an ill-smelling factory, from which dollars came in a stream and this stream had been augmented by war profits till it was a torrent submerging all the landmarks and carrying him out on a lonesome ocean, where there were nothing but dollars and where dollars would no longer buy a thing-all quite valueless. He was in the last stages of a new disease, that doctors could do worse than call Millionitis.

When the wretched, sleepless, wandering Crœsus had eliminated himself from the landscape, the owner of the half shell shyly opened his hand and the first glance convinced him that the fairies had been doing things, while he had been only talking, for the blue had collected all the other rich coloring of a world of beauty. His eyes were suddenly ravished with the light of dawns, sunsets, waterfalls, rainbows, and looking to see that he was not observed, he held the fragment of shell to his ear, and as the sea shell sings of the ocean, his being was suddenly flooded with the bird song of the universe, a feathered "choir invisible."

Time, like everything else in these days, is to be Hooverized and as a matter of fact, the man with the half shell had only stopped his lawn mower long enough to dip up a little of the dewy 
220 What Birds Have Done With Me

freshness of the June morning in the tiny blue cup in his hand. He knew very well that it would be quite impossible to get enough for a bath, but it would take no time to get enough to refresh the lips of the inner man of the heart. 


\section{CHAPTER XVIII}

\section{A SAINT BARTHOLOMEW OF BIRDS}

A massacre is indiscriminate slaughter with unnecessary cruelty, but as it is practically never necessary, it is always cruel and outrageous. Hands red with innocent blood make indelible stains, and that people or nation indulging in blood lust is still in the swaddling clothes of a development just commencing. Massacre is a parent stem upon which mob violence is born in the shape of a gnarled and unripe fruit. Mob violence is an emotion often widely divorced from all sober, serious thought, in fact, it is incapable of thought, as thought would destroy the unreasoning act. The world is just learning the possibilities of unleashed passion with ignorance as a dynamo running wild.

In Longfellow's "Tales of a Wayside Inn" is a poem entitled, "The Birds of Killingworth," and in that poem occur the words that serve as the caption of this chapter. The whole thing described with prophetic vision a Saint Bartholomew of Birds, restricted to a circumscribed area, which 
later on became general, universal. Longfellow is really the pioneer writer on the economic value of bird life, their value in protecting growing things was seemingly as well known to the poetnaturalist as to any scientist who has followed him, examining stomachs and counting noxious insects found therein. In his vision he saw a mighty army of victorious worms, slimy, hideous, crawling everywhere, with nothing left to check their onward march, now that the birds had all been killed.

The birds were massacred by the very farmers whom they protected, for the reason that they were robbers of the harvest. It's the same class of men today who are doing nothing to save what is left of our bird neighbors, an allied army of bird soldiers fighting the onrush of wave after wave of insect life that will, if not checked, sweep the earth. When the men who had massacred the birds saw the ruinous nature of the thing they had done, they sent to other provinces and brought back those forms of life of which their fields and forests had been bereft and restored what was lost. A thing impossible when the countries of the earth have all exterminated their birds. The present bird massacre means bird extermination, final, eternal.

While it may be true that we only know of the absolute extermination of a dozen to twenty 


\section{A Saint Bartholomere of Birds}

species, a vast number of species are close to extermination. I, myself, have seen the awful decimation in the lost half century. I recall photographs of the aquatic life of the Saint John's River, Florida, taken forty years ago. I confess it seemed to be fairly crowded with a prodigal wealth of bird life, the like of which I had never even dreamed of, or waking, thought possible. When I saw the river for the first time, a little over a dozen years ago, the almost complete absence of all life was more appalling than the teeming life that I still had in my mind's eye. Thousands were no longer represented by tens. From Jacksonville to Sanford, some two hundred miles, with the exception of blackbirds, I did not see altogether, fifty birds in the aggregate. With a good pair of glasses I watched from the upper deck, the dawn come over the lonely floods of water and for a long time nothing moved upon the face of the waters, and then far away some fugitive remnants of the life that had been and was gone. Yes! Longfellow was a prophet, had seen a vision and told the story, not only of the Saint John's River, but of the whole world in two lines. Did I recall them or were they actually spoken into my ear, so vivid and astonishing they seemed :

"The wild wind went moaning everywhere,

Lamenting the dead children of the air." 
224 What Birds Have Done With Me

I, myself, witnessed the exodus of the Passenger Pigeon; saw the flocks grow less and less, and finally vanish. The repulsive story of that great massacre is too well known to need repetition, and it is only worth while from its possible power to point a moral and adorn a tale. People said then, are saying now, you can't kill a species, they were not killed, they died of disease. The graceful Pigeon and the lordly. Bison, strangely enough, were both afflicted with the same disease-humanitis, caused by the sting of a tiny microbe, the very deadliest on the earth. Within the historic period no race of creatures has become extinct without the aid of man, microbe, or "Lord High Executioner," call him what you will.

Massacre is defined as indiscriminate slaughter, but not so of necessity as it may be very discriminating, so things killed in great numbers by starvation or the sly, prowling decimation of secret enemies, are scarcely slaughtered with violence. I wish to define my poetic sentence, at the head of this chapter as extensive, unnecessary killing with or without discrimination or violence. The destruction of a bird's natural environment with nothing to take its place, may look toward the final destruction of that species as certainly as work done with gun or club. The wholesale destruction of great forests and the draining and cultivation of great areas of low land has meant 


\section{A Saint Bartholomew of Birds}

death to certain species. Civilization does not mean bird extermination and certain harmless beneficial birds would flourish where the soil is largely cultivated, were they not harmed by enemies having nothing to do with a changed environment. Were districts reforested and tangles left along hedge-rows for hiding and nesting places, there need be slight loss of bird life. To this, if food was added in inclement weather in winter, these wild neighbors would become more than half domesticated in many instances.

Among causes resulting in extensive destruction of bird life, I would put first of all, the all but universal armament of young boys with air-guns. Military training of boys makes the efficient army; the air-guns develop and make efficient, the adult hunter, killer, slaughterer. Three-yearolds go to camp in the space under the sittingroom table and there is enough witchery in the air-gun to connect their present camp with one in the wilderness, where this plaything shall be transformed into a real gun, and they, into mighty hunters. If you would question the "true sportsman," asking him when he became interested in hunting and if he answered truthfully, ninety-five per cent. would say, "Why, always, ever since I had my first air-gun."

Children utterly ignorant of the commonest 


\section{What Birds Have Done With Me}

birds are sent out with the injunction to kill only English sparrows, if they belong to families in that small minority who happen to know something of the value of bird life, otherwise without any limitation as to what they shall kill, but the inability of the juvenile hunter to tell birds apart results in both cases, in the slaughter of all varieties of sparrows and other small brown birds. A couple of fairly-grown boys here in Biloxi shot seventy-one Cedar-Waxwings, calling them, and I think, honestly believing them, to be "a kind of English Sparrow." Thus many a bird has suffered death by proxy and the killing of one variety leads to the indiscriminate killing of all. Boys, air-guns, Sparrows, - all taken together, may seem of small significance and be only remotely related to bird annihilation, but are certainly antecedent causes. Why mob law for English Sparrows?

In the treatment of this small stranger within our gates we have made an exception, if there was ever any reason for charging us with being Anglo-maniacs; the rule has been open hatred and in the neutrality of those professing it was the usual element of prejudice.

Even State Audubon Societies have been made to seemingly endorse the "sparrow-trap" man and publications, carried on in the interest of bird protection, have advertised a scheme to help 
destroy a whole family of friendly little birds, and the members of civic organizations have often turned themselves into cunning Borgias with the same end in view.

These visitors from over the sea have insisted on living in close proximity to their worst enemy, man, who has betrayed their trust and mobbed, killed, and persecuted them in every conceivable way, and done it in the name of bird protection. The cry has been: "They drive away our wild birds, rob their nests and even kill them." As a matter of fact, there isn't a word of truth in the charge; man, the killer, has the monopoly in that kind of sorry persecution and destruction. After years of this treatment we are just beginning to find out that the English Sparrow is a real help in the struggle for existence and a beneficial bird in our war with noxious insects. The Federal Department of Agriculture is certainly in error when it proposes to incite Boy Scouts and school children in carrying out mob law against a bird really deserving protection. That the public press, somewhat generally, is protesting against this proposed "St. Bartholomew Massacre" of English Sparrows is most timely and may prevent a modern enactment of Longfellow's "Birds of Killingworth," which, if pulled off would be apt to cause "the spirits of the wise to sit in the clouds and mock us." It now looks as though the Eng- 


\section{What Birds Have Done With Me}

lish Sparrow might soon be allowed to take out his first papers.

No one thing would result in so great a saving of bird life as the passage of a law making the air-gun, like "a bird-cannon," a thing contraband, as detrimental, enormously destructive to forms of life, essential to the very continuance of vegetation on the planet. The Federal Agricultural Department, having the enforcement of the Migratory Bird Law should stop the manufactory and sale of the harmless little air-gun, that like a dumb watch a little later on is sure to be changed to a live one. With no air-gun in the hands of the callow youngster, and no license to hunt till a boy has attained legal manhood, a mob is transformed into a drilled army. Can anything be more unwise than to make sportsmen out of the rising generation, and then hire Wardens to stay the killing of useful birds? Certain evils are best controlled as near as possible to the fountain head.

The church and the school and the home must be made active in the cultivation of a superhuman soul against killing. Why prattle about the cultivation of human education? Education is always on the side of the killer; it's a wilderness where flesh-pots are the things most to be desired. "Thou shalt not kill" must some way be put into the super-soul of mankind, a new religion in which 
the non-shedding of blood shall be the central tenant. When such a super-consciousness becomes universal a stain shall be removed from church, and the school and from all homes.

Back of the Plume Pirates, shall we say higher up, are the women of our best society and back of them hideous, merciless Dame Fashion. Is there no flash of sympathy common to all mothers? Is it really possible that a human mother knowing that her borrowed plumes are secured at the cost of death to other mothers, dumb mothers, and the slow starvation of nestlings, can still want to wear trophies of a savagery that would shock savages?

Men are not a whit behind the mothers of men in showing themselves merciless, though in their own cases they themselves are the killers, and back of the killing of big game you have but to scrutinize the so-called prowess to discover in it a vanity akin to that of the plume wearer. The great Arctic explorer, Stefansson, puts this thing in its true light: "With me, the matter of big game hunting is another case of swords sticking to hands that seek the plough. I am afraid that I am not a true sportsman. It is impossible for me to get enjoyment out of killing and if I did; I should get a job in the Chicago stock-yards rather than follow poor frightened wild things around with a rifle." 


\section{What Birds Have Done With Me}

them and they protest against the general massacre of the past.

Close upon the heels of worry among sportsmen over the disappearance of the wild pigeon and the early extinction of the prairie chicken, comes prediction of the end of the mallard duck. An Eastern writer observes:

"Formerly mallards existed in abundance, hard to realize at the present time. Until after the war ( I 86I-I 865) the ponds of middle South Carolina supported millions of them each winter. The noise of their flight sometimes deafened one. They were killed by the wagonload. At Big Lake, Arkansas, in the winter of I893-I894, a single pot hunter sold 8000 mallards, and 120,000 were sent to market. In Calcasieu parish, Louisiana, last winter 250,000 mallards were killed.' Hundreds of tons were killed at Lake Malheur, Oregon, for their feathers. In Canada and along the many lakes up to Hudson Bay, duck eggs were sold by the million, their contents to be used in glue factories and for the refining of sugar."

The Superior Telegram, deploring the ruthless treatment of the mallard, contrasts him with the wild pigeon to the latter's disadvantage. The bird, it says, was a good riddance, though toothsome when young and fat. The farming industry could not afford to maintain him, because he was a vegetarian, and never harmed an insect. The 
of all animals and the most terrible scourge to bird life-the vanishing wild life-of America. "True sportsmen," "pot hunters," "the negro with the \$3 gun" all together do not begin to kill as many birds as dear, innocent Tabby. Somewhere around $300,000,000$ annually is supposed to be a fair estimate of puss's destruction of game and insectivorous birds.

It has been well said that the cat fears no law and knows no master; you cannot train his claws not to rend, nor his teeth not to tear. It goes without saying that a creature that has taken possession of the home is bound to be protected by the affection of the whole household and much in the way of education will be required to dislodge it. The cat menace to bird life is ten times as great in the South as in the North, for there, the animals breed to starvation lines and the milder climate seems favorable to Tabby's attaining length of days; her nine lives being increased to at least eighteen.

Sportsmen are only comparatively recently facing the killing off of whole species and the best informed among their number, are appalled by facts that no longer can be ignored. They quite generally admit the Massacre of the Passenger Pigeon, but the latest palliation is the statement that it was a good thing for the farmer. The threatened excinction of Ducks comes home to 
them and they protest against the general massacre of the past.

Close upon the heels of worry among sportsmen over the disappearance of the wild pigeon and the early extinction of the prairie chicken, comes prediction of the end of the mallard duck. An Eastern writer observes:

"Formerly mallards existed in abundance, hard to realize at the present time. Until after the war (I86I-I 865) the ponds of middle South Carolina supported millions of them each winter. The noise of their flight sometimes deafened one. They were killed by the wagonload. At Big Lake, Arkansas, in the winter of I893-1894, a single pot hunter sold 8000 mallards, and 120,000 were sent to market. In Calcasieu parish, Louisiana, last winter 250,000 mallards were killed. Hundreds of tons were killed at Lake Malheur, Oregon, for their feathers. In Canada and along the many lakes up to Hudson Bay, duck eggs were sold by the million, their contents to be used in glue factories and for the refining of sugar."

The Superior Telegram, deploring the ruthless treatment of the mallard, contrasts him with the wild pigeon to the latter's disadvantage. The bird, it says, was a good riddance, though toothsome when young and fat. The farming industry could not afford to maintain him, because he was a vegetarian, and never harmed an insect. The 
mallard, on the other hand, robs nobody. "He lives on the cresses and celeries of the waters, and his flesh is superior to that of his canvasback or redhead cousin. Every state ought to take measures to conserve him, else soon we shall know him no more." What is needed in addition to game laws is public sentiment backed by public spirit that will condemn their non-observance. Without enlightened civic consciousness on the subject of protecting the wild birds, their numbers will rapidly decrease, and beyond question a time will come when the multiplication of insect pests will avenge the slaughter of the feathered races.

Most of the hunting on our Lake, is at the Head, or down at the inlet; both localities having a more or less variety of attractive duck food. At the head the ducks cross from their feeding ground on a near-by marshy lake to the protection of the open water of our lake and were frequently slaughtered in great numbers, night and morning, on the portage between the lakes. If there are Ducks anywhere you can safely count on finding a goodly number at the inlet. When the country was first settled Adolph Buzze not infrequently used to bring a "Dugout" full from the inlet, the result of a few hours' shooting. Adolph was utterly without education, as we understand the meaning of the word, though he actually understood more than the average man, the mystery of 
234 What Birds Have Done With Me

the teeming life in the world about him. Though he may often have wandered and lost his way, every trail he followed led him back to God. Simple minded, good hearted, he hunted and trapped as he chopped wood to support his family. He was a "pot hunter," an epithet of loathing and contempt to every "true sportsman," and it is at men of this class that all of our protective game laws are aimed.

The other day a very different style of a man hunted at the inlet. Everything about him was strictly up-to-date, or rather of the I9I9 model. He was the antipode of Adolph, the "pot hunter," he killed for sport, as every true sportsman does. In the twilight of a November day he came into his store with a single trophy, a solitary Mallard, the only living thing that he had seen to shoot at, down at the inlet. He gave an animated description of his kill: "I thought I was going to be 'skunked' when I saw the vagabond in the rushes near shore. He let me come so close that a first I thought he must have a broken wing and could not fly, but just as Billy was going to give him one with the paddle he got up like a flash and I naturally blew that green head of his into the middle of next week." There were not wanting those who laughed and called him lucky in letting nothing get away, and none had any appreciation of the fact that it was a wounded or a sick bird that 
had furnished the animated target for one who only shot according to law in the "Open Season."

A leading business man, and an exceptionally fine fellow, who has hunted all his life, said only yesterday: "I have only recently learned that I can get my necessary exercise out of doors at Golf and am no longer lending a hand in helping destroy our vanishing wild life."

When Theodore Roosevelt was collecting material for his bloody "African Game Trails," his friend and admirer, John Burroughs, said of his passion to kill things: "Later on he'll slough this off."

Is it too much to hope that America, the most progressive and civilized country on the face of the earth, will: "Later on slough off" an "Open Season"?

In a general way it is better to look ahead than to look backward, but progress must be measured by the backward look. Everything is comparative and conditions actually bad, showing betterment are not without hope. It is the wide view that often makes Giant Despair, at the mouth of his cave, look like a single plant louse on the thorny stem of Time.

Our Government needs ammunition to fight the great battle for world-wide Democracy, but the "true sportsman" needs his recreation and we 
236 What Birds Have Done With Me

hear nothing of any restriction on the amount of fixed ammunition to be poured into our vanishing wild life, during the coming "open season." The slaughter of our bird neighbors for sport is a shameful reversion to savage ancestors-I beg pardon of these same ancestors-they were savages but not guilty of that civilized, smug, bloodthirstiness. However great the discouragements of our immediate surroundings, the wide look shows real progress in bird protection. If straws show in what direction the wind blows, the tiny fact that Metropolitan Newspapers are devoting space to bird lore indicates a better future for our birds. May we not go farther and see the approach of Halcyon days in that future when we find reference in a department of "Woods and Waters," to the kingfisher as a brother fisherman?

Oh! soul of mine remember,

There is really naught to fear,

The days are growing brighter,

Each day throughout the year. 


\section{CHAPTER XIX}

\section{SOME INVISIBLE DEFENDERS}

In one of our recent magazines there were seven articles pertaining to the world war, and one, beautifully illustrated, giving some account of another army, rarely noticed by the average person, whose annual campaign against hordes of noxious insects saves every forest in America. This is no insignificant Council of Defence, working for the general good, unhonored and unsung.

Igdrasil, according to Norse mythology, is the ash tree of existence, and all life is represented by this fabulous tree. The winds among its branches are both shouting and whispering the messages of Igdrasil. The forests are its children and lovingly, devotedly, the birds watch and protect these children, scattered so widely over the face of the earth. All flesh is grass, and grass, protected by the bird soldier, stands for food and nourishment, but the tree has its direct relationships, vast and tender, with home, and home in very fact is the substance of things hoped for. The singing army going through the 


\section{What Birds Have Done With Me}

tree-tops is in reality providing you with a rooftree and a back-log, and this Dr. Henshaw, in the "National Geographic Magazine," the one referred to, calls "A Supreme Service." Think of it; an aviation service, raining only blessings upon the earth.

There is not a tree, symbol of strength and beauty and receiving station for messages from the unseen, that did not have hundreds of insect enemies waiting for it when it came into existence, and without the immediate protection of the birds would have been quickly destroyed, and on the other hand, there is not a giant among all the trees of the forest who would long exist without its Guardian Angel, the bird soldier. The only real fairy stories are the ones that are actually taking place around us all the time, but for which we have no eyes. Solomon in all his glory was not apparelled like many of our birds, and their service belongs to a vaster temple than he ever dreamed of - a temple not made with hands, in which music and service are one and inseparable.

Now that the war is over and the professional tree slaughter is organizing to meet an unprecedented demand for lumber of all kinds, the $\mathrm{Na}$ tion's sylvan treasury will be ruthlessly exploited as never before. It almost seems as though both the tree and the bird soldier are doomed, but the apprehension must give place to greater determi- 
nation to conserve both. The poor narrow-minded lumberman, who sees in a tree only possible lumber must be made to dip into the future and conserve a natural resource for his children and his children's children, protecting and renewing rather than destroying. God save the world from the greed of ignorant little men.

Arrogance and ignorance shroud the morning and the evening of existence of the dyed-in-thewool money grubber, who would sell his Lord for fifteen pieces of silver if he could not get thirty. To them, outside of a sordid commercialism, there is nothing; and were beauty and song exposed on the block, among them all there would not be found a single bidder. People who know all can't be told a single thing.

That we are the people and wisdom will die with us, is probably the conviction of most races of human beings. Any idea of kinship with other forms of life is not to be tolerated; we are the proud possessors of a god-like reason, the brute creation of a blind instinct far removed from man's lofty endowment. Such a belief makes easier the universally accepted notion of a divinely given dominion over the beasts of the fields and the fowls of the air and all that passeth through the depths of the sea. Careful investigation goes to show that there is not such a mighty chasm between reason and instinct as has been commonly 


\section{What Birds Have Done With Me}

supposed to separate us from our little brothers of the field and forest. The word instinct is a blanket term covering a world of ignorance. When a toothless old man soaks his crust in his coffee, the act is prompted by reason; when a duck, that has only rudimentary salivary glands carries a hard crust some little distance to soak it in water, it acts from instinct. A man through local attachment prompted by reason, may travel across a continent to get back to the place of his birth; but a wild duck, hatched in an incubator, may have the same kind of local attachment, prompting it to leave a body of water, its native element, and cross a busy street that it might again enjoy a familiar environment in close contact with human creatures, the barrier of fear having been broken down. Instinct is a great matter for it enabled the wild ducks, spoken of above, to find their way back over a road that they had never seen, over which a man with all his reason might have wandered and lost his way. It is said of man that "Joy and grief and hope and fear alternate triumph in his breast," as though these were the distinguishing qualities of the great gift of reason, but as a matter of fact, dumb creatures, with only instinct for a guide, are not strangers to like emotions. True religion and undefiled is in a recognition of the inestimable value of life, that the highest and lowest hold in common, something 
to be guarded with the greatest care and never recklessly sacrificed. Love and pity are two angels guarding a sacred flame that once extinguished may not be rekindled-Love's Red Cross protecting all life. "He who in his own soul perceives the supreme soul in all beings, and acquires equanimity toward them all, attains the highest state of bliss."

According to high authority, civilization means "to reclaim from a savage state; instruct in the arts and refinements of civilized life." Thus we are taught to regard civilization and not savagery as the adornments of a condition of splendid progress. Facts are stubborn things and lend no countenance to such very superficial conclusions. As a matter of fact, the centuries grow weary over the slowness of the thing we call civilization as it creeps in petty pace from age to age. Man has spent Aeons in getting on his hind feet, and it seems as though more Aeons will have to drift down the abyss of time before he is really reclaimed from his innate savagery. To civilize is a process; civilization a dream. The arts flourish and refinement dies.

The soul of refinement is consideration for everything that lives. A universal sense of compassion for every form of being that in common with ourselves, fears and would escape death. Across the beautiful Lawson Road, between the 
242 What Birds Have Done With Me

Maplewood and the village of Green Lake, I recently found the bloody body of a mother Coot done to death by some fine gentleman, to whom the creature was but an animated target. He gave no thought of a possible callow brood in a nest that stood for skill and mother love, where waters dream and green flags tell their story to the passing breeze. Peradventure his friends congratulated him on his skill as a mighty hunter; no stain of blood, in the estimation of people of the highest refinement, follows such a petty murder.

Here is the whole thing in a nutshell. Humane education is preparedness for Civilization.

There is a story that after all their defeats when the victorious army of crusaders marched into the Holy City, all comrades who had been killed in battle, and from disease had fallen out by the way, joined the army once more to take part in the final triumph. It is not only a pretty story but is symbolical of the way victories are won to-day; thus are all battles fought by the living and the dead, the visible and the invisible. In the late war in Europe, take our part in it; Grant and Sherman, Lee and Stonewall Jackson were Pershing's Aids, and Washington and Lincoln stand close to Woodrow Wilson. Woe to that nation or that cause that has no invisible defenders. Visible orators are as children playing in the market place compared to the deathless eloquence 
of those whom we call dead. What matter if the body lies mouldering in the grave so long as the soul goes marching on? The death of Audubon in no way interfered with his work as poet-naturalist - a real John the Baptist in the wilderness preparing the way for all naturalists who could but follow after him along the trail he blazed. Among the living of to-day there is not to be found among bird-students another whose work and influence is to be compared in virile force and power of inspiration with the first Commander-in-Chief of the present army of bird-lovers. William Dutcher, voiceless, speechless for nearly ten years, through the influence of the Audubon Society, never spoke more eloquently in all his useful, beautiful life than to-day. Audubon and Dutcher rank high as two mighty invisible defenders of the bird kingdom and those on the firing line had as well pull down their flag, were it not for them and all other invisible defenders of our vanishing wild life.

If bird-lovers were without the spiritual insight that sees in death no intimation of the lessening of a man's ability to still further his own work, the passing of Theodore Roosevelt would be a cause for putting on crêpe, and hearing in bird-song a vast, sad requiem. As President, he established the principle of government bird-reservations, and created thirty-eight of these national 
244 What Birds Have Done With Me

wild-life sanctuaries. He was a man of the outof-doors, a hunter and a bird-lover. It was said of him that "he shot lions with a rifle and birds with a field glass. The second sport he loved better than the first." How much of a real birdlover he was is just becoming known and the world is going to remember him not on account of the lions, or other wild animals he killed and thus preserved, but for the efforts he put forth to make bird protection respectable and popular. The statesman and the writer will now be merged into the invisible defender of the invisible defenders of forest and field and all growing things. "Mourny," "Moses," "Mr. Esau" and "Canada" have long been dead, but death, only made them, through me, invisible defenders of things very much alive. The hard bitter materialism so dominant in life to-day has to be reckoned with and we have to learn the lesson of a higher, finer civilization that takes cognizance of the invisible and spiritual that moves the obvious and material. I, for one, love to think of every hard dollar that Mrs. Russell Sage gave to establish a Birdrefuge in the South, for instance, as being transmuted into tender spiritual impulses for better things that invisibly will flow on and on so long as Hope shall prompt Love to conquer human selfishness. 
Some Invisible Defenders

The vision of to-day is the reality of to-morrow and on the reality of many to-morrows, faith will stand to catch the visions of all the coming years. 


\section{CHAPTER XX}

\section{GETTING ACQUAINTED}

In whatever direction we turn, we are confronted with certain visible or invisible barriers that have to be surmounted before any progress can be made. Indeed we are strangers and pilgrims here and will so remain unless we become acquainted with our environment and make friends with other forms of life. In the oldest Poem in the language is this imperative command: "Acquaint now thyself with $\mathrm{Him}$ and be at peace; thereby good shall come unto thee." The thought is self-evident. Immediate acquaintance, immediate peace, and both followed by unqualified good. Taking the old commandment to pieces, in another way it may be justly inferred that acquaintance has been procrastinated and there has been no realization that there is a benediction of peace following knowledge. The ancients located truth at the bottom of a well and we are just learning that good flows only in certain fixed channels, knowledge finds the channels.

Knowledge is that quality that enables us to 
recognize what is best. Knowledge is the Dragoman among ancient Pyramids, and the interpreter of whispering winds and the song of the open road. Yesterday, its garden of memory, to-day, its workshop, to-morrow, its mount of visions. The police dog that made the trip from San Diego to New York and return, with Major Albert Smith through the air, learned precious little of the country over which he passed. And so it is with us who make the journey of the years and fail to acquaint ourselves with our environment. I suppose the person who travels far and learns nothing, might as well have remained at home and the one who goes through life without learning anything might just as well have never been born. All education is just getting acquainted, finding out things about things that actually exist. A real teacher is a way shower and has nothing to do with the fellow who pretends to be able to sell you a big chunk of knowledge that you can carry home with you, to be wrapped up in a sheep-skin, the sheep-skin to be used to burnish the family escutcheon.

Erudition would lose most of its strut and fanlike tail feathers if people only knew that back of its fuss and feathers, it simply stands for getting acquainted.

I have looked out of a car window and counted as we rolled by, two hundred and fifty telegraph 


\section{What Birds Have Done With Me}

poles. I knew them as telegraph poles, they all looked alike, there was no question of the correctness of my identification of them, but there was a lot of facts concerning them of which I knew nothing. For many years I was the owner of two hundred and fifty sheep. I knew that they were sheep and looked much alike and there was no question of the correctness of my identification of the kind of animal that I called a sheep. However, my knowledge did not stop with a few facts, as it did in the case of the telegraph poles, for all my life $I$ had a close and intimate acquaintance with sheep, beginning with a single individual when I was a lad. I came to know this individual so well that when more were added and I became the owner of a little flock, each remained an individual, and when, much later in life, I owned the big flock, each had its individuality as much as two hundred horses I have owned and a thousand head of cattle.

I knew my horses and cattle by name, and the faces and voices and personality of every sheep in my flock. Just as soon as you come to know things as individuals, they cease to look alike. I was making an address not so long ago to an audience of tourists, most of whom were well past middle life and few of whom I knew personally, and I remember of having thought that among them was a general resemblance great- 
er than among the last flock of sheep which I sold twenty years ago and some of whose faces I still remember. Those I remember best had names and nick names; their faces are unforgettable. Beginning with the first colt I owned, when I was fourteen years of age, I can give not only his name and color, but his minute history-his personality-and that is equally true of at least a hundred and ninety successors to skittish, panicky Cruser.

Now I suppose that it would be possible to find at the stock yards in Chicago, individuals who have bought and sold millions of sheep, who have utterly failed to learn as much of the animal as an animal from their millions, as I learned from my individual cosset lamb.

I know a man who, in the last forty years, has approximately prepared and mounted the skins of ten thousand birds, but, while thus in close contact with birds, so far as really learning anything of the real life of the creature he handled, its possibilities and limitations, its good and evil, its individuality and personality; he might as well have spent his time sawing wood. Indeed, I think that the more a man knows of the inside of a bird, the less he knows about the outside; the more he knows of a bird scientifically, the less he is apt to know about the creature's æsthetic, spiritual, companionable worth. 
"To the making of books there is no end," said the wise man, before the invention of the art of printing, and now, when they are being scattered broad-cast like the leaves of Autumn, I feel that a man should have some pretty valid excuse for presuming to add another to an already discouraging number. Now that my little craft is on the ways preparatory to launching, I feel that I must make this matter clear and give my excuse for another bird book. It seems to me, that so far, every writer on the subject has been possessed to tell what he has done with birds, and I approach the subject in an entirely opposite direction, in an entirely opposite spirit; while I admit the scientific side of bird study as valuable within stern limitations, I am dealing with things alive, interesting, beautiful, wonderful, with scarcely an exception, as a whole, valuable beyond all computation, and individuals among them ranking high among my most valued helpful friends. Where it purports to be history, it is real history and while I have been telling of what birds have done for me, I have not dared to tell how much they have done or how great their influence has been. I will fail utterly if I fail to give the personal touch; leaving your hearts unmoved by my portrayal of the adorable little ways of some of my adorable little friends. The only 
magic I have discussed has been the magic of real friendship, my sympathies always on the side of the hunted and always protesting against the killer who killed for fun.

Here is the general law that governs all acquaintance with animate things; from an intimate acquaintance with individuals of a race we arrive at a general acquaintance with all the members of that race. Thinking of members of the human race, for instance, as Japs, Slavs and Orientals, is conclusive evidence that intimate acquaintance with members of those races has not enabled us to sink out of sight the big blur of Nationality. Personality and friendship quickly efface the mere tag of racial distinction and aloofness. We only know them when we know their mentality, their place in the scheme of Nature, their possible comradeship and affection.

John Sawyer, a Jap in my class in the University, whose name we could never learn to pronounce, and so called him that-stands to me for all his race. Intellectually brilliant, gentle, kindly, his personality, over enormous handicaps, carried him forward to popularity, and though none of us had seen his like before, he won the friendship of all. After going back to his own country he wrote me, I presume as a joke, quite a long letter in his own language, not one word of which I 


\section{What Birds Have Done With Me}

have been able to decipher, and I not only still cherish it, but what is more, I never got so much out of any other letter.

I never thought of Robins as a kind of bird bearing that name, but to me they are all the relatives of "Big-Bellied Hen," with whose amazing history I became familiar while still in kilts. Figuratively speaking, I never see a "Cock-Robin" without looking around apprehensively for the "Sparrow with his Bow-and-Arrow." Naturally under these circumstances, I feel that I do well to be angry when the Biological Survey, having charge of the enforcement of the Federal Migratory Law, yawns and asks the time of day when I send them an account of a Negro having in his possession "A Barrel of Pickled Robins." How many doves would it take to mourn for a barrel of dead Robins? Not enough I fancy to reach the ears of the officials at Washington.

Going back to those sheep again. A few years ago I was being taken to a Hospital for an operation that promised one chance of recovery in five thousand and the auto, in which I had been placed to ride from the Station to the Hospital, was stopped almost as soon as we got started, by a vast flock of sheep on their way to the stock yards and the shambles. Their voices awoke ten thousand old memories and I scrutinized each passing face for resemblance to "Nan and Lilly" my two 
first Cosset lambs, and was relieved that there was not a familiar look on a single face. Even here, I was generalizing from "Nan and Lilly," to a personal knowledge of a whole bleating race. It had been the night before when the passing flock of wild Geese right over the house called me back from the coma into which I seemed to be sinking. Dead "Canada" was the leader and was pointing the way to the still waters that would quench my intolerable thirst. Now I might have shot and dressed and cooked a score of Geese, and eaten a different part of each without coming to know a thing worth while about "Canada," "The element of life in God's great picture of Autumn."

Once upon a time (as all true stories begin), we occupied my wife's Uncle's Cottage in Florida, and the Post Master and general merchant in the near-by village, wanting to discharge some obligation to this Uncle, came with guns, dogs, Ponies, and Buck-Board to take me hunting. He certainly had not come because he knew me, and had planned the expedition because he did not know me. We drove directly to an entirely deserted village four miles away, where private information had reached him that game was simply waiting to be killed. And so it proved, for we had not hitched the Ponies in an old shed before he discovered an immense covey of Quail in the rank growth of weeds not ten feet away. He thrust 


\section{What Birds Have Done With Me}

a cocked double-barreled shot gun into my hands and said in a tense whisper: "Give 'em one barrel on the ground and the next, when they get up." I am surprised that I heard him, for, in some unaccountable way, I was back in that Wisconsin swamp where I had helped round up the oxen on that far way June morning, and these tiny feathered things did not look much larger than "Mrs. Stumpy's chicks" and not nearly as wild. For some reason this covey had not been hunted and were unafraid. If very hungry, I might have done it, or if wife or children needed meat, but kill a Bob White, a thing in a wide sense related to "Mrs. Stumpy," for fun; that I could not do. I scarcely remember how I tried to square myself, I know it was no use to try to make him understand, and I was quite willing to have him think me "bug-house."

Only last winter a County official in a Southern City, with an auto, and dogs, and guns, and another mighty hunter, and two women Dianas, pulled up in front of a Drug Store and the host called his father out to see the spoil of a two days' hunt, eighty Bob Whites. The white haired old gentleman, and he was a gentleman, congratulated the party with beaming face, so sorry that he could not have had a hand in the splendid sport. Honestly, I did not understand their feeling any more than they could understand mine while we 
were both looking on the same thing-a string of dead birds. I grant them their point of view, but honestly, had the string been Irish potatoes instead of Quail that they as kitchen police in a Cantonment, during the world war, had prepared for use, by the process called peeling, I would have thought it much more worthy of congratulation.

Somewhere, I have seen a picture of a mighty hunter, with a wide, wide smile on his refined face, and Duck, and Ducks, and Ducks, and more Ducks festooning, smothering his manly form. Of course it was in a saloon, where only moderate drinking is indulged in, and the joyous company is celebrating the grand victory of one of their own number. It was almost like the ovation we give to returning soldiers who have been making the world safe for democracy. I do not see this aggregation of dead things as ducks, but as individual ducks, each with an unknown individuality and personality, with somewhat rudimentary traits and faculties in the main, but with other traits far surpassing human reason, or human sentiment. They are nearly all Mallards and I knew a certain Green-headed Mallard who opened the door into the secret archives of his race. Elsewhere in this volume I have told of "Mally's" mating with a single white Pekin Duck, and it will be easy for these fine gentlemen to under- 
256 What Birds Have Done With Me

stand his loyalty and devotion to his choice of a single mate and perhaps they will take off their hats to world voyagers, even though they have to be taken home by the police, late at night.

The Rose-Breasted Grosbeak on the winter hat of the florid lady, who sits just in front of us at church, is no kind of a teacher of bird lore and I am fully convinced that every florid and devout lady in the congregation might boast the same adornment, the aggregate amounting to quite a little flock, and the flock would leave me in deep, dark and awful ignorance of the things most worth while in the individuality of one of their number. I might even concentrate upon the nearest bird, before and after the prayer and from the opening hymn to the Doxology, without learning that the birds present, in life, could have made that surpliced Choir sound like a Hawaiian Band. Intense concentration upon the possibilities of this bird during firstly, secondly, and thirdly, of the long-winded sermon, might still have left me in shameful ignorance of the fact that this bird, beyond all other birds, has a full-sized appetite for potato bugs. On the other hand, "Mr. Esau" was a living teacher and taught me all I need to know about Grosbeaks, and at the close of the term I was as much fed up with knowledge as he, with White Grubs.

"Mourny" and "Mr. Moses" were my primary 
teachers; "Mr. Waxwing" and "Gooey Bill" helped me through the grades, and the Chickadees and Grackles saw me graduate from High School, and when in College my thesis on: "Yorick" secured for me my degree of B. M.-Bird Man. I am not quite clear on this point, but fancy that I may have been admitted to the Bar, as "The Birds' Attorney" when I used to take "Canada" down to the Lake every day for a swim.

My Father's experience as a teacher had minimized the value to be obtained exclusively from School Books, and he gave us children a large admixture of current reading, including all of Dickens. The characters became real personages to us and we knew them just as well as we knew the people in the near-by village. It's not an exaggeration to say that it would scarcely have surprised any of us children to have turned the corner and come face to face with Daniel Quilp, Sampson Brass, or Miss Miggs, any more than it would have surprised us to have met George Hyer, "Pug Hamilton" and Miss Talker, all residents of the town, whom we knew as well as we knew our own names. Later on, when I went away to school, I heard to my utter astonishment, people discussing Dickens' works in a well-bred and pedantic manner and yet they did not know a single character intimately, and would not have stopped to 
258 What Birds Have Done With Me

listen if they had heard Barnaby Rudge's Raven saying: "I'm a Devil, I'm a Devil, I'm a Devil." The glib talk of volumes, ignoring characters, seemed most vague and unsatisfactory, as though some one was setting up to have acquired a thorough knowledge of China by memorizing the names of all the different kinds of tea grown in that country.

The veil of a temple has been rent and you are being admitted into a Holy of Holies when the barrier of fear between you and forms of wild life is rolled up like a scroll, and you become friends and comrades.

Is it not a shameful thing that man, the image of his Maker, is an object of terror to his little brothers of the field and forest? Among unnumbered monsters, there is nothing else that inspires such universal fear, such a mad frenzy of apprehension. They will complain that they found the game wild. Which is the wilder, the hunted or the hunters? These wild things so relentlessly pursued to their death were naturally tame and full of confidence till man made of himself a "scarecrow"- a shamming presentiment of evil.

In the September "Recreation" there is a picture of a man, sitting on the ground, a grouse perched on his arm. Though often found near human habitations, it is reckoned among our wildest birds. A lonely U. S. mail carrier, in a bit of 
woods, where he halts for dinner and to feed his horse, convinces this shy denizen of the forest that he is no Killer, and in no time they are friends, each born again and each thrilled by the indescribable joy of strange intimacies.

The Canada goose, world voyager of the upper air, a vanishing picture of the day and a weird voice of the heavy night, is commonly regarded as the wildest of all things, and yet after a few weeks of the close relations of surgeon and patient the barrier of fear was broken down and my wild goose would come at my call like a dog. There is no miracle about this. I have simply ceased to stand for the most gruesome, hideous thing in all the Universe of God-an eternal, all-embracing fear.

Some years ago an American writer of books gave one this title: "He Fell in Love With His Wife," and, though I never read the book, I can imagine that the feeling must have been akin to that experienced by the man who starts in to get really well acquainted with a very familiar bird. It's a mutual surprise party, they knew each other so well and yet they did not know each other at all. They had passed the time of day for years, so to speak, but never for a single hour had they paused "to loaf and invite their souls." The man who fell in love with his wife was a worshipper of beauty and his own wife was the most beautiful 
260 What Birds Have Done With Me

woman in the world, but he did not know it. $\mathrm{He}$ was always looking for comradeship and she was the only person who could share fully every thought and feeling that had ever swept his being; his parched lips had been seeking gladness and though he knew it not, her heart was its overflowing fountain. Many a "Sir Galahad" has ridden across the world in search of the Holy Grail, returning old and blind to find it at his own door.

"The poor you have ever with you," do not pass them by for there is a divinity in common things, and to be really acquainted with simple forms of life is more than to dwell in marble halls. Though far from the madding crowd, having found one bird: "a fellow of infinite jest and most excellent fancy," let us be content. 


\section{CHAPTER XXI}

THE UNKNOWN PATHWAY

The poetry of the Book of Job is not only something that takes you back to the infancy of Time, but with its minute insight, into the troubled heart of universal man; it has in it a surge and music touching the sublime. The great story teller with a great epic to relate, stops to gather flowers and comment on facts, minute facts of natural history, and later on incorporates the flower and the fact into the epic, which would not have been so great without them. Listen to this brief statement of natural history and open your ear to the wonder and the strangeness that is opened up by it: "There is a path that no fowl knoweth and which the Vulture's eye hath not seen." The human Air-man in France did not miss many paths, looking from the sky what wonderful opportunities for observation; to say that he missed one would seem to demand explanation. Looking down from above, through all the ages the birds have been watching and acquainting themselves with the paths made by terrestrial crea- 


\section{What Birds Have Done With Me}

tures. Nevertheless, there is one that they have not known. Science has not apprehended the sweep of the Vulture's eye. Instruments for measurement have been wanting, baffling mists intervene between the bird in the sky and the thing that he alone sees distinctly. Did you ever carefully scan the sky from the deck of a ship with a good glass and be unable to find a glimpse of a far off wing, and then cast your bread upon the water and have white-winged things dine upon it before you were out of sight? The sight of the Vulture is presumably first of all, but there is a path that he hath not seen. Here is the poetry hiding behind the fact, the something unknown, the something unseen.

Nearly, a quarter of a century ago at the Maplewood, on Green Lake, the usual peace and quiet of the place was changed into the wildest commotion by the sudden disappearance of the only daughter of the home, a child of four years of age. It was late April and the lawn was green and the Lake sparkling in the sunshine, but it was capable of laughing on in merry glee after swallowing tender innocence; and when she could not be found elsewhere, a thousand hideous apprehensions all pointed to the Lake. These were dispelled when the shepherd came over the hill beckoning wildly, the lost one both figuratively and literally was safe in the fold. There we 
found her perched on the fence, screaming with delight over the astounding gambols of the band of young lambs. She was quite uncomprehending of any alarm on her account. The cow-yard was between the house and the sheep-yards; she could not have crossed the first, with its forty head of cattle; how had she reached the second? The only statement made was one to which she stoutly adhered: "The chickens showed me the way." This was an incident never likely to be forgotten, especially by a father who had been led into strange regions by feathered things.

What a weird and wonderful pathway it has been, invisible except as indicated by fluttering wings, every future step hedged about and impenetrable, the past shining, sun-kissed, golden. Little did the bare-footed boy realize when he stepped into that first soft moist furrow that he had started on a life journey over that hidden pathway that no fowl knoweth and which the Vulture's eye had not seen. I saw a picture the other day of an enormous Spider's Web catching and holding little creatures and letting the big ones escape. What are big and what are little? Does size indicate values? We need a revaluation. A little peach is of more value than a big turnip. A golden apple than a golden pumpkin. A tiny diamond than a great boulder. I am so afraid that we cannot get together on the matter of 


\section{What Birds Have Done With Me}

values. You want to show me your fat steers and pigs and bursting granaries and long corncribs, and perhaps your bonds and mortgages, for which you have exchanged all the days of your lives, and when it's too late to be happy, you are saying, "Soul, thou hast much goods laid up for many days," and before you have finished the complacent boast, mean old death is knocking at the door, to tell you that the census taker Time has put you on his list.

What shall a man get for a wasted life, eyes self-blinded to flowers and waterfalls, rainbows, sunsets, and stars; ears self-stopped to winds and waves, and wild bird music? Oh! brother mine, I have not been able to tell you before, but for a fact, I have stood upon the golden hills of dawn close by your side, and while you have prattled of your vast wealth my heart has been bursting with compassion over your indescribable poverty, only counterfeit dollars that will buy nothing. These fat fellows slap me on the back and ask with well-assumed interest, if I have to engage a lawyer to make out my income-tax schedule. It's one of the best jokes in the world for we both enjoy it equally. They think I have no income and I feel certain that if the hat was passed around in a congregation of church mice, for their benefit, the offering should be large.

Let me see, the unknown pathway first of all 
led me into a society of aristocrats, some blue coated, nearly all blue blooded, and each with their own tree. What a big circle it was. If I had been the Bishop of their souls, I could not have made a pastoral call on each one once in ten years. Some, that I knew first in the chart class, I later on knew as fathers and mothers, grand-fathers and grand-mothers, and as great grand-fathers and great grand-mothers, uncles, aunts and cousins without end.

Some birds that I have known, had an individual acquaintance with, would reach into the hundreds, possibly, up to the thousands, and all have been more or less captivating friends. Human friends drop in to dinner when there is nothing to eat in the house, come and find you shaving and instantly want to try your razor, only to find that you don't know how to strop a razor, and yours should have been junked years ago. Everything but your toothbrush you hold in common with your friends; and one may not look in the direction of five and ten dollar loans for in that direction apoplexy lies. Boredom is one of the unmitigated curses from which there is no escape in the best society, unless that society is composed of birds' friends.

There are people whom we play host to in the way that a horse plays host to a gad-fly and sometimes soul-savers come and want to pray, when 
all out of doors is fairly bathed in the benediction of "Mighty God." The Bird Kingdom is free from our conventional abuses and there climbers excite neither envy nor disgust. Excusing considerable digression, we come back to the real unhampered joy of bird friends where relations are cordial but never too intimate.

Without being too personal I have been telling you about some of these friends in earlier chapters. I have not really attempted to tell you how strong has been my attachment to some of these close friends, for has not the great poet of humanity, Shakespeare, warned us that "I would love but little if I could tell how much."

Following along the unknown pathway not only led me to the birds themselves, but into that great department of our literature that pertains to birds, rich, ample, and of absorbing interest. What a surprise it was to find the trails blazed from an early day, Aristotle and Pliny being voluminous writers on the subject and a part of it being good natural history today, the rest of a character that even Herodotus would have chronicled as having been a rumor over in Ethiopia. For years, we were not occasional callers at the homes of Frank M. Chapman, Mabel Osgood Wright and Neltje Blanchan, but steady boarders, and according to the customs of rural school teachers, in an early day, we boarded around, and Chester 
A. Reed was a pocket piece. "Nature Study and Life" by Clifton Hodge, we fed to boys on Saturdays around camp fires. This same unknown pathway led me to the splendid pioneer work on the "Economic Value of Birds" by Prof. F. H. King, of the University of Wisconsin, unhappily immured in a big volume on Geology and thus kept out of general use.

Again the unknown pathway led to John o' Birds and John o' Mountains, Burroughs and Muir. With John Burroughs we wandered and lost our way, came back and started in again for more little journeys in the wilderness of our settled and cultivated States. Going afield with others, you scarcely get beyond the sound of rural life, bleat of sheep and low of kine, where Chanticleer not only salutes the Dawn, but makes vocal the passing hour; but "John o' Birds" takes you where Dryads glide and Pipes of Pan are heard where:

"Long lights shake across the Lake

And the wild cataract leaps in glory."

With "John o' Mountains" we climb dizzy heights, and cross impossible crevasses, sharing the wild rapture of "Stickeen" and Muir it is that shows us a dandelion and dear homey Cock Robin cuddled up close together on his very own glacier. My daughter and $I$ are agreed that no other 
268 What Birds Have Done With Me

water in this world has such a sparkle or can come near to quenching all thirst as that from the Muir deep well that his childish hands chiseled from the rock at the family home near Pardeeville, Wisconsin. And from the same associations, a Loon on "Fountain Lake" becomes one of the sweet singers in Israel. What a calamity to have lived and have passed out of life without knowing and feeling real kinship with two such splendid unspoiled men. Only yesterday, I was introduced to a gentleman, whose home is in California and whose income tax this year will have to be expressed by at least six numerals. Wanting to take his measure, I asked: "What do you know of John Muir?" The name was shrouded by a certain mist and at first I had a feeling that he was trying to run it down in "Bradstreet" so I added, "He was something of a nature-lover." Then the light dawned, "Oh! yes, I know about him, we have a Prune named after him." Mr. Croesus-you poor beggar.

Long before the war, long before it had entered into the heart of Woodrow Wilson, to conceive of his magnificent project of a League of Nations, William Dutcher had conceived of a magnificent project of a Nature League, uniting sportsmen, plume-wearers and all real NatureLovers in a great Audubon League, for the protection of our vanishing wild life. I would insti- 
tute no comparison between Woodrow Wilson and William Dutcher, because in my estimation one does not stand a quarter of an inch higher than the other, and not knowing which is the older, I am not prepared to say which should stand godfather for the other. Dutcher's League aims at the preservation of vegetation, upon which life depends, by saving the birds the natural check on insect hordes, which menace all growing things and consequently life itself. Wilson, by his League, would preserve Justice and Freedom and hold in check ignorant hordes that threaten Civilization. These sages, seers, stand upon the mountain top and whatever the surprises of the future, the world will not soon look upon their like again.

The unknown pathway led me into Audubon work. Some addresses made for the Agricultural Department of the State University led to my being selected as Secretary and Treasurer of the Wisconsin Audubon Society, which put me on the firing line for bird protection. The work opened out more and more, and there came into my horizon, such men as J. Gilbert Pearson, the gifted and efficient Secretary of the National Association of Audubon Societies, a veritable Pershing in our army of bird protectors, and Dr. Theodore S. Palmer, of the Biological Survey, that astute strategist and indefatigable worker, the silent 


\section{What Birds Have Done With Me}

partner in all legal firms having anything to do with bird protection, and William Hornaday, reincarnation of General Grant, the live wire of the National Museum of Natural History, whose "Vanishing Wild Life" has done more than all other writings combined to reveal the brink of the pit over which bird life trembles. His book, a paper automatic, has done more to silence machine guns in the hands of sportsmen than another man might have done with a bird cannon. At a game warden school, held in Madison, Wisconsin, I know to my certain knowledge, that two thirds of the Game Wardens joined the Audubon Society and arranged to purchase "Our Vanishing Wild Life" as fixed ammunition to be carried in their kits. The very best letter ever written me was received, soon after that school, from one of the wardens, full of enthusiasm and anxious to do "something for the little birds." The letter was addressed to "The Birds' Attorney" and signed "John Eagan, your Office Boy."

The unknown pathway led to a lecture field that covered much of Wisconsin and part of Mississippi, and articles on birds for the public press and letters without end. Among bird workers in Wisconsin, Prof. A. H. Burrill and E. A. Cleasby deserve special mention. Wisconsin bird-lovers can never pay the debt they owe these splendid workers, who are both out of the State and whose 
places it will be difficult to fill. The Biological Survey in Washington got Cleasby, and Burrill finally went West, but not till he had done yeoman's service in helping the writer in securing Bird Sanctuaries aggregating more than sixty-five thousand acres, throughout the State. Generous, bighearted Dr. A. M. Benson must come in for due credit in having donated a full page in the Wisconsin Humane Herald for Audubon work after "By the Wayside," the organ of the Society, had died a natural death. W. W. Cook, formerly of Ripon, Wisconsin, and later on of Washington, D. C., aided by Prof. Mitchell, of the Milwaukee Normal School, did valuable Bird Work, in which our State had a special interest.

Among the fine Nature Books written by Gene Stratton-Porter, her "Birds of the Bible" stands out in my recollection as having been especially interesting, for it furnishes evidence that an instructive volume can be written, not only on birds mentioned in the Bible, but on those mentioned in Shakespeare and the beauty of much poetry would be utterly destroyed, were we to attempt to eliminate all references to birds. Poetry without its birds, would be as silent and desolate as the coming of spring in the Northland without its returning migrants-its very life, melody and gladness.

Through more than a half century of reading, 
272 What Birds Have Done With Me

the flutter of a bird's wing has opened a window for me to the wide, wide sky. Friends from everywhere have been clipping and sending me notices of birds appearing in the daily press, and if old Santa Claus found himself at my door with no bird book in his pack for me, I have a notion that he would feel that he had overlooked something. Mine is a bird world and I could not live in any other. They are surely my birds for am I not the "Bird Man" and "The Birds' Attorney"? A Telephone Company once offered me a hundred dollars if I would allow them to clean up a hundred rods of trees and shrubs and vines and wild roses growing along a public road near their poles. It greeted me "sair" to have to assure its field man that I no longer had title through adverse possession, the birds in more than twenty years had gained that, and as their legal representative, the best I could do would be to act, if he secured their consent in writing. Not two minutes ago a hardened coquette, aged three, perched on a gatepost, called me, a mere passing acquaintance, to her and whispered, "I seem to care more for you than for any body else." Following the example of my youthful admirer, I want, in the strictest confidence, to whisper into the big ear of the public: "I seem to care more for some birds than for some people and I don't care if I do."

Again I feel the lure of the pathway that no 
fowl knoweth and which the Vulture's eye hath not seen. Is it not the wondrous pathway across the sky, the unmapped, uncharted highway used by the unnumbered billions of migrants that with the changing seasons, spring and fall, have gone back and forth, leaving no trace behind? I am writing these last words here in Dixie Land and from my window I can see the Purple Martins just demobilized from the advanced guard of migrants and the mighty urge is being born again. What matter if I go ahead or follow? I am going back home with the birds, my singer, my song, but yours as much as mine, if you will open your heart to the singer and the song.

What means Alfred Tennyson by saying:

"Ah! sad and strange as in dark summer dawns

The earliest pipe of half-awakened birds

To dying ears, when unto dying eyes

The casement slowly grows a glimmering square."

A recognition of "The earliest pipe of the half awakened birds" will banish the strangeness and do much to eliminate the sadness and "While the casement slowly grows a glimmering square" to dying eyes, dying ears may hear in these pipings, the first faint notes of the choir invisible.

In very fact, the bird-lover, on the wings of 
274 What Birds Have Done With Me

the birds he loves, is carried upward, where Alps on Alps arise to far altitudes, that he never could have reached alone. 

RETURN TO DESK FROM WHICH BORROWED

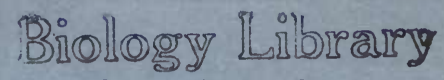

This book is due on the last date stamped below, or on the date to which renewed.

Renewed books are subject to immediate recall.

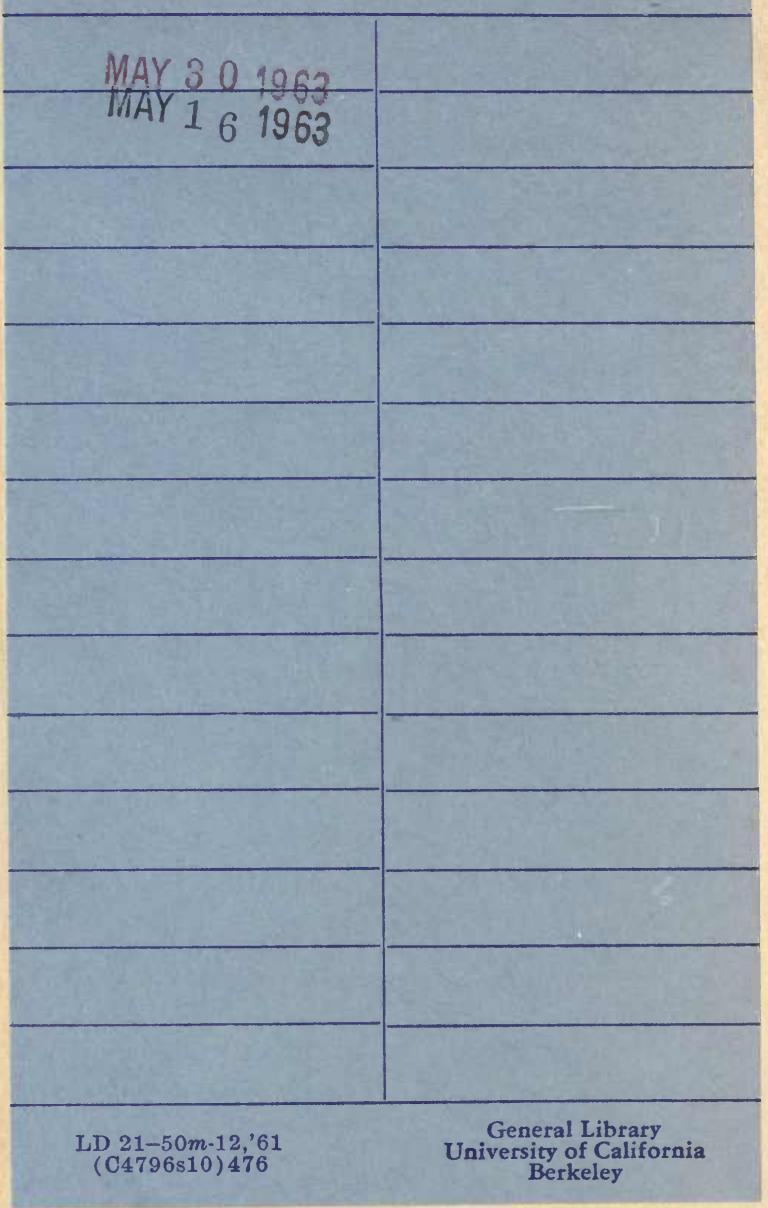



